Portland State University

PDXScholar

Master of Environmental Management Project

Reports

Spring 2015

\title{
The Blue Heron Wetland Restoration Project: \\ Eradication of Ludwigia peploides ssp. \\ montevidensis from the Blue Heron Wetlands of \\ Portland, OR
}

Alexander Staunch

Portland State University

Follow this and additional works at: https://pdxscholar.library.pdx.edu/mem_gradprojects

Part of the Environmental Indicators and Impact Assessment Commons, and the Natural Resources Management and Policy Commons

Let us know how access to this document benefits you.

\section{Recommended Citation}

Staunch, Alexander, "The Blue Heron Wetland Restoration Project: Eradication of Ludwigia peploides ssp. montevidensis from the Blue Heron Wetlands of Portland, OR" (2015). Master of Environmental Management Project Reports. 47.

https://pdxscholar.library.pdx.edu/mem_gradprojects/47

https://doi.org/10.15760/mem.46

This Project is brought to you for free and open access. It has been accepted for inclusion in Master of Environmental Management Project Reports by an authorized administrator of PDXScholar. Please contact us if we can make this document more accessible: pdxscholar@pdx.edu. 


\title{
The Blue Heron Wetland Restoration Project: Eradication of Ludwigia peploides ssp. montevidensis From the Blue Heron Wetlands of Portland, OR
}

\author{
Project Report: April 2015 \\ Prepared By: \\ Alex Staunch \\ Portland State University \\ Portland, OR 97201
}

A report submitted in partial fulfillment of the requirements for the degree of Masters of Environmental Management at Portland State University

Project Partner:

East Columbia Neighborhood Association

\author{
Project Committee: \\ Mitch Bixby \\ Tom Griffin-Valade \\ Dr. Joseph Maser \\ Dr. Mark Sytsma
}

The Department of Environmental Science and Management Portland State University

2015
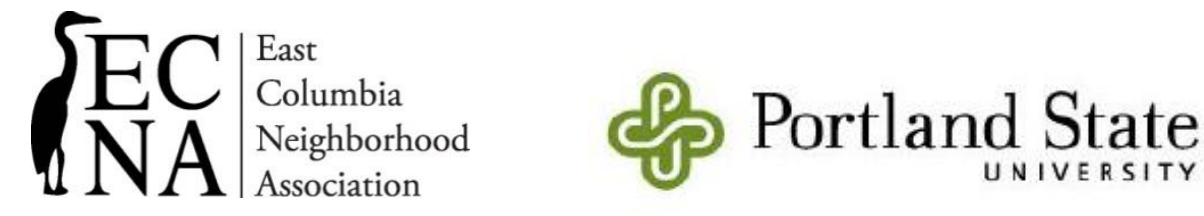
Final Draft: April, 2015 
Table of Contents

\section{Executive Summary}

\section{Introduction}
A. Purpose and Need
B. Management Goals
C. Biology and Impact of L. peploides
D. Identification of $L$. peploides
E. Site Description
F. Project Establishment \& History

III. Control Methods
A. Herbicide Efficacy Pilot Test
B. Herbicide Application
C. Hand Removal
D. Seeding
E. Disposal of Biomass
F. Stewardship Program

IV. Monitoring Methods and Results
A. Herbicide Efficacy Pilot Test

1. Methods

2. Results

B. Plot Analysis

1. Methods

2. Results

C. Range and Density Mapping

1. Methods

2. Results

V. Outreach
A. East Columbia Residents
B. Scientific Community
C. Volunteer Activity

$\underline{\text { Page }}$

$\underline{\text { Page }}$

2

VI. Lessons Learned

36

\section{4}

4

5

6
VII. Future Action

VIII. Misc. Work Completed

IX. Budget and Expenses 48

$\mathrm{X}$. Acknowledgements $\quad 50$

XI. References

XII. Appendices 55

A. Acronyms 55

B. Planting List 56

C. Select Plot Photographs 57

D. Select Monitoring Photographs 67

E. Scientific Presentations 69

F. Expenses by Category $\quad 70$

G. Common Open Space Agreement 71

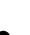




\section{EXECUTIVE SUMMARY}

The Blue Heron Wetland Restoration Project (BHWRP) is an ongoing community driven effort to eradicate Ludwigia peploides ssp. montevidensis from a 3.5 acre ephemeral wetland in Portland, OR. Established in summer 2011 by the East Columbia Neighborhood Association (ECNA), the BHWRP consisted of an herbicide efficacy pilot study, widespread eradication effort, and establishment of a stewardship program. Ludwigia peploides ssp. montevidensis is an emerging threat to northwestern Oregon and the infestation within the Blue Heron Wetlands (BHW) represented one of the first known infestations of L. peploides ssp. montevidensis within the State of Oregon.

First observed within the BHW in 2004, L. peploides ssp. montevidensis rapidly colonized 2.4 acres of wetland habitat, reduced native floral diversity and minimized resources for wildlife. In fear of continued impact to wildlife and increased likelihood of wetland flooding, an integrated pest management strategy involving chemical and manual removal was implemented to eradicate $L$. peploides ssp. montevidensis from the BHW. The initial pilot study of 2011 tested glyphosate and triclopyr at relatively low concentrations within the wetlands. The herbicide mixes of $1 \%$ triclopyr and $0.75 \%$ glyphosate did not significantly reduce percent cover of L. peploides ssp. montevidensis. To improve results of L. peploides spp. motevidensis control, an increased concentration of $3 \%$ glyphosate was applied to the infestation on September 26, 2012 and August 8, 2013. The entire population was then hand pulled in 2013 and 2014.

Application of 3\% glyphosate provided adequate control to populations of L. peploides ssp. montevidensis that were flowering at time of herbicide application. The fall application of 2012 reduced the density of L. peploides ssp. montevidensis within the central region of the wetlands where flowering occurred later in the season due to perennially saturated soils. Populations along the wetland perimeter that flowered and went dormant early in the season in response to drying soils returned at high densities 
in the coming year. The early August 2013 application and following hand removal events greatly reduced the range of L. peploides ssp. montevidensis within the BHW by a total of $76 \%$. Within the BHW 3\% glyphosate application was most effective as a systematic herbicide when applied as close to the time of flowering as possible and prevented further additions to the local seedbank. Hand removal insured surviving individuals were quickly removed and prevented plants from quickly increasing in biomass.

Outreach and education carried out by the BHWRP successfully identified and trained a core group of East Columbia residents to carryout long-term management of the L. peploides ssp. montevidensis infestation. The community led effort generated over $\$ 43,300.00$ in volunteer labor and in-kind donations since project establishment. Average costs for chemical application, hand removal and wetland seeding was $\$ 3,906.59$ per acre from 2012 to 2014 . For financial support, the ECNA has secured funding for further hand removal events into 2016, in attempts to reach the initial goal of complete L. peploides spp. montevidensis eradication.

This document is meant to summarize the "past, present and future" of the BHWRP. The report was written to be utilized by local land managers as well as educated citizens of the East Columbia Neighborhood. Work completed within the Blue Heron Wetlands was pioneered by passionate residents of the East Columbia Neighborhood and made possible by the support of local agencies, organizations and institutions. The April, 2015 Project Report contains material adapted from previous written work of the BHWRP (Staunch, 2014; Staunch et al. 2011). 


\section{INTRODUCTION}

\section{A. Purpose and Need}

Observed as 'transformer invaders' as defined by Richardson et al. (2008), non-native representatives of the Ludwigia genus reduce native plant diversity, slow water circulation, increase sedimentation rates, negatively affect native fauna and alter water chemistry within introduced sites (Dutartre, 1988 cited from Dandelot et al. 2005; Sears et al. 2006; Stiers et al. 2011; Thouvenot et al. 2013a). The presence of the invasive macrophyte, Ludwigia peploides (Kunth) Raven ssp. montevidensis (Spreng) Raven within the Blue Heron Wetlands (BHW) of northeast Portland, Oregon impeded functionality and reduced biological diversity of the wetland system. The invasive weed hindered the ability of the wetland to carry out the designed functions of flood prevention and pollutant filtration for residential run-off from the East Columbia Neighborhood. Native plant diversity decreased and open water habitat for waterfowl, reptile and amphibian species was greatly reduced. Furthermore, the hydrologic connectivity of the BHW, posed a threat for further spread of L. peploides ssp. montevidensis into the adjacent drainage system, the Columbia Slough and the Lower Willamette and Columbia River systems (Josh McNamee, pers. comm., July 2013).

Representatives of the Ludwigia genus are currently increasing in prevalence throughout the State of Oregon, with a rapid rate of spread occurring in the Willamette Valley. Within Multnomah County, Ludwigia spp. are known to have colonized various wetlands, small ponds, irrigation ditches, the Columbia Slough, main stem of the Willamette River and the Multnomah Channel (Alex Staunch, personal observations). The State of Oregon has designated the exotic L. peploides ssp., L. hexapetala (Hook. \& Arn.) Zardini and L. grandiflora (Michx.) Greuter \& Burdet as Class B noxious weeds (Oregon Department of Agriculture, 2011a). As a Class B noxious weed, Ludwigia spp. are regionally abundant to a degree that a fully integrated statewide management plan is not feasible, but intensive 
management is still encouraged on a case-by-case basis (Oregon Department of Agriculture, 2014).

Within Oregon, Ludwigia spp. are widely distributed in Linn and Benton Counties with limited distribution in Multnomah and Lane Counties (Oregon Department of Agriculture, 2011b). With the increasing presence of Ludwigia spp. in the State of Oregon and their classification as being economically significant, swift action was taken within the BHW to prevent further introduction and establishment of L. peploides ssp. montevidensis in the waterways of Northwestern Oregon.

The Blue Heron Wetland Restoration Project (BHWRP) was established in 2011 to reduce the impact of L. peploides ssp. montevidensis within the BHW. Generous fiscal contributions were allocated to the BHWRP in the form of grants from East Multnomah Soil and Water Conservation District (EMSWCD), Intel, Metro and North Portland Neighborhood Services (NPNS). A second Nature in Neighborhoods Grant from Metro was awarded in fall of 2014 to allow continued control and monitoring until 2016. Results from control strategies within the BHW for L. peploides ssp. montevidensis have been quantified and presented in this document in hopes that the lessons learned from the BHWRP will be applied by local land managers in future eradication attempts of Ludwigia spp.

\section{B. Management Goals}

The long-term goal of the BHWRP is complete eradication of L. peploides ssp. montevidensis from the entirety of the BHW. Here, eradication is defined as no growth occurring within the wetlands for a period of five years. Continued annual monitoring and appropriate follow-up treatments must occur in order for this goal to be achieved.

The short-term goal was to significantly reduce the range of Ludwigia peploides ssp. montevidensis by $50 \%$ after each year of control and to remove all dense areas of infestation (>50\% cover) by 2014. A secondary goal was to assess the efficacy of selected herbicide mixes in the control of Ludwigia peploides ssp. montevidensis and to report findings throughout the life of the project. Progress 
in range and density reduction was assessed by use of GPS to record changes in cover from year to year. Assessment of herbicide efficacy was achieved through a field study within the BHW.

Short-term reduction and long-term eradication will help prevent additional infestations in the Portland area. It was anticipated that the removal of L. peploides ssp. montevidensis would increase foraging habitat for avian, amphibian and other wildlife populations. Native vegetation already present and those introduced through artificial planting and seeding, would re-establish in areas that the eradicated weed once occupied, further increasing the ecological value of the system. Reduction of $L$. peploides ssp. montevidensis in the wetlands would slow sedimentation rates and reduce the likelihood of flooding in the East Columbia Neighborhood, while improving aesthetics with the expected increase of avian visitors.

\section{Biology and Impact of Ludwigia peploides}

The Ludwigia spp. invasive to Oregon are members of the section Oligospermum known for polyploidy and morphologic plasticity (Wagner et al. 2007; Zardini et al. 1991a; Zardini et al. 1991b). Ludwigia peploides ssp. montevidensis, or floating aquatic primrose willow, is an emergent aquatic perennial in the evening primrose family (Onagraceae). Native to

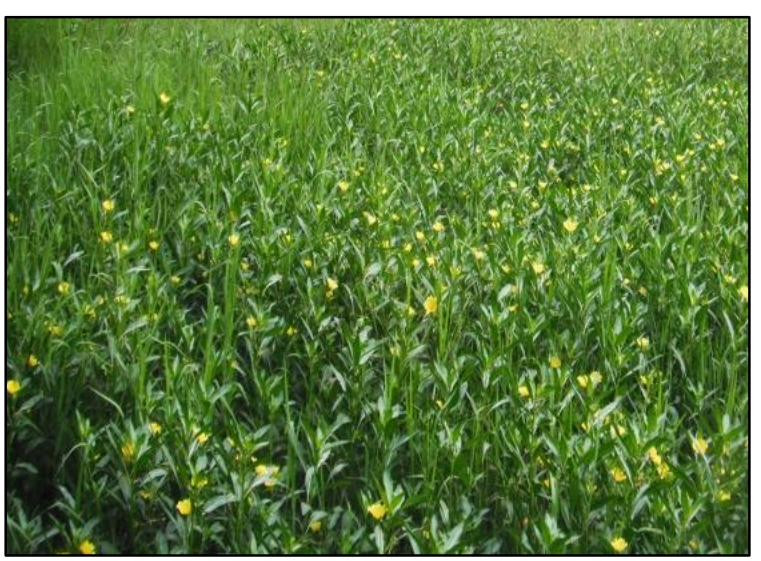

Pic 1. L. peploides ssp. montevidensis competing with knotgrass (Paspalum distichum) in the BHW.

South America, L. peploides ssp. montevidensis is a problematic weed to lakes, ponds, streams and wetland areas in introduced ranges of North America and Europe (Dandelot et al. 2005). In the Western United States, densities of L. peploides range from 500 to $700 \mathrm{~g}$ dry mass (DM) $\mathrm{m}^{-2}$ (Rejmankova, 1992), while L. peploides ssp. montevidensis has been recorded growing in densities up to 7,000 g DM $\mathrm{m}^{-2}$ in France (Dandelot, 2004, cited from Lambert et al. 2010). The growth rate of the associated 
subspecies of L. peploides can reach $50 \mathrm{~g} \mathrm{DM} \mathrm{m}^{-2} \mathrm{~d}^{-1}$, doubling in biomass every 15 to 90 days depending on water velocity and other environmental conditions (Dutartre et al. 2005, cited from Thouvenot et al. 2013a; Rejmankova, 1992). Such a vigorous growth rate and high density result in impacts such as: hyper-sedimentation, decreased flow rates, drastic declines of native biodiversity and hypoxia (Sears et al. 2006; Stiers et al. 2007; Thouvenot et al. 2013c). Ludwigia spp. have been found to facilitate secondary invasions through the translocation of oxygen from the water column to anoxic soils through diffusion of gases by the floating aerenchymous roots (Thouvenot et al. 2013c). Ludwigia peploides ssp. montevidensis also competes allelopathically, by reducing the germination of other wetland species through means of waterborne chemical compounds (Dandelot et al., 2008). Furthermore, L. peploides can potentially alter microbial communities within aquatic systems by emitting anti-bacterial compounds (Smida et al. 2015). These competitive interactions allow $L$. peploides ssp. montevidensis to form dense mats on exposed mud flats and monocultures in open water areas that can exceed two meters in depth (DiTomaso and Healy, 2003; Lambert, 2010).

Ludwigia peploides ssp. montevidensis is able to reproduce both sexually and vegetatively via fragmentation. Ludwigia peploides is the only species of the three invasive representatives of the Ludwigia genus that is self-compatible and does not require outcrossing to produce viable fruiting bodies (Dandelot et al. 2005). The self-compatibility of L. peploides ssp. montevidensis results in a high rate of fructification and production of over 10,000 seeds $\mathrm{m}^{2}$ (Saint-Macary, 1998, cited from Dandelot et al. 2005). Seed viability of L. peploides under experimental settings was determined to be $77 \pm 23 \%$ (Ruaux et al. 2009). The abundant and highly viable seeds migrate though waterways by floating fruits that retain buoyancy for over two weeks, able to move vast distances within moving water systems (Ruaux et al. 2009). Vast seed production and capability of seed transport increases the probability of regrowth and re-establishment after initial control is implemented. 


\section{Identification of Ludwigia peploides}

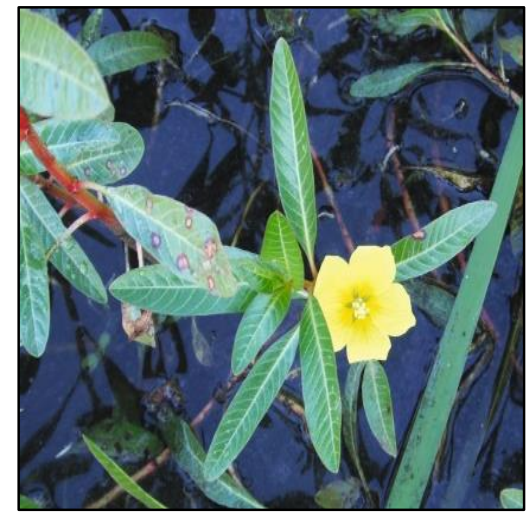

Pic 2. Bright yellow flower and willow like leaves of $L$. peploides ssp. montevidensis
Physical characteristics of $L$. peploides ssp. montevidensis can vary extensively due to the natural plasticity of the species in response to environmental conditions (Hussner, 2010; Thouvenot et al. 2013b). The most identifiable characteristics of Ludwigia peploides ssp. montevidensis are the alternating, round to oblong, dark green leaves and bright-yellow terminal flowers (Picture 2). The leaves tend to be round when young, becoming longer and more willow-like during maturity. The rhizoid stems can exhibit a distinct reddish-purple color (Zotos et al. 2006). Petals can range in number from four to six (usually five) and reach $22 \mathrm{~mm}$ in length (Hoch and Grewell, 2012). The fruit is a cylindrical capsule reaching lengths of $32 \mathrm{~mm}$. White, puffy aerenchymous roots protrude from the stem and float vertically upwards extracting oxygen from the water column.

Due to the different invasive representatives of Ludwigia being similar in appearance, proper identification is the first step in controlling Ludwigia infestations within Northwestern Oregon. Locally, the Ludwigia genus is represented by the native L. palustris (L.) Elliott, or marsh seed-box. The species exhibits much smaller, opposite leaves and inconspicuous flowers that are borne on the leaf axils. Flowers of L. palustris do not possess petals, but four milky-white to green sepals (Hoch \& Grewell, 2012).

Besides the subspecies L. peploides ssp. peploides, the other invasive representative of Ludwigia present in Oregon is L. hexapetala. Ludwigia hexapetala and L. peploides are very difficult to distinguish from one another, with many morphological characteristics overlapping across regions of plasticity (Zardini et al. 1991b). The feature most predominantly used by local land managers to 
distinguish $L$. hexapetala and $L$. peploides ssp. from one another is the different appearance of the bracts at the base of the flower and fruit body (Figure 1A.) (Alex Staunch, personal observations).

The bracts of $L$. hexapetala are lanceolate and elongated (Figure 1B.), while L. peploides ssp. possess deltate shaped bracts (Figure 1C.) (Hoch and Grewell, 2012). Individuals of L. hexapetala gathered from Longview, WA, possess pubescent erect stems, sepals and fruiting bodies in comparison to the glabrous to spreading-hairy stems, sepals and fruits gathered from representatives of L. peploides within the BHW (Figure 1). While visual identification may be possible, proper identification requires a chromosome count.
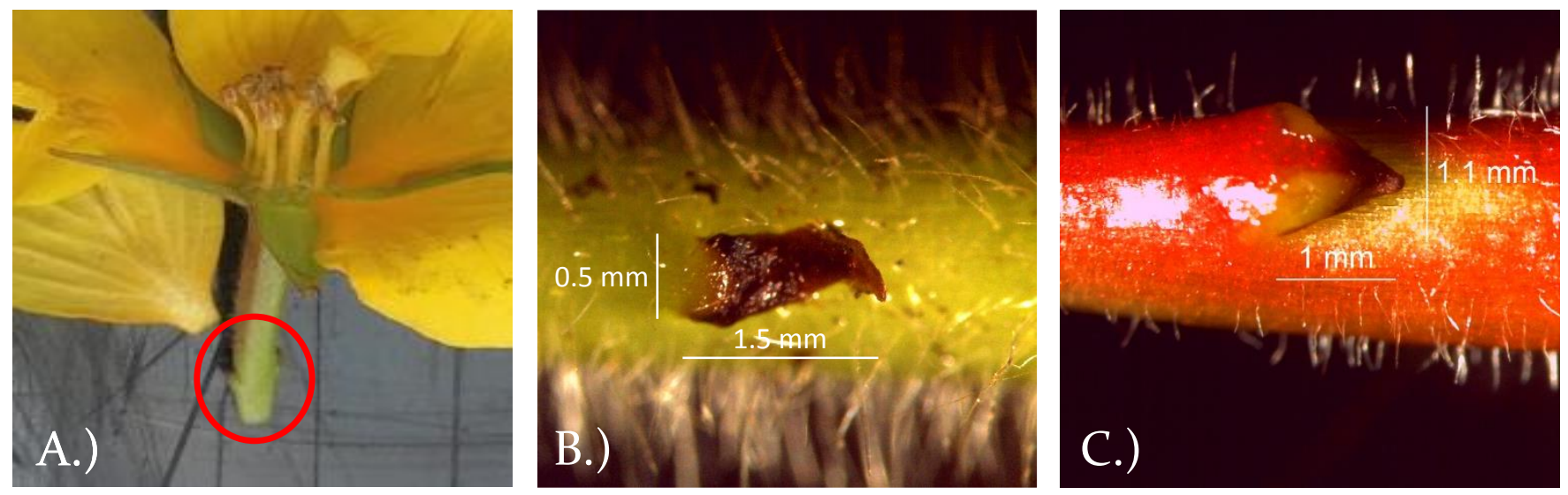

Figure 1. Location of bracts at base of L. peploides flower, circled in red (A.). Bracts of $L$. hexapetala (B.) demonstrate a lanceolate shape and $L$. peploides ssp. montevidensis (C.) exhibit a deltate form. Samples of $L$. hexapetala were gathered from Longview, Washington $\left(46.16426^{\circ}, 123.01135^{\circ}\right)$ on July 15,2014 . Ludwigia peploides ssp. montevidensis were collected from the Blue Heron Wetlands on July 22, 2014.

Of the 82 species within the Ludwigia genus, the Oligospermum section represents 12 taxa known for varying levels of polyploidy (Raven \& Tai, 1979; Wagner et al. 2007; Zardini et al. 1991b). The Ludwigia genus possesses a base chromosome count of eight (Raven \& Tai, 1979). All three species of Ludwigia on ODA's noxious weed list are present within the Oligospermum section and are represented by different degrees of ploidy. Ludwigia peploides ssp. are diploid $(2 \mathrm{n}=16)$, L. grandiflora is hexaploid $(2 \mathrm{n}=48)$ and L. hexapetala is a decaploid $(2 \mathrm{n}=80)$ (Zardini et al. 1991b). Somatic chromosome counts can be carried out with the methods used by Zardini et al. (1991b) and at times 
chromosome counts are the most reliable method for identification (Thouvenot et al. 2013a; Zardini et al. 1991a).

\section{E. Site Description}

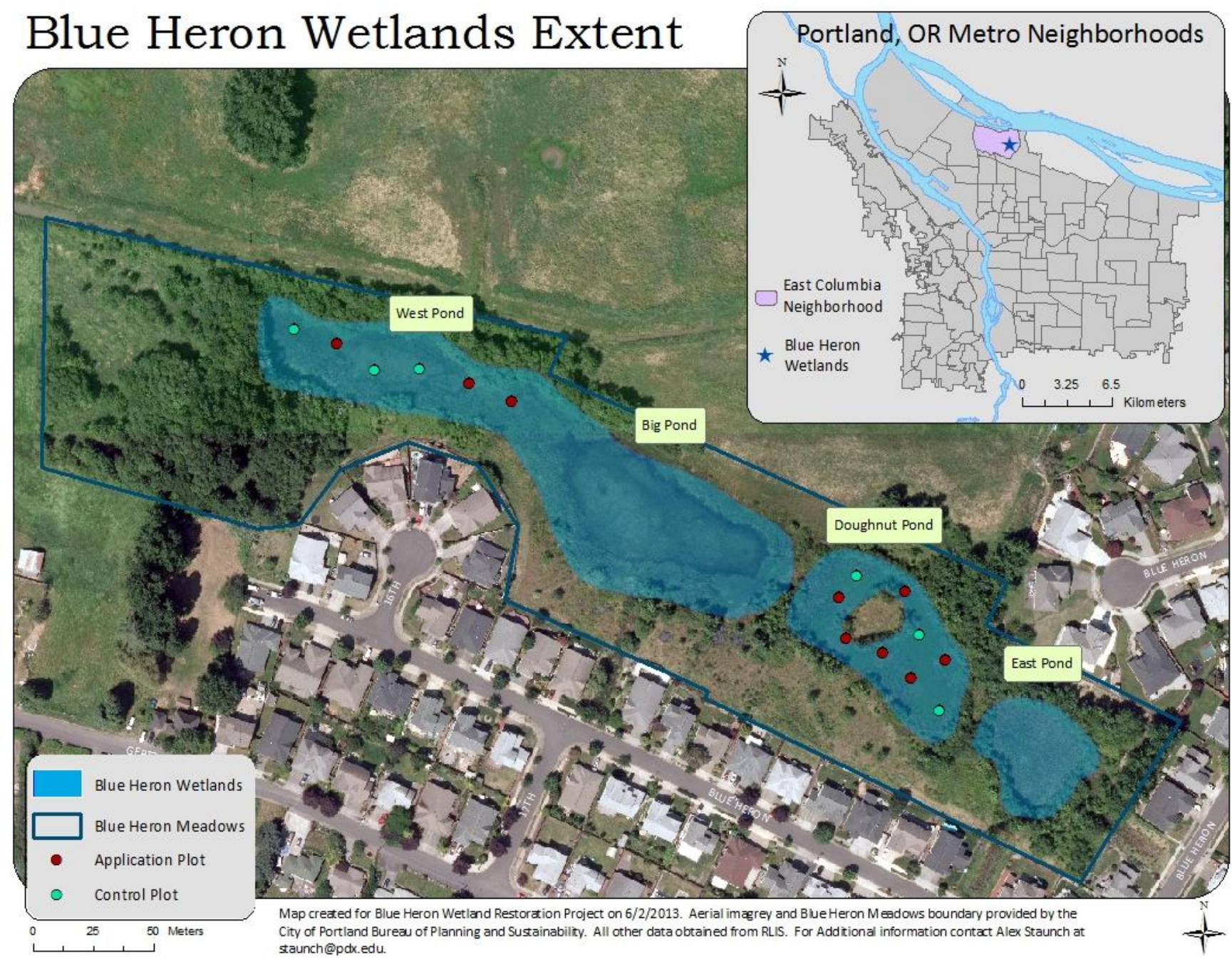

Figure 2. Location of the Blue Heron Wetlands and the East Columbia Neighborhood. Points represent plots in accordance with chemical efficacy monitoring.

Located in the East Columbia Neighborhood of Northeast Portland, Oregon (45.5914306 ${ }^{\circ}-$ $\left.122.6473250^{\circ}\right)($ Figure 2$)$, the BHW is a 3.51 acre wetland complex, preserved and augmented in 1999 to compensate for the construction of the adjacent housing development located in the ancient Columbia River Floodplain. The total property, known as "Blue Heron Meadows" is 10.67 acres in size, which include five bioswales that are maintained by the City of Portland. The BHW mitigate flooding and 
preserve important wetland habitat. Prior to entering the wetlands, surface run-off from the surrounding developed area is treated within the bioswales. Water levels are controlled by an adjoining flood system of irrigation ditches and levees. During flood stage, water from the wetlands flows into the adjacent irrigation ditches and is then pumped into the Columbia Slough by the Multnomah County Drainage District (MCDD). Precipitation and surface runoff account for the major water inputs into the BHW. Conditions within the BHW are highly seasonal, due to the temperate oceanic climate indicative of dry, warm summers and damp, mild winters (Trewartha, 1968). These climatic conditions result in high water levels in the winter and complete drying in parts of the BHW during the summer.

The BHW is composed of four distinct ponds that are hydrologically connected by surface flows at flood stage. Individual ponds were named by East Columbia residents during previous work within the wetlands. Donut Hole Pond (DP) is ephemeral, experiencing dry conditions by mid to late August. DP is circular, 0.73 acres with a maximum depth of 0.75 meters. Western Pond (WP) is rectangular, 1.02 acres and reaches a maximum depth of 0.60 meters. For most of the year WP is hydrologically connected to "Big Pond" (BP) via surface water, but disconnects in late-July becoming completely dry by mid to late-August. BP is the largest and deepest pond within the wetlands. At 1.33 and a maximum depth of 1.0 meters, BP is the only perennial water body within the BHW. Yet, it is important to note, BP dried completely for the first time in September, 2014 (Emma Pletz, pers. comm., September 2014). The "East Pond" (EP) is the smallest pond at 0.43 acres and shallowest, drying completely by mid-July. Ludwigia peploides ssp. montevidensis has not yet been detected within EP.

The entire 10.67 acre property is legally managed by 104 homeowners of the East Columbia Neighborhood as indicated in Exhibit E of the Common Open Space Maintenance Agreement (Appendix G). Identified residents are legally responsible for the restoration and maintenance of the BHW in connection with the Common Open Space Agreement. In the sale of a home, it is the selling 
individual's responsibility to pass the information to the buying homeowner. In reality, many

homeowners of the East Columbia Neighborhood do not possess a copy of Exhibit E and are unaware of their legal obligation to the wetland property. A governing authority that contributes to decisions regarding activity within the wetland property is the East Columbia Neighborhood Association (ECNA) board composed entirely of East Columbia Neighborhood residents.

\section{F. Project Establishment \& History}

Due to the close proximity to residents' property, adjacent landowners have periodically monitored the BHW since their establishment (Emma Pletz, pers. comm. Jun 20, 2011). Three years after an aquatic weed was first noticed in the largest of the four ponds and hand pulling was deemed ineffective, an ECNA member contacted numerous authorities to receive proper identification of the plant. On November 5, 2009 samples were collected by Brenda Grewell of the United States Department of Agriculture (USDA) and the aquatic plant was identified as Ludwigia peploides ssp. montevidensis.

Upon identification of the invasive plant, an initial planning meeting was scheduled on February 10, 2010 that included representatives of the ECNA, City of Portland's Early Detection and Rapid Response Program, Portland State University Center for Lakes and Reservoirs at Portland State University, City of Portland's Bureau of Environmental Services (BES), NPNS and MCDD. The evaluation by scientists and BES staff determined removal should be attempted and various control methods be tested. The ECNA created the Blue Heron Wetland sub-committee to manage the restoration of the wetlands and eradication of L. peploides ssp. montevidensis.

In the summer of 2010, the ECNA organized a mechanical removal of Ludwigia peploides ssp. montevidensis with assistance of MCDD. Large machinery in the form of a Spyder Hoe, an amphibious excavator removed approximately $110 \mathrm{yd}^{3}$ of material from the perimeter of BP. The material was 
placed on-site with tarps above and below the biomass to prevent regrowth until off-site disposal could be carried out.

In 2011, the ECNA applied for and received funding from EMSWCD in the form of a Partners in Conservation Grant, Metro's Nature in Neighborhoods Grant, Intel and NPNS to fund the BHWRP. A contractual agreement was then created with the ECNA and Portland State University (PSU), to provide project leadership through a graduate student within the Department of Environmental Management. In July 2011, Alex Staunch, a Masters of Environmental Management student at PSU, was hired as Project Coordinator. Alex's involvement with the BHWRP partially fulfills the requirements for the Masters of Environmental Management Degree at PSU. Funds of the BHWRP are administered by NPNS. Grants awarded in 2011 for direct management expired on December 31, 2014. The BHWRP will continue to be funded until September of 2016 by a new cycle of the Nature in Neighborhoods Grant from Metro which was awarded in September of 2014.

\section{CONTROL METHODS}

The "Control Methods" section highlights the steps taken for the direct eradication of $L$. peploides ssp. montevidensis within the BHW. Establishment of the monitoring plots and scientific design are highlighted as well. Details of direct weed control, volunteer efforts and treatment of removed material are described. Methods and results of monitoring are highlighted in the following section, "IV. Monitoring Methods and Results". For clarification purposes, the timeline portrays both control efforts and scientific monitoring for the herbicide efficacy pilot test and during widespread management of L. peploides ssp. montevidensis within the wetlands (Figure 3). 


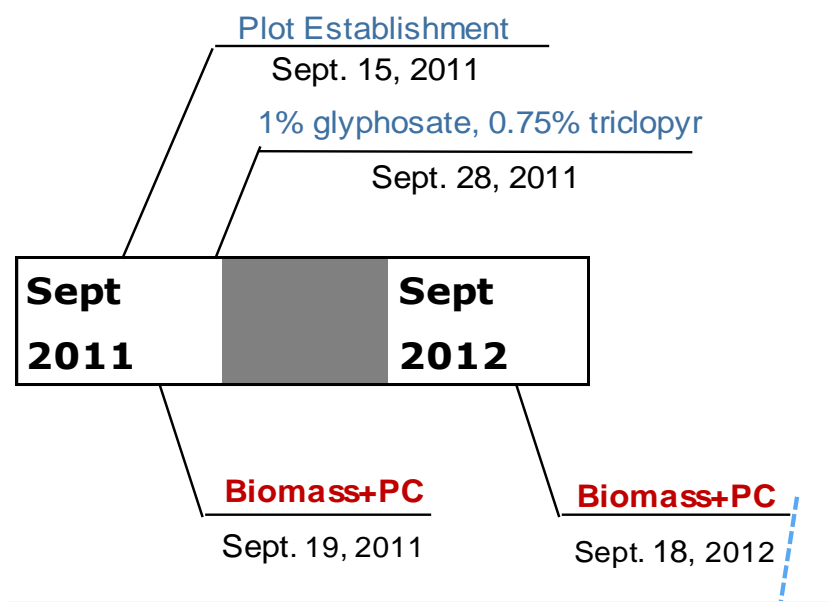

Control and Monitoring (Sept. 3, 2012 to Sept. 26, 2014)
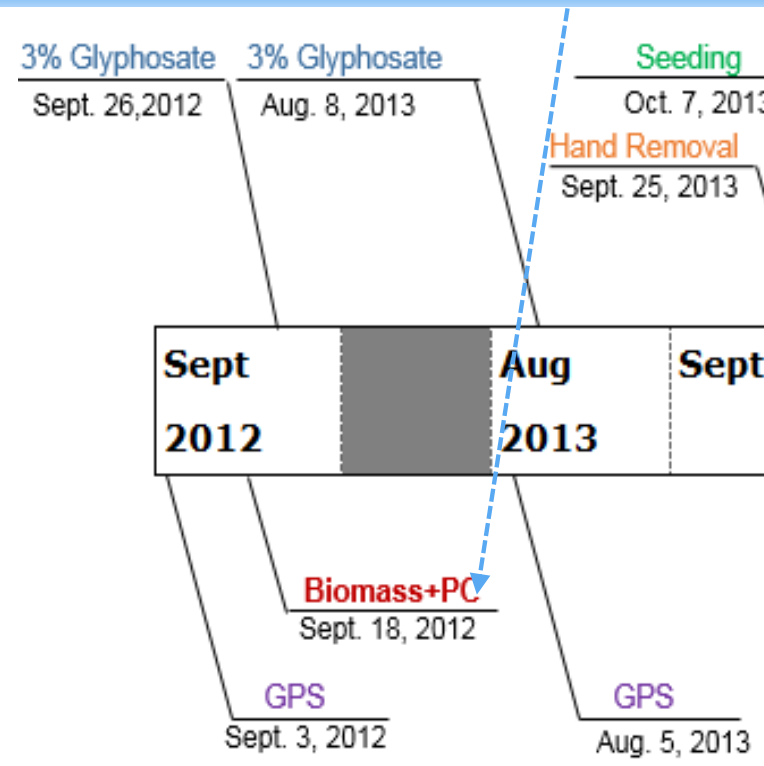

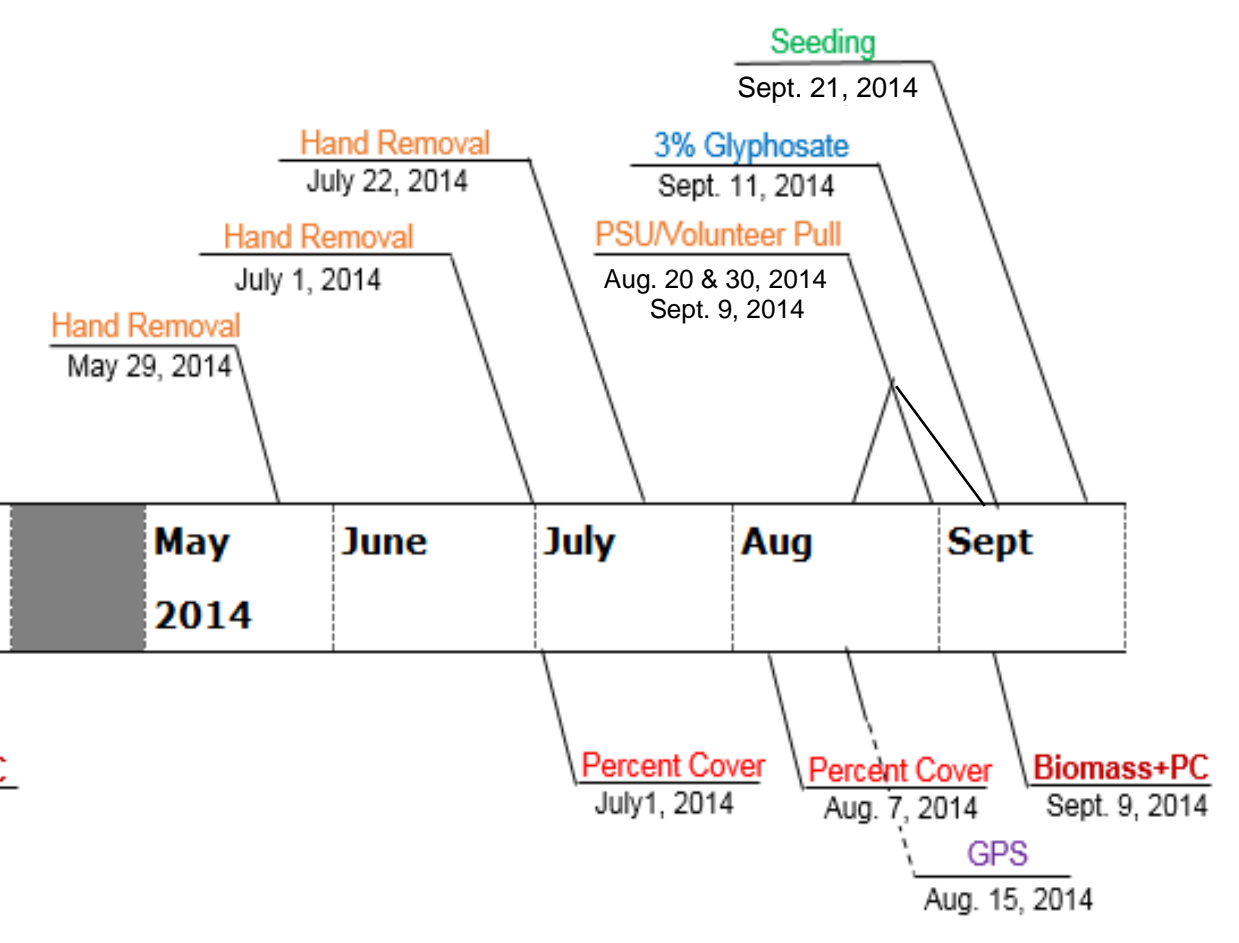

Figure 3. Timeline of the BHWRP associated with monitoring and control efforts. Final data collection for the pilot study (Sept. 18, 2012) also acted as baseline measurements for the monitoring of widespread control efforts within the wetlands. Monitoring events are below and control actions are above the timelines. "Biomass+PC" represent dates in which both biomass and percent cover data were recorded. 


\section{A. Herbicide Efficacy Pilot Test 2011}

Due to the limited local knowledge related to eradicating Ludwigia spp. and the unknown response of the residents in relation to the use of herbicide in the BHW, a small scale pilot test was established in the DP during September of 2011 (Figure 3). The pilot test compared two different herbicide treatments at low doses. Upon alerting the neighborhood of application, concerned homeowners were invited to be properly informed and educated regarding the use of herbicides in the wetlands and encouraged to engage in further conversation prior to future application. The pilot study provided evidence of how specific herbicide mixes control L. peploides ssp. montevidensis within the BHW and assisted in the creation of control methods for the coming years. The pilot study consisted of four major phases, visible in Figure 3.:

1) Plot establishment - September 15, 2011

2) Baseline data collection - September 19, 2011

3) Chemical application (1\% glyphosate, $0.75 \%$ triclopyr) - September 28,2011

4) Data collection - September 18, 2012

Nine $8 \mathrm{~m} \times 8 \mathrm{~m}$ test plots were established within the DP prior to application. In attempts to control for various environmental variables, plots were placed in areas of similar water depth and initial cover of L. peploides ssp. montevidensis. All areas contained dense stands of L. peploides ssp. montevidensis and soils had remained saturated throughout the growing season as of September 2011. Treatments within the plots included triclopyr $(n=3)$, glyphosate $(n=3)$ and a control group $(n=3)$. The herbicide products were used at concentrations of $1.0 \%$ triclopyr in the form of Element $3 \mathrm{~A} \circledR$ (Anonymous, 2009a) and 0.75\% glyphosate in the form of Aquaneat ${ }^{\circledR}$ (Anonymous, 2007) for the treatment of Ludwigia spp. On September 28, 2011 herbicides were applied with $0.5 \%$ of the surfactant Competitor®. Chemical application within the BHW was carried out with backpack sprayers fitted with 
precision applicators to reduce drift. Plots were monitored in September of 2012 to assess efficacy of herbicide applications.

\section{B. Herbicide Application - September 2012 to September 2014}

During large-scale eradication efforts in 2012, 2013 and 2014, herbicides were applied at a rate of 3\% glyphosate in the form of Aquamaster ${ }^{\circledR}$ or Rodeo ${ }^{\circledR}$. Glyphosate was increased to $3 \%$ based on the unsatisfactory results of the pilot study and emerging best management practices being used by local land managers. The surfactant Competitor ${ }^{\circledR}$ was added at a concentration of $2 \%$ to increase herbicide efficacy and blue dye was used for visibility. In 2012 and 2013, five to six member contract crews surveyed and applied herbicide to 1.85 acres each year. Application occurred on all individuals of $L$. peploides ssp. montevidensis except for those within the control plots, previously established in 2011. In order to reduce the risk of exposure to non-target species, application within the open water areas of the BP were minimized. The few individuals present within these areas were removed by hand prior to application. In 2014, the 3\% glyphosate application occurred to treat the control plots of untreated $L$. peploides ssp. montevidensis that remained. Small amounts of spot application occurred outside of the control plots to address areas that were experiencing intense regrowth. Roughly 1.0 acre in total was surveyed and treated during the $3 \%$ glyphosate application of 2014. Herbicide application was carried out in accordance with Federal and State laws and rates adhered to recommended rates of pints/acre/year ( $\mathrm{pt} \mathrm{ac} \mathrm{ar}^{-1}$ ) of active ingredient (Anonymous, 2009b).

The first chemical application of 3\% glyphosate was administered on September 26, 2012. Application of herbicide in early fall was selected to coincide with the allocation of carbohydrates and materials to the root system for winter dormancy, increasing the likelihood of a systematic kill. The dates of application were adjusted in 2013 in response to emerging knowledge and best management practices used by local land managers. In 2013, it was better understood that herbicide efficacy is 
increased for Ludwigia spp. when application occurs before or during flowering (Brenda Grewell, pers. comm. cited from City of Eugene, 2013). Due to the ephemeral nature of the BHW, a majority of the population of L. peploides ssp. montevidensis flowered in late-July to early-August in response to soil drying. To apply herbicides during the flowering stage, date of application was adjusted to August 8 , 2013. The chemical application of 2013 represented the last widespread application of herbicide in the BHW. On September 11, 2014 monitoring plots that did not previously receive treatment were chemically applied by a representative of the City of Portland's BES with 3\% glyphosate. During this time, areas experiencing rapid regrowth were spot sprayed to prevent reestablishment.

\section{Hand Removal - September 2013 to September 2014}

To reduce the use of herbicides within the BHW, hand removal was used as the primary method of control after the August 8, 2013 chemical application. Hired contract crews were used the most frequently and comprised 173 of the total 233 hours of hand removal (Picture 3) (Table 1). Although the entire extent of the wetlands was surveyed and hand-pulled, high removal efforts were

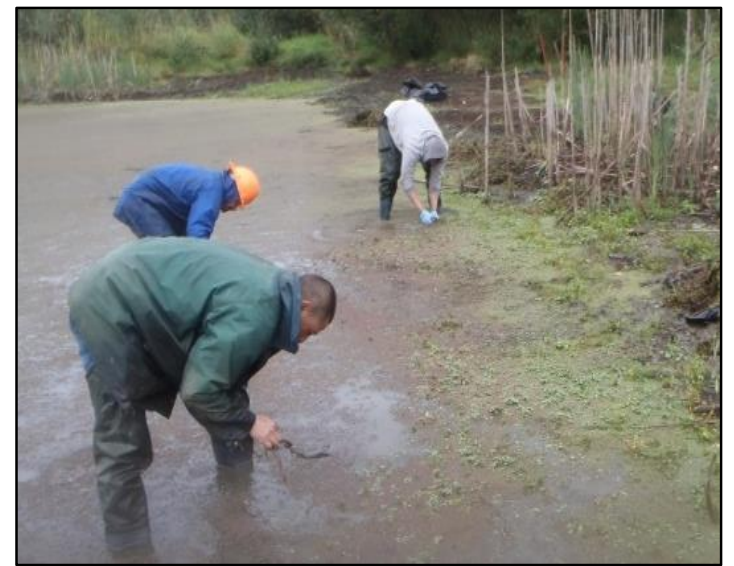

Pic 3. Hand pulling along the banks of the 'Big Pond. concentrated on the outskirts of the infestation in order to reduce the overall range of $L$. peploides ssp. montevidensis. The first removal event occurred seven weeks after chemical application to identify individuals that were not effectively treated. At this time, heavy rains from early September had filled the wetlands to capacity stimulating rapid growth of L. peploides ssp. montevidensis to the water surface. The saturated clay and silt soils of the BHW permitted easy removal of root systems reducing the threat of fragmentation by pulling. 
Table 1. Hand removal events within the BHW by date.

\begin{tabular}{|c|c|c|c|c|c|}
\hline Date & Resource & No. of Individuals & Hours Worked & Total Hours & Acres \\
\hline September 25, 2013 & Contractor & 7 & 7 & 49 & 2.4 \\
\hline May 29, 2014 & Contractor & 6 & 5 & 30 & 2.4 \\
\hline July 1, 2014 & Contractor & 7 & 8 & 56 & 1.8 \\
\hline July 22, 2014 & Contractor & 6 & 8 & $38^{*}$ & 1.5 \\
\hline August 18, 2014 & PSU Work Party & 3 & 6 & 18 & 0.3 \\
\hline August 30, 2014 & ECN Volunteers & 4 & 3 & 12 & 0.5 \\
\hline September 9, 2014 & PSU Work Party & 5 & 6 & 30 & 0.3 \\
\hline
\end{tabular}

* Members of the contract crew had to leave the hand pulling event early resulting in a reduction of expected hours.

By early May 2014 individuals of L. peploides ssp. montevidensis began to surface, making hand removal possible. Dates for hand pulling were selected based on need and the estimation of eight hour work days for contract crews. As standing water receded, seeds germinated on exposed banks requiring relatively consistent hand removal events. Because of the rapid growth rate of L. peploides ssp. montevidensis, plants quickly became large enough to spot easily and remove.

As of August, contract crews were difficult to acquire due to contractual obligations working elsewhere. The BHWRP focused on recruiting volunteers and student workers to administer manual removal. Students within the Environmental Science \& Management Department at PSU were contacted to execute hand removal within the BHW (Picture 4) (Table 1). Volunteers of the East Columbia Neighborhood worked within a dry portion of the wetlands during the "Last Saturday in the Wetlands" event that occurred monthly (see section F).

Observationally, the work carried out by students and volunteers was more thorough than that of the contractors, but moved at a slower pace. The removed L. peploides ssp. montevidensis was placed on a terrestrial portion of the site and covered with a tarp to allow decomposition.

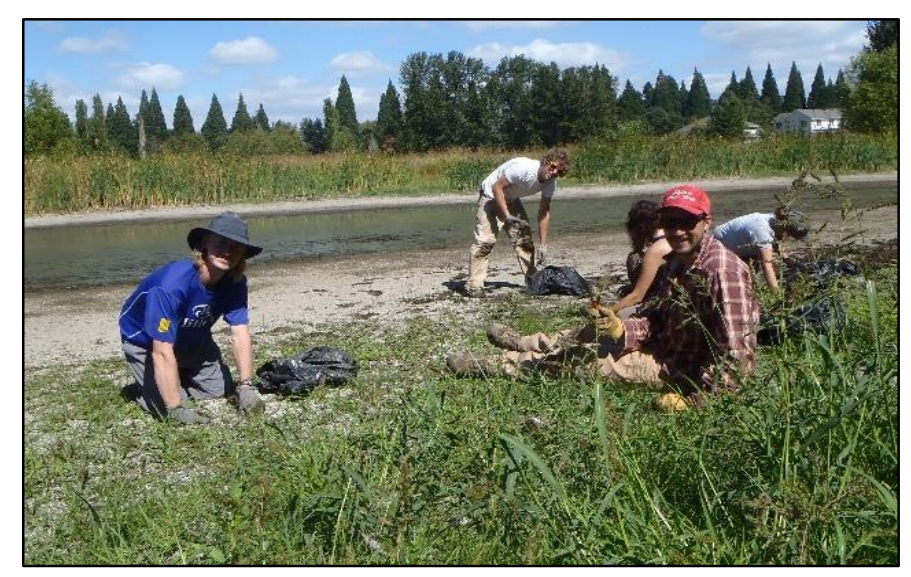

Pic 4. PSU students carrying out hand removal within the BHW. 


\section{Seeding}

To minimize regrowth of $L$. peploides ssp. montevidensis and other invasive plant species in the newly exposed areas, the wetlands were seeded with 28 pounds of native wetland forbs and graminoids on October 7, 2013 and September 21, 2014. A variety of species were selected in hopes that native plant diversity would increase and a majority of the micro habitats would be colonized by native plants. The seed mix contained species that provide habitat and food resources to waterfowl and mammalian species. Seeds were provided from a local distributor and contained plants native to the Pacific Northwest (Table 2).

Seeds were applied to all areas previously or currently occupied by L. peploides ssp. montevidensis with a chest seeder, totaling 1.85 acres. Test plots also received application of seed mix. The 2013 seeding occurred after heavy rains resulted in the wetlands being at capacity. The date of seeding was moved earlier during the 2014 season to allow seeds to be present on exposed soils prior to rainfall which permitted stratification.

Table 2. Composition of 28 pound seed mix applied to BHW on October 7, 2013 and September 21, 2014 by chest seeder. Percentages represent seed ratio by weight.

\begin{tabular}{|c|l|l|}
\hline$\%$ & Latin Name & Common Name \\
\hline 35 & Beckmannia syzigachne & American sloughgrass \\
\hline 20 & Glyceria occidentalis & Western mannagrass \\
\hline 15 & Eleocharis palustris & Common spike-rush \\
\hline 15 & Leersia oryzoides & Rice cutgrass \\
\hline 10 & Sparganium eurycarpum & Broadfruit bur-reed \\
\hline 1 & Carex obnupta & Slough sedge \\
\hline 1 & Schoenoplectus tabernaemontani & Softstem bulrush \\
\hline 1 & Scirpus microcarpus & Panicled bulrush \\
\hline 1 & Juncus effuses & Soft rush \\
\hline 1 & Sagittaria latifolia & Broadleaf arrowhead \\
\hline
\end{tabular}




\section{E. Disposal of Biomass}

The L. peploides ssp. montevidensis biomass from the 2010 mechanical removal by MCDD remained on site in six individual piles totaling $99 \mathrm{~m}^{2}$ in total area. The piles remained underneath black tarps, isolated from water and sunlight (Picture 5). Tarps lined the bottom of the piles to prevent possible rooting from the removed biomass. The biomass was monitored numerous times each year to detect live individuals. Piles were periodically searched to detect seed pods. No regrowth was observed within the covered piles as of winter 2012 .

Originally, funding from the 2011 grant award allocated $\$ 6,500$ towards lined dumpsters for removal of biomass from the BHW during the summer of 2011. Removing the biomass in dumpsters involved a contract crew, large machinery and transport to another location. These actions would have resulted in a large disturbance to the natural area, possible spread of $L$. peploides ssp. montevidensis during transport and a significant portion of funding would have been exhausted. Tarps were used as an alternative method to treat the removed biomass within the confines of the wetland property.

Biomass remained tarppd for two and a half years until March 20, 2013. A volunteer event removed the plastic material and plant over 200 native forbs and shrubs on the decayed plant material to

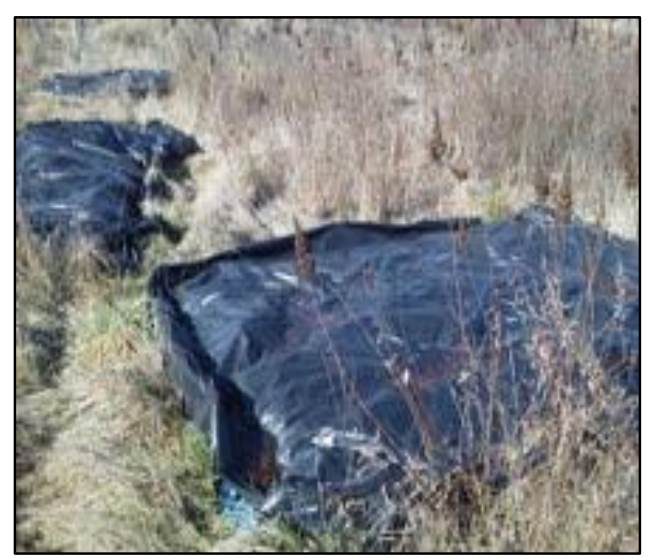

Pic 5. Ludwigia peploides ssp. montevidensis on site since 2010 mechanical removal. reduce colonization by exotic plant species (Appendix B). The alternative treatment resulted in a total budget savings of $\$ 5,400$. No L. peploides ssp. montevidensis regrowth had been observed in the newly exposed soils. The strategy of isolation and disposal will be repeated to dispose of biomass produced from hand removal events in the future. The alternative tarp method was low energy, low impact and reduced project costs. 


\section{F. Stewardship Program}

Due to the inevitable expiration of grant funding, a stewardship program was initiated to engage interest and responsibility with homeowners of the East Columbia Neighborhood. The goal of the stewardship program was to educate, train and motivate a core group of residents to carryout maintenance within the BHW while monitoring and removing L. peploides ssp. montevidensis. A selfsustaining network of residents would work together to manage the infestation into the foreseeable future and contribute to the long-term goal of complete eradication.

The stewardship program was promoted through educational material and events. A total of 19 educational articles were published in the neighborhood newsletter starting in 2011. Articles focused on the importance of natural systems, wetland ecology and invasive species identification. Educational and volunteer events occurred in 2012 and 2013 to promote interest in the BHWRP and increase likelihood of resident involvement in the proposed stewardship program.

In May of 2014, the stewardship program was established. At the program's center were monthly volunteer events entitled "Last Saturday in the Wetlands". Education and hands-on training was provided to those in attendance on every last Saturday of the month $(5 / 31,6 / 28,7 / 26,8 / 30,9 / 27)$. Tours of the BHW with flora and fauna identification were provided to all participants. Restoration work such as planting, vegetation surveys, invasive plant removal and beaver caging were carried out by residents throughout the summer of 2014. Most importantly, a core group of five residents were successfully trained to survey, identify and remove L. peploides ssp. montevidensis.

Initially, the monthly volunteer events showed a high attendance with individuals from other neighborhoods or institutions attending. PSU students comprised 12 of the 22 attendees during the May 31, 2014 event, with only one student appearing at events in the following months. As the summer progressed, participation in the "Last Saturday in the Wetlands" decreased and consisted of only East 
Columbia Residents (Figure 4). The trend in attendance was expected and helped harbor collaboration between residents. Five residents attended multiple events, while two residents attended all events. The stewardship program produced a small, tightly knit, educated group of individuals that are not only legally obligated to the property, but invested in the removal of $L$. peploides ssp. montevidensis from the BHW.

Figure 4. Attendance of "Last Saturday in the Wetlands" events during 2014. Attendees were comprised of East Columbia residents and PSU students.

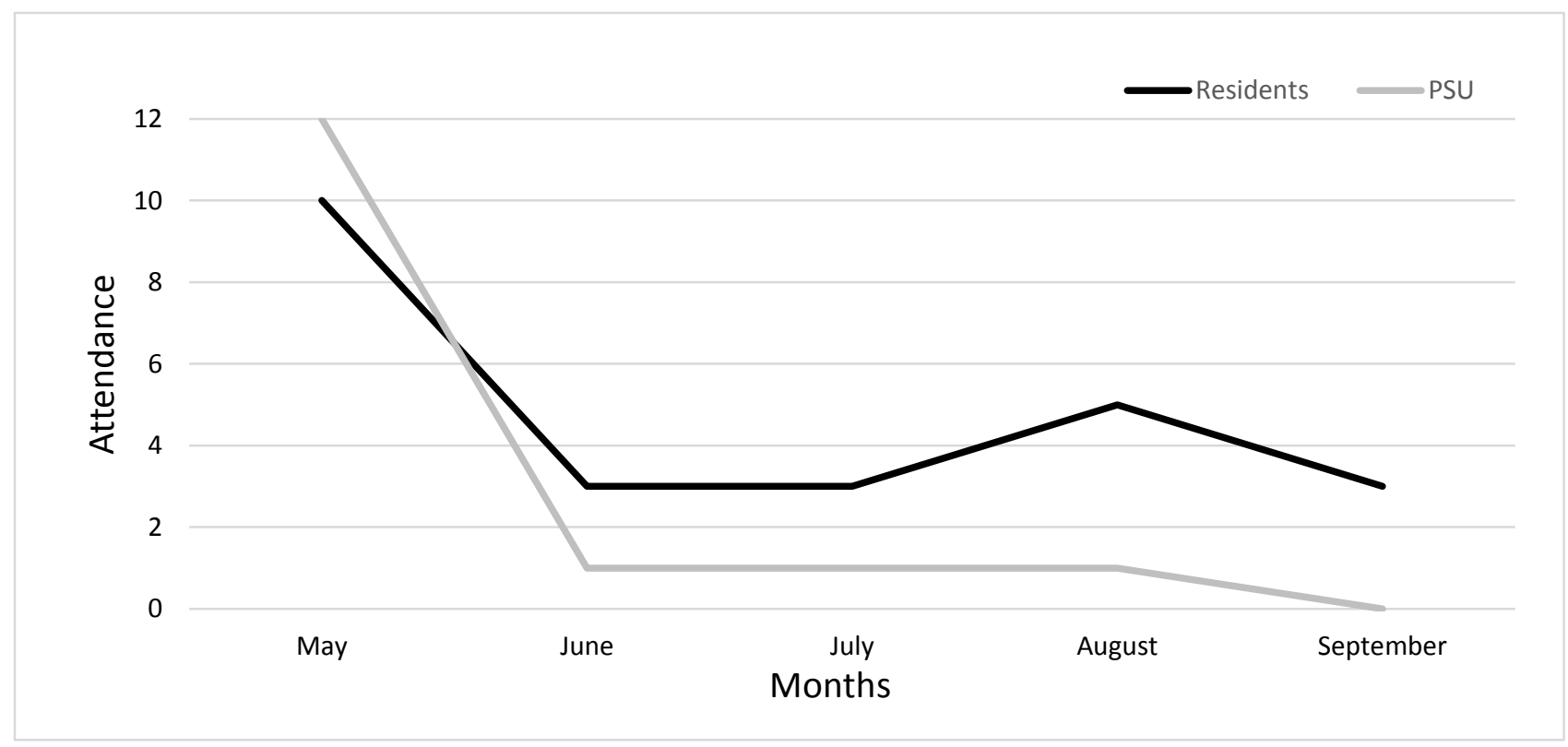

\section{MONITORING METHODS \& RESULTS}

The "Monitoring Methods \& Results" section highlights the methods and findings regarding data collection to assess the efficacy of control efforts in the BHW. The initial pilot study and progress of overall eradication efforts are described in the section below. Summary of volunteer work and hours provided are present. Interpretation of results from pilot study and wetland monitoring are presented within "VI. Lessons Learned". 


\section{A. Herbicide Efficacy Pilot Test 2011}

\section{Methods}

Within the nine monitoring plots of DP, visual percent cover estimates and biomass averages were measured within the triclopyr $(n=3)$, glyphosate $(n=3)$ and control $(n=3)$ treatments. Samples were collected at least 1 meter within the plots on all sides to negate edge effects resulting from plant growth outside of plots that were not sprayed. Biomass averages for each plot were generated from four sub-samples within the sampling area. The four sub-samples were taken in intervals along a diagonal to account for two-dimensional variation of environmental

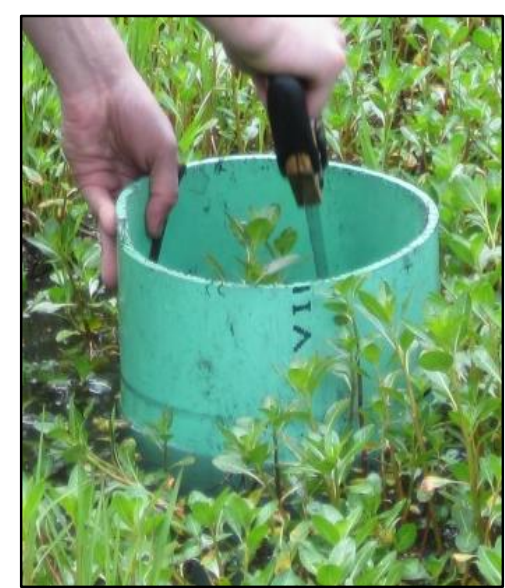

Pic 6. Primitive, yet effective corer used to collect biomass of target weed. variables within the plot. Biomass samples were collected with a 0.254 meter (10 inches) diameter PVC pipe $\left(0.0507 \mathrm{~m}^{2}\right)$. The PVC pipe was lowered within the water column and L. peploides ssp.

montevidensis material, both above ground and below ground biomass was gathered (Picture 6). Material was immediately transported to a lab where the samples were separated, cleaned and dried to obtain dry mass (DM). Drying occurred within a drying oven at $85^{\circ} \mathrm{C}$, until constant dry weight was observed. Estimates of percent cover were assessed by standing at each corner of the monitoring plot. Picture points of plots were taken upon plot establishment and at intervals throughout the growing season of 2012 to assess regrowth (Appendix C). Significant differences of biomass and percent cover between treatments and years were assessed by Bonferroni corrected t-tests. Statistical analyses was carried out using R statistical package $3.0 .2^{\odot}$ software. The threshold for statistical significance between groups was considered to be $P=0.05$. 


\section{Results}

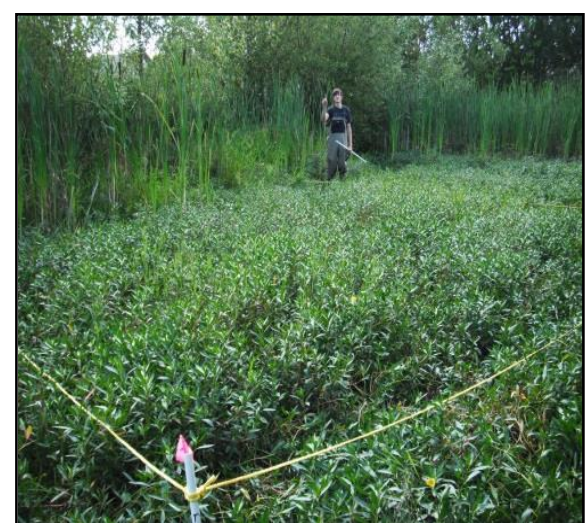

A) September 19, 2011 (Pre-Spray)

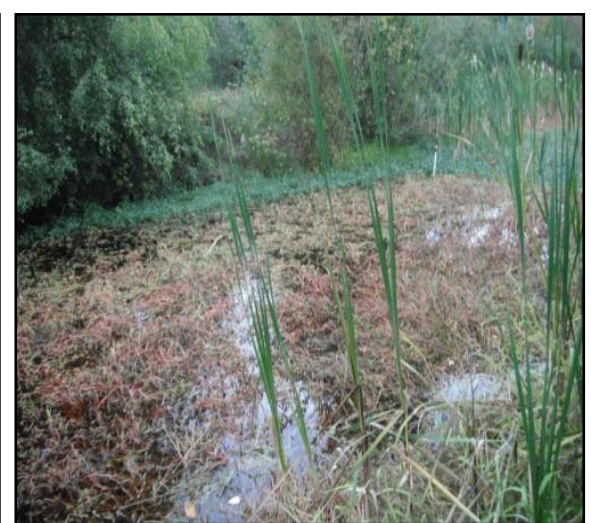

B) October 10, 2011

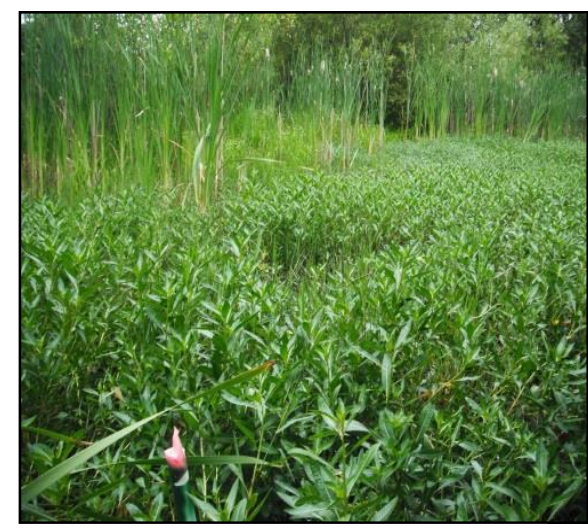

C) August 8, 2012

Figure 5. Picture points from plot T1. Applied with 1.0\% Triclopyr in September of 2011. Initial results appeared promising with a rapid yellowing and curling of leaves (B). Regrowth appeared to return to pre-spray levels (A) less than one year after application(C). Photograph B was taken at a different angle.

Although one month after application (October 10, 2011), L. peploides ssp. montevidensis appeared to be negatively affected by $1 \%$ triclopyr and $0.75 \%$ glyphosate, all plots returned to similar appearances less than one year after application on September 18, 2012 (Figure 5) (Appendix C). Percent cover of $L$. peploides ssp. montevidensis returned to almost identical pre-spray values (Figure 6B). Biomass averages yielded mixed results. Control and glyphosate groups both experienced increases in total average biomass of $12 \%$, while the triclopyr plots decreased by $47 \%$ (Figure 6A). The decrease within the triclopyr group yielded statistically significant differences between pre and post-application averages. This is interesting since percent cover values were almost identical during both periods of biomass sampling. The difference could be attributed to errors made by the observer during data collection, small sample size, annual variation in precipitation or other environmental variables such a water depth or interspecific competition with other plants species. Based on percent cover readings and observations in the field, it appears that $1 \%$ triclopyr and $0.75 \%$ glyphosate do not adequately control $L$. peploides ssp. montevidensis to meet short-term or long-term goals of the BHWRP. Concentrations of herbicide for the control of water primrose should be increased in order to provide a systematic kill of 
the plant. Pre and post treatment sampling yielded biomass values of L. peploides ssp. montevidensis within the range of populations found in California (Rejmankova, 1992).

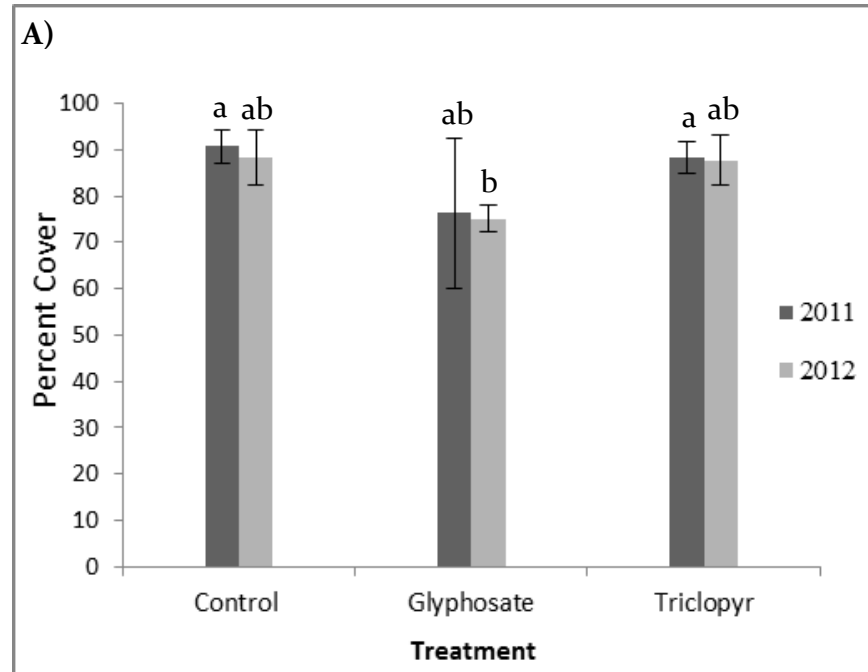

B)

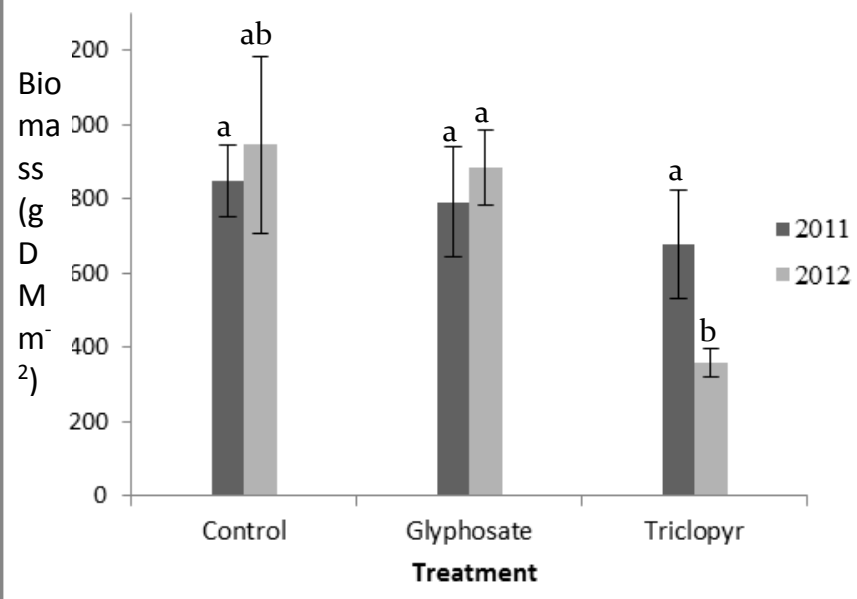

Figure 6. Percent cover (A) and total average biomass (B) of Ludwigia peploides ssp. montevidensis in DP, one year after application of $1 \%$ triclopyr and $0.75 \%$ glyphosate. Different letters indicate a significant difference.

\section{B. Plot Analyses 2012 to 2014}

The results of the 2011 pilot study and recommendations from other land managers led to the use of an increased concentration of the herbicide glyphosate for control of the L. peploides ssp. montevidensis infestation. The 3\% glyphosate application was applied to all L. peploides ssp. montevidensis individuals in the BHW, except for the open water habitat of the BP and within control plots. The monitoring plots were used to assess only the effect of $3 \%$ glyphosate on L. peploides ssp. montevidensis. Therefore, hand removal did not occur within test plots. Effectiveness of hand removal coupled with 3\% glyphosate application was assessed through range \& density mapping.

\section{Methods}

To increase monitoring effectiveness and assess variability within the wetlands, six additional monitoring plots were constructed in the WP to quantify the effect of $3 \%$ glyphosate application (Figure 2). Control $(n=3)$ and treatment plots $(n=3)$ were placed along the length of the WP at least eight 
meters from one another. Due to limited space within the pond, water depth and initial L. peploides ssp. montevidensis cover varied between plots, resulting in high standard error values of each group (Figure 7; Figure 8). Methods for plot establishment and data collection were identical to those used in the pilot test. The original control plots in the DP were preserved to assess the effectiveness of the $3 \%$ glyphosate application. From the pilot test, the triclopyr and glyphosate groups were treated with the increased glyphosate concentration and statistically analyzed as one treatment group $(n=6)$ since the application group did not significantly differ in percent cover $(P=0.99726)$ or average biomass $(P=0.643867)$ from the control group $(n=3)$ (Figure 6). Baseline data collection occurred on September 18, 2012 prior to glyphosate application on September 26, 2012.

Annual change in biomass and percent cover of L. peploides ssp. montevidensis were assessed on September 20, 2013 and September 9, 2014. Regrowth throughout the 2014 growing season was assessed by percent cover readings on July 1, August 7, and September 9. Significant differences across treatments were tested using the Kruskal-Wallis one way analysis of variance. If a significant difference was detected through the ANOVA, tukey post hoc tests were used to investigate statistical significance between groups. Statistical analyses were conducted with the assistance of R i386 3.0.2 ${ }^{\odot}$ statistical software.

\section{Results}

The Kruskal-Wallis test detected significant differences across treatments and time for biomass within DP $(P<0.0001)$, biomass within WP $(P=0.0002)$, annual percent cover within DP $(P=0.001)$ and monthly percent cover within DP $(P=0.0004)$. Non-significant differences were detected within WP for annual percent cover $(P=0.2089)$ and monthly percent cover $(P=0.1505)$. After the chemical applications of September 26, 2012 and August 8, 2013, biomass values within treatment plots decreased by $95.5 \%(P<0.0001)$ and $96.6 \%(P=0.0128)$ within DP and WP respectively by September 
20, 2013 (Figure 7). In September 2014, more than one year after the last chemical application, reestablishment was observed within the treatment plots (Figure 7). Biomass within the treatment plots increased by $1,151.8 \%$ in DP and $1,982.2 \%$ in WP after one year without control. The treatment plots of 2014 in DP were no longer significantly different than pre-application levels $(P=0.1135)$, yet were significantly different from the control plots of 2012 and $2014(P=0.0043 ; P=0.0101)$. In WP, the 2014 treatment did not significantly differ from 2012 and 2013 treatment plots $(P=0.7759 ; P=0.3567)$ (Figure 7). The control group demonstrated an initial decline in biomass within the DP from 2012 to 2013, exhibiting a rebound in 2014. Biomass within the control group of WP demonstrated a steady increase from 2012 to 2014.

Annual percent cover of L. peploides ssp. montevidensis showed similar trends in response to $3 \%$ glyphosate as the biomass samples (Figure 8). With an 86\% reduction in percent cover from 2012 to 2013 for the treatment group in DP, a near significant $p$-value was obtained $(P=0.0574)$. Yet the 2013 treatment group was significantly different from the 2013 control group $(P=0.0146)$. Both ponds showed rapid reestablishment of $L$. peploides ssp. montevidensis canopy in 2014 within the application plots. The control groups within both ponds demonstrated increased total percent cover values annually, which provided support that canopy establishment of L. peploides ssp. montevidensis was still occurring within the BHW. In WP, percent cover of treatment plots in 2014 was greater than both pre-treatment groups of 2012 (Figure 8). 


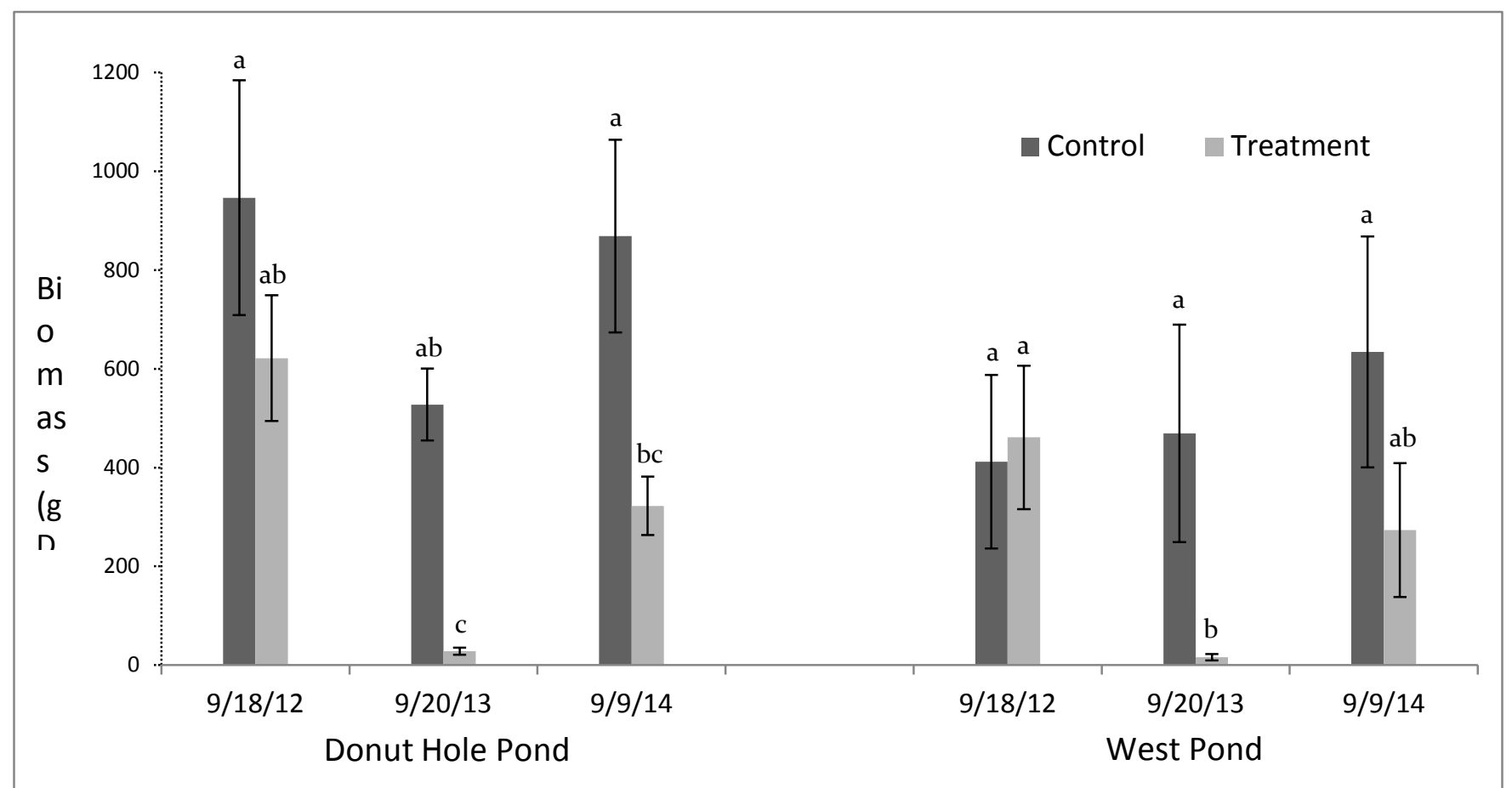

Figure 7. Annual biomass of $L$. peploides ssp. montevidensis within treatment and control plots in response to $3 \%$ glyphosate application. Different letters indicate statistical significance. Ponds were statistically analyzed separately.

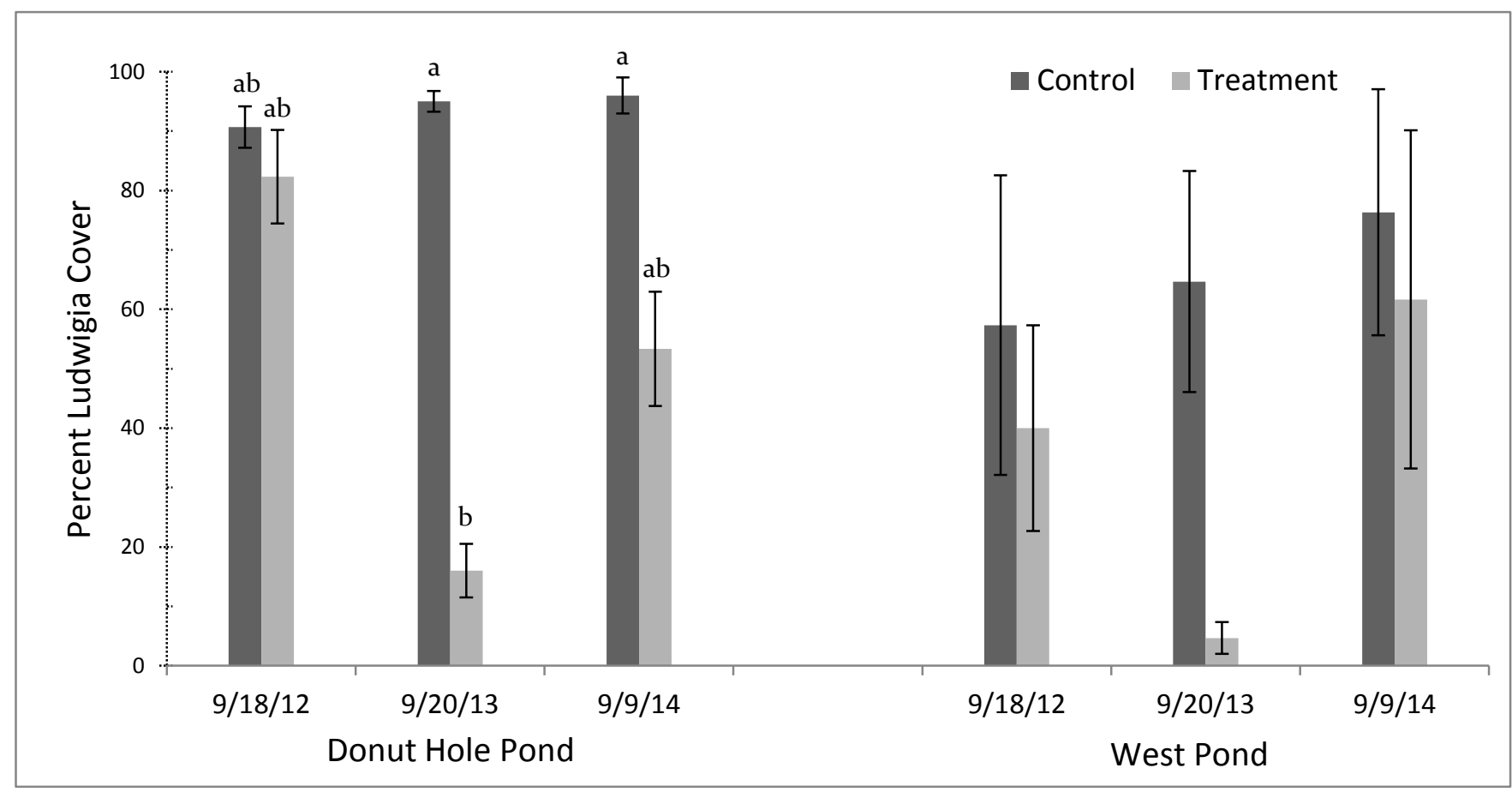

Figure 8. Annual percent cover of L. peploides ssp. montevidensis within treatment and control plots in response to $3 \%$ glyphosate. Letters indicate statistical significance. Ponds were statistically analyzed separately. The Kruskal-Wallis one way ANOVA did not detect significant differences across treatments within WP. 


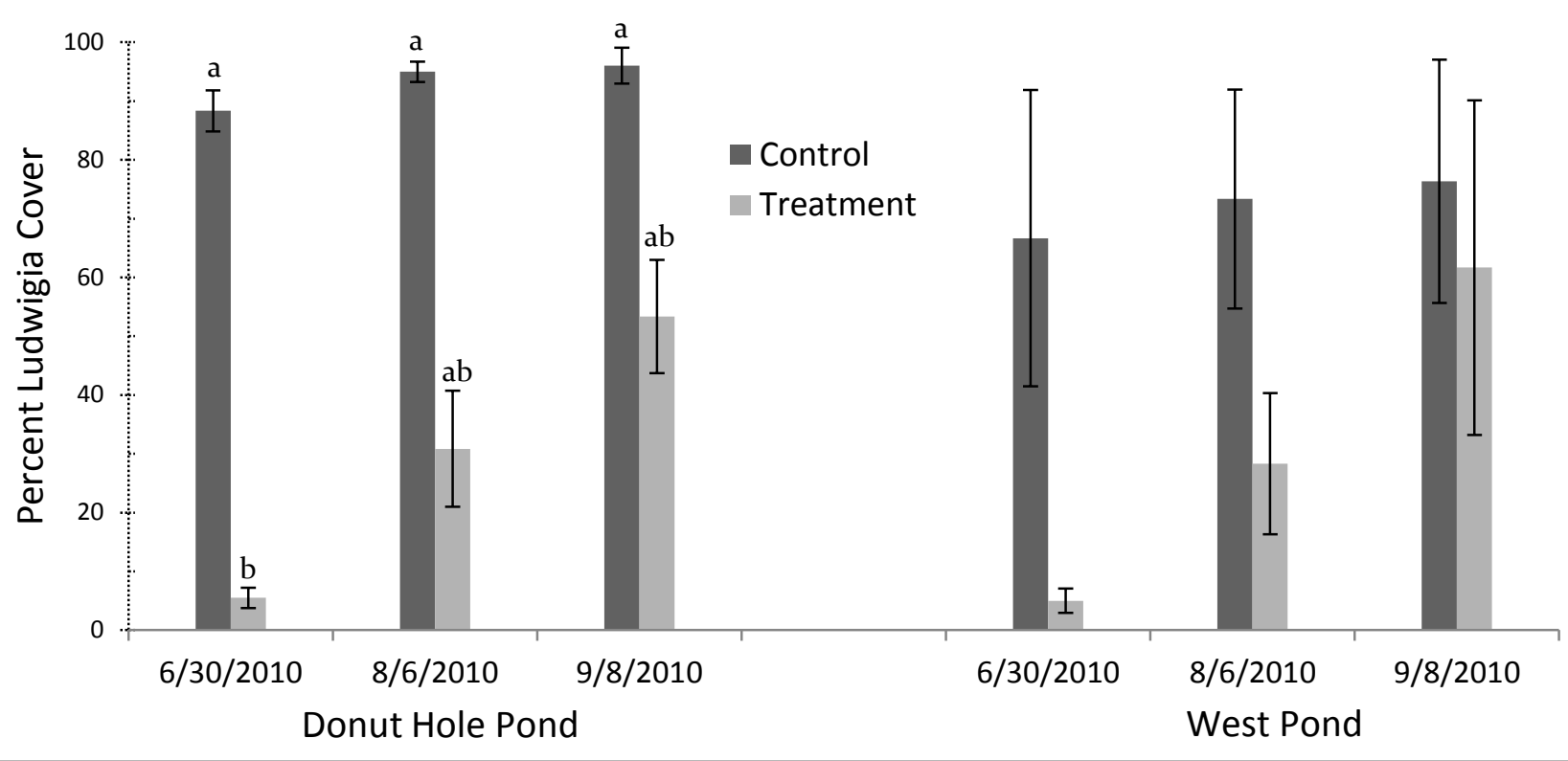

Figure 9. 2014 Monthly percent cover of $L$. peploides ssp. montevidensis within treatment and control plots. Letters indicate statistical significance. Ponds were statistically analyzed separately. The Kruskal-Wallis one way ANOVA did not detect significant differences across treatments within WP.

The monthly regrowth of L. peploides ssp. montevidensis was rapid within both ponds during 2014 (Figure 9). In July, 3\% glyphosate groups contained total percent cover values of 5.5\% and 5.0\% that increased to $53.3 \%$ and $61.7 \%$ by September 9, 2014 within DP and WP respectively. Reestablishment of total percent cover of L. peploides ssp. montevidensis within the treatment group occurred at a rate of $4.78 \%$ per week and $5.67 \%$ per week in the DP and WP respectively between the dates of data collection.

September 2014 percent cover values of the treatment group more closely resembled the control group than the biomass values (Figure 7; Figure 8). September 2014 biomass values of the treatment groups were $37.1 \%$ and $43.1 \%$ of the control group, while total percent cover values of treatment groups resembled $55.6 \%$ and $80.8 \%$ of the control groups in the DP and WP respectively. Percent cover of $L$. peploides ssp. montevidensis within the chemically applied treatment quickly recovered to levels similar to pre-spray values, while biomass values remained relatively low. 


\section{Range \& Density Mapping}

\section{Methods}

To assess the efficacy of eradication efforts at a system scale, the entirety of the L. peploides ssp. montevidensis population was mapped during each year of control. However, the hand removal by volunteers and 3\% glyphosate spot treatment that occurred after August 15, 2014 was not captured by the mapping effort. Baseline range and density measurements were taken September 3, 2012 and compared to data collected on August 5, 2013 and August 15, 2014. Dates and times were selected based on the timeline of control efforts and availability of satellites for increased accuracy of mapping efforts. The August 5, 2013 mapping took place three days before the 2013 chemical application. August 15, 2014 was selected to coincide with the life stage of L. peploides ssp. montevidensis from the 2013 data collection. "Global Navigation Satellite System Planning Online” was utilized to estimate strength of the satellite signal to ensure increased accuracy and precision during data collection (Trimble.com). Cover classes were used to assess shifts in density within areas of the wetlands. Cover classes consisted of three categories: High ( $>50 \%$ cover), Light ( $5-50 \%$ cover) and Sparse ( $<5 \%$ cover). Densities and range were assessed by a two person survey team. Each cover class was identified and traced in the field to produce a polygon. Data was collected in 2012 and 2013 using a Garmin® eTrex Vista HCx handheld GPS device. In 2014, observers used a Trimble® Juno 3B. Data for all years were collected using the World Geodetic System 84 coordinate system.

Geospatial data were analyzed and presented in ArcGIS® 10.2. Area and location of each cover class was quantified and presented in acres. The Light cover class within the 2012 mapping was extrapolated with a $3.05 \mathrm{~m}$ buffer to account for the uniform distribution of L. peploides ssp. montevidensis along the pond's perimeter. A total of 3,639 geographic points were collected in 2014 and 
differentially corrected with use of GPS Pathfinder Office ${ }^{\circledR}$ to improve accuracy. "Washington State

Reference Network - Portland Airport, OR" base station was used for differential correction.

\section{Results}

Before control efforts were administered, L. peploides ssp. montevidensis was present in 2.409 acres of the 3.510 acre wetland habitat (Figure 9). Overall density and range of L. peploides ssp. montevidensis decreased annually in response to control efforts. After chemical application in fall 2012, range of L. peploides ssp. montevidensis was reduced by a mere 0.109 acres by 2013 . Although overall range was not substantially reduced, cover classes shifted from Heavy and Light cover to Sparse cover class. Heavy cover decreased by $62.9 \%$ and Light cover was reduced by $60.7 \%$. A majority of the Heavy infestation was removed from the central portions of both DP and WP, while Heavy and Light cover classes remained along the bank areas and pond fringes (Figure 10).

With the earlier application of 3\% glyphosate on August 8, 2013 and hand removal being implemented in 2014, the overall range of L. peploides ssp. montevidensis was reduced from 2.300 ac to 0.569 ac or $76.4 \%$ from pre-application values. By 2014, the majority of cover class within the wetlands was Sparse cover allowing effective hand removal. The remaining Light and Heavy patches were targeted for hand removal by PSU and volunteer work parties in the coming weeks after mapping (Table 1). The absence of L. peploides ssp. montevidensis within the center of BP and WP is related to the easy removal of plant material from saturated soils that occurred during contractor pulls earlier in the season. Plants remained along the pond fringes during time of mapping due to difficulty in removing the entire plant in dry soils as well as germination that occurred in response to soil drying. To further assess the large-scale shifts in L. peploides ssp. montevidensis density, numerous picture points were taken periodically to provide before and after comparisons (Appendix D). 


\section{L. peploides Range \& Density within Blue Heron Wetlands}

September 3rd, 2012

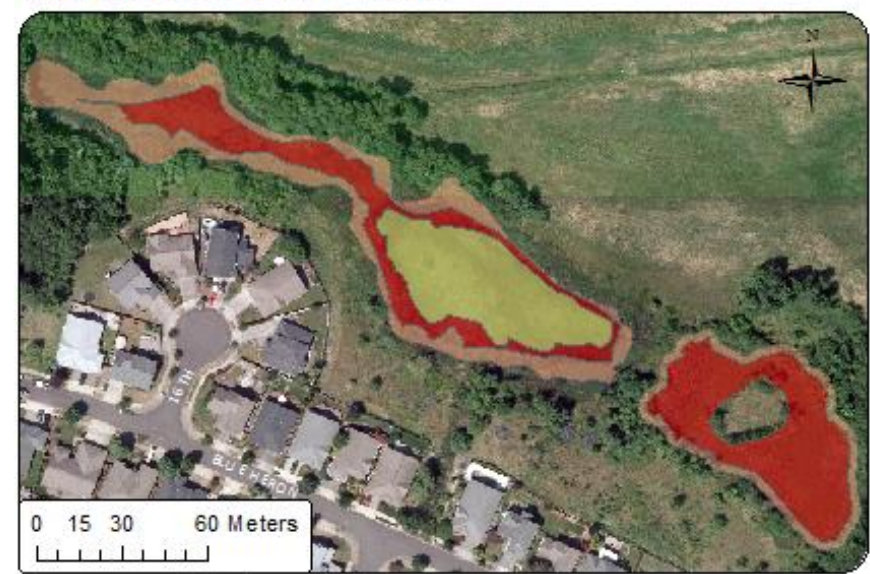

August 15th, 2014

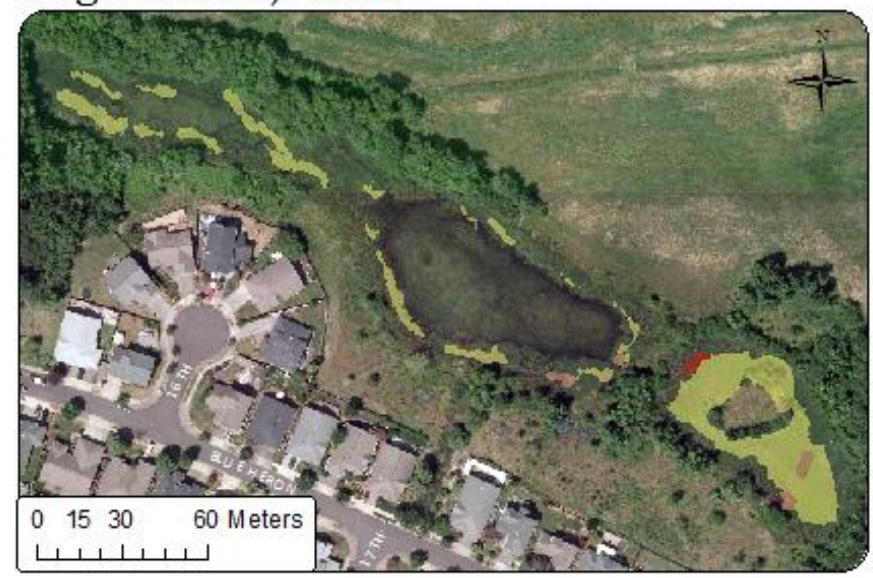

August 5th, 2013
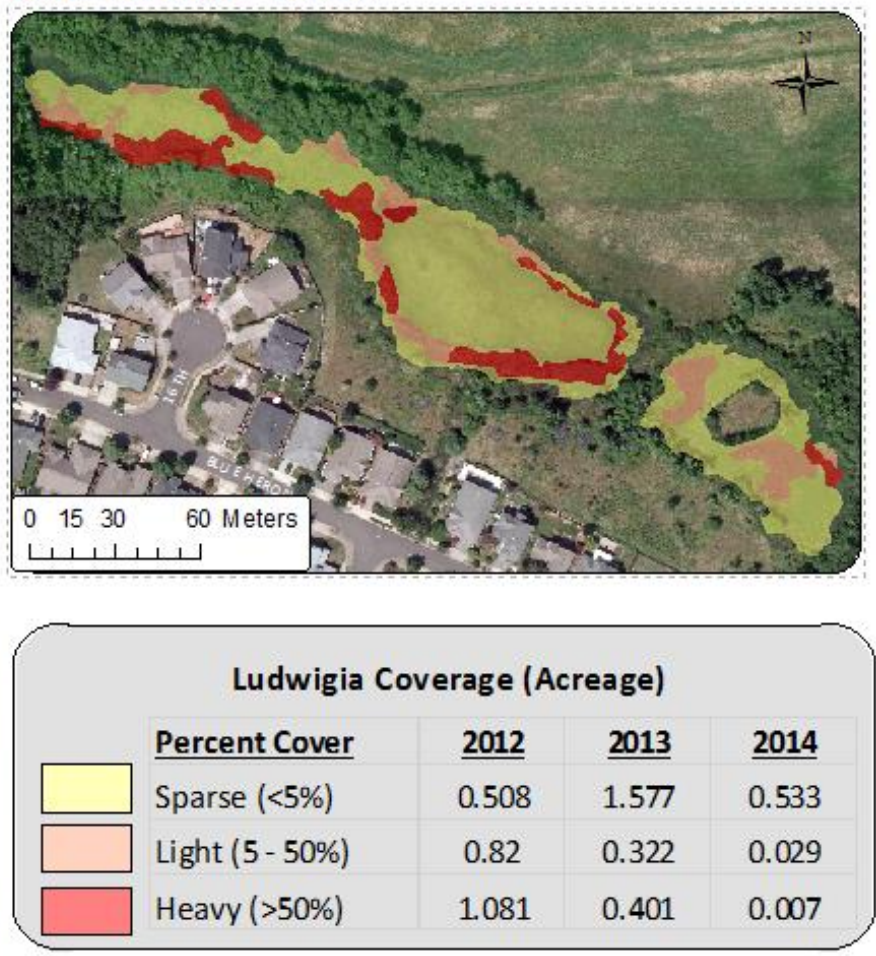

Map created for Blue Heron Wetland Restoration Project on 10/6/2014. Aerial imagery was provided by the City of Portland

Bure au of Plann ing and Susta inability.

All other data obtained from RLIS.

For additional information contact BHWetlands@ECNApdx.com.

Figure 10. Range and density of L. peploides ssp. montevidensis from 2012 to 2014 within the Blue Heron Wetlands.

\section{OUTREACH}

\section{A. East Columbia Neighborhood Residents}

To encourage participation in the stewardship program and increase involvement of the wetland property owners, residents of the East Columbia Neighborhood were the focus for outreach. Numerous methods were employed by the BHWRP to inform residents of on-going eradication efforts, provide education regarding environmental issues and recruit volunteers for restoration work. In order to do so, a multi-faceted outreach effort was coordinated to reach the target population. 
Upon project establishment, educational signs were posted at all bio-swales that entered the wetland property. Signs provided information regarding the establishment of the BHWRP and contact information for concerned residents. During the same time period, articles regarding the BHWRP were published in the neighborhood newsletter to further heighten interest among the residents. Soon a core group of residents were interested in the work being carried out by the BHWRP and stepped forward to be involved.

In order to reach a wider audience, the ECNA in conjunction with the Columbia Slough Watershed Council hosted the single largest event organized by the BHWRP, on May 20, 2012. "The Blue Heron Wetland Education Day" was conducted to provide a festival type atmosphere within the neighborhood to create as much exposure for the project as possible. A portion of NE Blue Heron Dr. was closed to vehicles to provide a venue for the event. Eight organizations and agencies were present at the event to interact with residents: BES, Center for Lakes and Reservoirs at Portland State, Columbia Slough Watershed Council, EMSWCD, Metro, MCDD, USDA and representatives of the BHWRP. The presenting groups reached 75 total attendants through games and informational workshops. The focus of the presenting groups was centered upon native flora and fauna, plant identification, impacts of invasive species and the natural history of the Columbia River floodplain (Picture 7).

Representatives of the BHWRP addressed questions or concerns regarding the eradication process and provided educational information on the use of herbicides in the BHW. Education day participants received a total of 81 native plants and informational material to take with them.

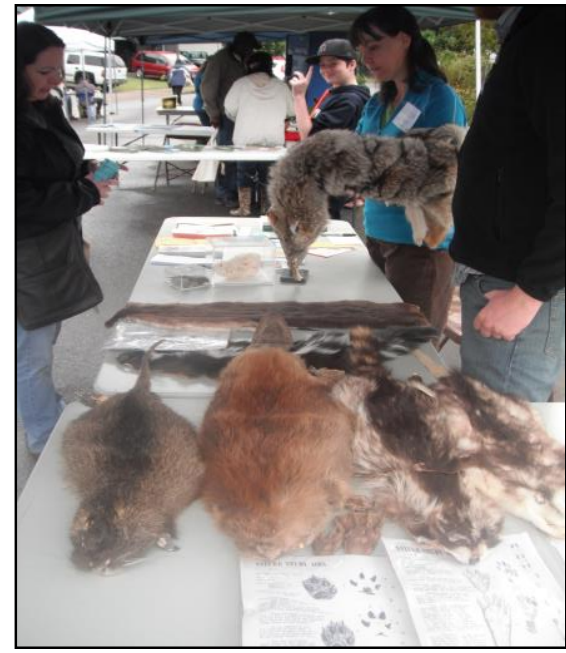

Pic 7. Metro presenting "Mammals of the Columbia Slough" exhibit. 


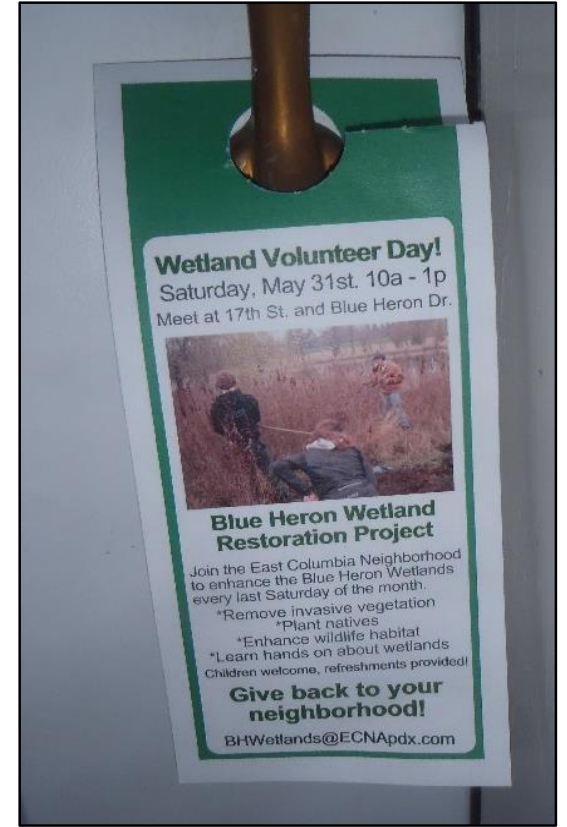

Pic 8. Door hanger used to promote volunteer events within the BHW.
The Blue Heron Wetland Education Day was used to compile contact information of all attendants to provide project and event updates. To continue reaching more landowners of the wetland property, fliers and door hangers were used to advertise upcoming volunteer events and work parties (Picture 8). Representatives of the BHWRP visited the homes of the $104 \mathrm{BHW}$ property owners to advertise work parties, announce dates of chemical application and contractor hand pull. The 1-on-1 interaction likely contributed to the high attendance of volunteer events and the tight core group of the stewardship program.

\section{B. Scientific Community}

As requested in the awarded grants, experiences and data gathered from the BHWRP were shared with the scientific community. Not only were numerous scientific entities involved in project organizing, planning and implementation, but work carried out within the BHW has been represented in posters and oral presentations at numerous scientific meetings (Appendix E). Representatives of the BHWRP have been involved with identification of Ludwigia spp. throughout the Willamette region and contributed to working groups such as the Willamette Aquatic Invasive Network in efforts to organize a joint-effort in controlling Ludwigia spp. within the Willamette River Valley and beyond.

The BHW also acted as an outdoor classroom for many Portland State students in the Environmental Science and Management Department. Students were able to gain hands-on experience conducting restoration and data collection as volunteers and as part of a class project. In fall 2011, a group of PSU students worked with the ECNA to write the initial management plan for the BHWRP as part of a classroom assignment in an upper level environmental science class, Ecology and Management 
of Biological Invasions, ESM 485/585. As stated earlier, Portland State students were employed by the BHWRP to produce maps and conduct hand removal.

\section{Volunteer Activity}

Table 3. Total volunteer hours by category contributed to the BHWRP from July 15, 2011 to December 31, 2014. Hourly rates gathered from salary or billable wages.

\begin{tabular}{|l|c|c|c|}
\hline \multicolumn{1}{|c|}{ Volunteer Category } & Total Hours & Match/Hour & Total Match \\
\hline Portland State Student & 314.75 & $\$ 22.14^{*}$ & $\$ 6,968.57$ \\
\hline East Columbia Resident & 412.25 & $\$ 22.14^{*}$ & $\$ 9,127.22$ \\
\hline Professional PSU & 97 & $\$ 42.86$ & $\$ 4,157.42$ \\
\hline Professional BES & 50 & $\$ 69.70$ & $\$ 3,485.00$ \\
\hline Professional MCDD & 20 & $\$ 36.00$ & $\$ 720.00$ \\
\hline Professional USDA & 20 & $\$ 80.00$ & $\$ 1,600.00$ \\
\hline Professional NPNS & 120 & $\$ 60.00$ & $\$ 7,200.00$ \\
\hline Professional Other & 24 & $\$ 35.00$ & $\$ 840.00$ \\
\hline & 1058 & - & $\$ 34,098.20$ \\
\hline
\end{tabular}

* Estimated worth of non-professional volunteer labor as indicated by Metro (Metro, 2014).

Not only did East Columbia Neighborhood residents and PSU students implement restoration on the ground, but numerous representatives of agencies and organizations volunteered time to planning and project implementation. A total of 1058 hours were contributed to the BHWRP in the form of volunteer labor (Table 3). The worth of donated hours was $\$ 34,098.20$ from the inception of the BHWRP to the end of initial grant funding. Professional support accounted for 331 hours. NPNS contributed primarily administrative duties, communicating with grant providers and processing funding requests. PSU assisted with project management and technical support through The Center for Lakes and Reservoirs and teaching faculty in the Department of Environmental Management. BES, MCDD and USDA provided support in implementation and project organization that was invaluable to the success of the BHWRP. 
Of the 727 hours not derived from professional contributions, PSU and East Columbia residents volunteered time on the ground, conducting many of the restoration activities. Residents participated in education, technical writing, publicity, planting, weed removal and everyday operations of the BHWRP. Portland State students were present during volunteer events and were a large part of the Blue Heron Wetland Education Day. Both residents and PSU students were responsible for planting a total of 101 forbs, 301 shrubs and 50 trees within the BHW on volunteer events of March 20, 2013, May 31, 2014, and November 15, 2014 (Appendix B) (City of Portland, 2011).

\section{Lessons Learned}

Treatments within the herbicide pilot test in September 2011, yielded insufficient control in reducing the total percent cover and biomass of L. peploides ssp. montevidensis within the BHW. Concentrations of $0.75 \%$ glyphosate and $1.0 \%$ triclopyr provided an initial appearance of senescence and death, but rapid regrowth and reestablishment of canopy occurred in the coming year (Appendix C). Although, the triclopyr treatment possessed a statistically significant reduction in biomass one year after control, small sample size $(\mathrm{n}=3)$ and variation between plots may have contributed to a Type I error, or the indication of a significant difference when there was none (Figure 6). The use of triclopyr for the management of Ludwigia spp. in eradication efforts and experiments have yielded mixed results (Champion et al. 2008; Sears et al. 2006). In management of an estuary in Sonoma County, California, Sears et al. (2006) demonstrated that relatively low concentrations of triclopyr at 1 quart per acre, acted too quickly when applied to $L$. hexapetala, killing the above ground biomass before translocation to the root system could occur. Conversely, in a greenhouse experiment, Champion et al. (2008) showed triclopyr resulted in systematic kills of all L. peploides ssp. montevidensis individuals at triclopyr concentrations from $0.25 \%$ to $5 \%$. Within the BHWRP pilot study, reduction in biomass of the triclopyr treatment could have been related to the reduction in rainfall during the water years of $2011(1.45 \mathrm{~m})$ to 
2012 (1.20 m) (USGS, 2015). Yet, decreased rainfall does not account for increased biomass for both the glyphosate and control groups.

Glyphosate applied at a concentration of $0.75 \%$ was ineffective in reducing total percent cover and average biomass one year after application (Anonymous, 2007). The reestablishment of L. peploides ssp. montevidensis canopy and increase in biomass, provide support that concentration of glyphosate applied to L. peploides ssp. montevidensis should be increased to provide an effective systematic kill (Figure 6). Initial results of the pilot study and recommendations from local managers, led to the use of $3 \%$ glyphosate within the BHW for widespread control.

The widespread 3\% glyphosate application in fall 2012 yielded effective control within the central portions of the wetlands due to the time of flowering within these regions (Figure 10). The central portions of the BHW exhibit soils that remain saturated perennially or into early September. Representatives of the Ludwigia genus demonstrate morphological and phenological shifts in response to changes in water depth and soil moisture (Dutartre et al., 2007 cited from Thouvenot et al. 2013a; Hussner, 2010). Ludwigia peploides ssp. montevidensis within perennially saturated portions of the wetlands flowered from late-August to early-October, taking advantage of the available water throughout the growing season. These areas exhibited large shifts from Heavy cover classes to Sparse cover due to timing of herbicide application in fall 2012. Dense infestations remained along the pond fringes where soil drying and flowering of L. peploides ssp. montevidensis occurred earlier in the growing season (Figure 10). Individuals along the wetland perimeter began to flower in mid-May, showing signs of senescence as early as July. The 3\% glyphosate application in August of 2013, occurred when a majority of the population along the pond fringe were in flower or just beginning to form fruiting bodies. The earlier application date of August 8, 2013, resulted in high mortality of individuals along the wetland banks and contributed to the reduction in overall range of $L$. peploides ssp. 
montevidensis that was observed in 2014. Chemical application should take place during the time of flowering for populations of $L$. peploides ssp. montevidensis. In an ephemeral wetland such as the BHW, it may be beneficial to stagger multiple applications that capture sub-populations flowering at different times of the growing season.

A main factor that contributed to the reduction in range and density of L. peploides ssp. montevidensis in 2014, was the use of hand pulling events. The four contractor hand pull events greatly reduced the Sparse cover class by removing outlying individuals and clearing L. peploides ssp. montevidensis from the central portion of $\mathrm{BP}$, where establishment of L. peploides ssp. montevidensis was limited by water depth (Figure 10). Hussner (2010) observed that L. peploides ssp. montevidensis prefers growing under shallow flooded conditions and growth is limited in waters over 0.5 meters in depth. Such growth preferences explained the Sparse density within the open water habitat of the BP. Much of the population of L. peploides ssp. montevidensis that persisted along the bank areas possessed a creeping form, while those growing in open water or saturated soils were erect throughout the season. The change in habit from erect to creeping, could result in a decreased herbicide efficacy within dried environments. In response to drying soils, L. peploides ssp. montevidensis increases overall root density and mean root depth (Hussner, 2010; Wilson, 1988). The allocation of resources to root systems, reduces the relative biomass ratio of leaves to roots, making allocation of herbicide to the root system less effective due to decreased leaf surface area (Rouse and Dittmar, 2013; Knoche and Bukovac, 1993). Early season hand removal reduced the magnitude of fructification and minimized potential of rapid biomass increase through the growing season (Lambert et al. 2010). Hand removal along the bank areas of the BHW was labor intensive, but effective. Hand trowels removed the root structures up to eight inches deep within desiccated areas. 
After the 3\% glyphosate applications, percent cover of the treatment group rebounded to values more similar to pre-application levels than biomass values (Figure 7; Figure 8). Percent cover was not significantly different between groups in the DP, while biomass measurements indicated a significant difference between control and treatment groups. The difference in ratios between percent cover of $L$. peploides ssp. montevidensis and total average biomass is related to growth habits. As previously stated, L. peploides ssp. montevidensis adopts an erect form in shallow water, while individuals are prostrate or creeping in drained, unfavorable environments (Dutartre et al. 2007, cited from Thouvenot et al. 2013). In September 2014, the monitoring plots applied with 3\% glyphosate possessed individuals of $L$. peploides ssp. montevidensis that exhibited a prostrate form of growth, while individuals within the control group were erect and formed a canopy up to two feet above the ground (Appendix C). Percent cover of L. peploides ssp. montevidensis is less sensitive to 3\% glyphosate application than overall biomass. This resulted in control and application groups with similar percent cover values while containing significantly different biomass values. The difference in growth habit between groups demonstrated the majority of growth within the control plots occurred before water receded within the ponds. The prostrate, or creeping growth habit of the application plots indicated the majority of growth occurred within a dry environment. Percent cover values throughout 2014, further support that major growth of the chemically treated L. peploides ssp. montevidensis occurred later in the growing season when water levels receded within the wetlands (Figure 9). The delayed growth of individuals in the $3 \%$ glyphosate treatment suggested that regrowth most likely occurred from seedbank recruitment or individuals that did not receive a systematic kill (Ruaux et al. 2009). In order to prevent rapid reestablishment and pre-application cover values, hand pulling should occur early in the growing season in the year following a chemical application to remove surviving individuals and emerging seedlings. 
Monitoring for L. peploides ssp. montevidensis at different times within the growing season provided different indications of herbicide efficacy. In open water habitats of the BHW, prior to application, healthy individuals of L. peploides ssp. montevidensis emerged in early-June and continued to extend above the water surface. In chemically treated areas, minimal regrowth or viability was detected until water completely receded in August or September (Figure 9; Appendix C). For many months, the only visible signs of L. peploides ssp. montevidensis were black, curled stems that provided false indication of successful chemical application. It is important for monitoring to occur in the early growing season to assess need for control, before fruits and seeds can form, but must extend to the later months when recovering plants reach the water surface and begin to increase in biomass.

Native plant species colonized areas previously occupied by L. peploides ssp. montevidensis. The most abundant colonizers were: Alisma plantago-aquatica (common water-plantain), Typha latifolia (broadleaf cattail), Glyceria occidentalis (Western mannagrass), Schoenoplectus tabernaemontani (softstem bulrush), Leersia oryzoides (rice cutgrass), Papsalum distichum and Scirpus microcarpus (panicled bulrush). Papsalum distichum competed aggressively with L. peploides ssp. montevidensis. Thick stands of $P$. distichum appeared to colonize newly exposed areas of wetland habitat at a greater rate than L. peploides ssp. montevidensis. Observationally, T. latifolia became more abundant within the BHW after active management was initiated. Papsalum distichum and T. latifolia have been found to reduce biomass and overall presence of Ludwigia spp. (Lambert, 2010; Dutartre et al. 2007, cited from Thouvenot et al. 2013). The establishment of native graminoid and forb species increase the resistance and resilience of ecosystems to colonization and spread of invasive species (D'Antonio and Chambers, 2006; Walker et al. 1999).

The short-term management goals have been successfully met. The goal of " $50 \%$ reduction in $L$. peploides ssp. montevidensis range and density during each year", was achieved with a 76.4\% reduction 
in range by August 15, 2014, less than two years after initial control took place. Densities of Light and Heavy cover have been reduced by $96.5 \%$ and $99.4 \%$ respectively. The presence of L. peploides ssp. montevidensis and the ecological impact of the invasive plant has been greatly reduced. Herbicide efficacy has been assessed and shared with local land managers, meeting the secondary short-term goal of the BHWRP.

The long-term goal of complete eradication has not yet been met. The current status of the $L$. peploides ssp. montevidensis infestation indicates that eradication is still possible. Continued monitoring and control of small, emerging populations will be critical in preventing reestablishment of L. peploides ssp. montevidensis within the BHW. The established stewardship program and upcoming hand removal efforts will further reduce the presence of L. peploides ssp. montevidensis within the BHW. The longterm stewardship program derived of East Columbia residents will continually be assessed and evaluated by ECNA representatives.

\section{FUTURE ACTIONS}

The successful reduction of L. peploides ssp. montevidensis from 2012-2014, prompted ECNA members to explore options to extend the timeline of the BHWRP. By funding the project beyond 2014, the likelihood of complete eradication would increase. On September 18, 2014, the ECNA was awarded a Nature in Neighborhoods Grant from Metro, totaling \$8,900.00. Funding from the 2014 Metro Grant will remain in effect until September 30, 2016, with discretional extensions available up to the date of June 30, 2018.

The proposed work involves communicating with contractors already familiar with the BHWRP and working with members of the established stewardship program. The project framework built in the previous three years allows the ECNA to conduct work within the BHW without the need to hire a project manager or outside source. Therefore the majority of funds can be allocated to direct control of 
L. peploides ssp. montevidensis and support to the stewardship program. The in-kind contributions of project partners ensure that professional expertise and support will be provided to ECNA members as they orchestrate upcoming work within the BHW.

Control efforts will consist exclusively of hand removal. Five removal events by contractor are proposed during the growing seasons of 2015 (3 events) and 2016 ( 2 events) (Figure 11). Of the $\$ 8,900.00$, a total of $\$ 500.00$ has been allocated to providing supplies for volunteer events and stewardship program recruitment. Timing of hand removal events differ from the proposed timeline submitted to Metro. Shifts in dates are recommended to increase efficiency of removals based on 2014 experiences and to better utilize a full eight hour day for a six man contract crew.

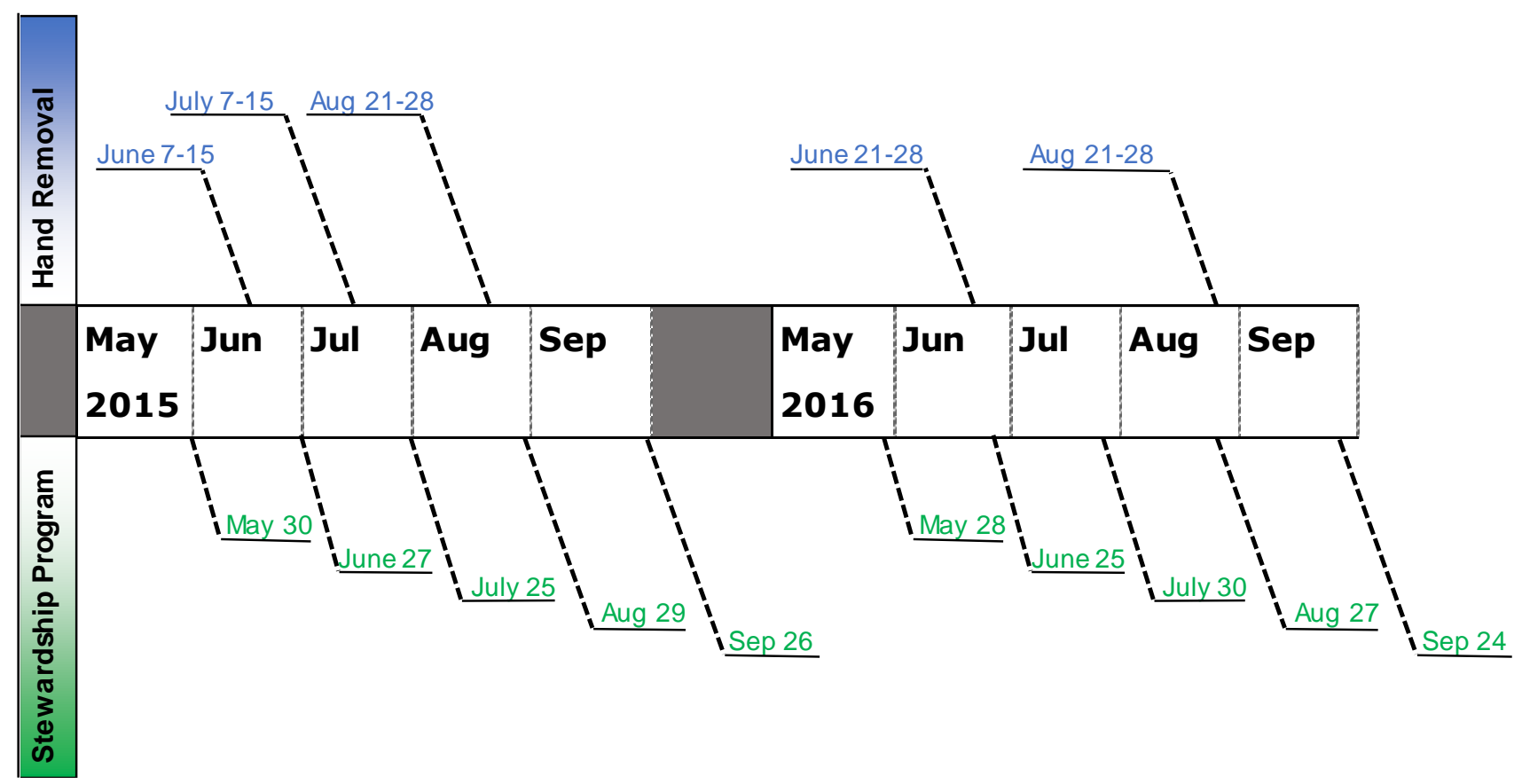

Figure 11. Timeline of future control efforts within the BHW for 2015-2016. "Hand Removal" events are to be carried out by contractor, dates are subject to change. "Stewardship Program" represents Last Saturday in the Wetlands events where surveying and removal of $L$. peploides ssp. montevidensis will occur.

During the active management period of 2015-2016, representatives of the ECNA will begin to explore options for long-term management and ownership outside of the stewardship program.

Currently, the ECNA lacks on-going funding beyond 2016 and is dependent exclusively on the 
longevity of the stewardship program for management. Agencies and organizations who possess funding and expertise are being identified as possible recipients to transfer ownership of the BHW property. In doing so, a natural space would be preserved and maintained by entities that manage environmental systems. Currently, stakeholders are being identified at the Federal, State, City and private levels. Potential recipients will be contacted in the coming months to gauge interest in the acquisition of the BHW property or long-term management.

\section{MISCELLANOUS WORK COMPLETED}

Although priority was given to the L. peploides spp. montevidensis infestation, numerous environmental issues were addressed within the BHW since project establishment. Issues ranged from managing other invasive plants, removing nutria, preserving trees from beaver herbivory and discovering exotic species new to Oregon. All actions were funded by the BHWRP and contributed to the original goals of the project. More detailed information regarding identification and control methods for invasive species within the BHW can be found in the February 2014 update of the BHWRP (Staunch, 2014).

\section{Other Invasive Plants}

During the early months of the "Last Saturday in the Wetlands" events, the BHW contained high water levels which minimized the accessibility for volunteers to actively remove $L$. peploides ssp. montevidensis. While a majority of the wetland habitat was closed to volunteers, labor was focused within the terrestrial portion of the property to remove emerging invasive weeds. To educate and prepare East Columbia residents for removal of noxious weeds, monthly "Invasive Species Spotlights" were published in the East Columbia Neighborhood Newsletter for six months. Each month's article highlighted a different invasive plant (Picture 9). Prior to each event, volunteers were trained through demonstrations for identification and removal of the target terrestrial weeds. 
Upon initial surveys, the most abundant weeds feasible for volunteer removal were Cirsium arvense (Canadian thistle), Cirsium vulgare (bull thistle), Dipsacus fullonum (common teasel), Jacobaea vulgaris (tansy ragwort) and Rubus armeniacus (Himalayan blackberry). All plants removed from the BHW were present on the "Nuisance Plant List" for the City of Portland (City of Portland, 2011). Volunteers were educated on hand removal methods.

Circium arvense, $C$. vulgare, J. vulgaris and D. fullonum were removed by hand and dug up when roots could not be hand pulled.

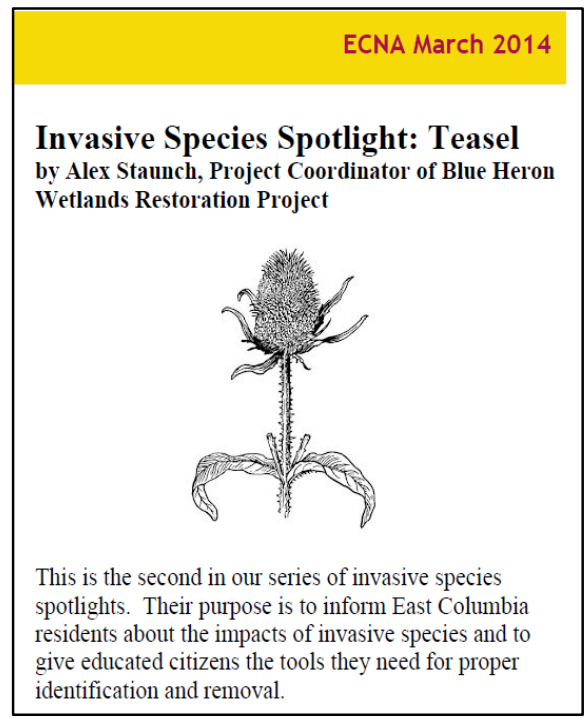

Pic 9. March 2014 installment of "Invasive Species Spotlight".

Canes or stems of $R$. armeniacus were cut with hand tools and portions of the root system were removed with shovels when possible. Cutting of $R$. armeniacus occurred numerous times during the summer of 2014 in response to the constant regeneration of canes.

A total of 1.25 acres of the terrestrial habitat were cleared of the target noxious weeds. The area treated with hand removal was directly southeast of the BP and DP (Figure 2). Immediately after removal, areas that previously possessed high densities of invasive weeds were planted with native forbs and shrubs during the May 31, 2014 stewardship event.

A small population of Iris pseudacarpus (yellow flag iris) composed of six individuals were detected in the $17^{\text {th }}$ street swale $\left(45.5910555^{\circ},-122.6476055^{\circ}\right)$, spreading into the BHW. Since a majority of the I. pseudacarpus were within the swales, the City of Portland was alerted and chemical treatment was not carried out by representatives of the BHWRP. Yet, residents that became aware of the impact and identification of I. pseudacarpus from educational events and "Invasive Species Spotlight" articles periodically harvested flowers and fruits for disposal. During the chemical application of September 26, 2012 and August 8, 2013, the contract crew cut and treated I. pseudacarpus that had 
spread past the boundary of the swale with 5\% glyphosate. As of October 2014, individuals of $I$. pseudacarpus were still present within the $17^{\text {th }}$ St. swale.

\section{Nutria Removal}

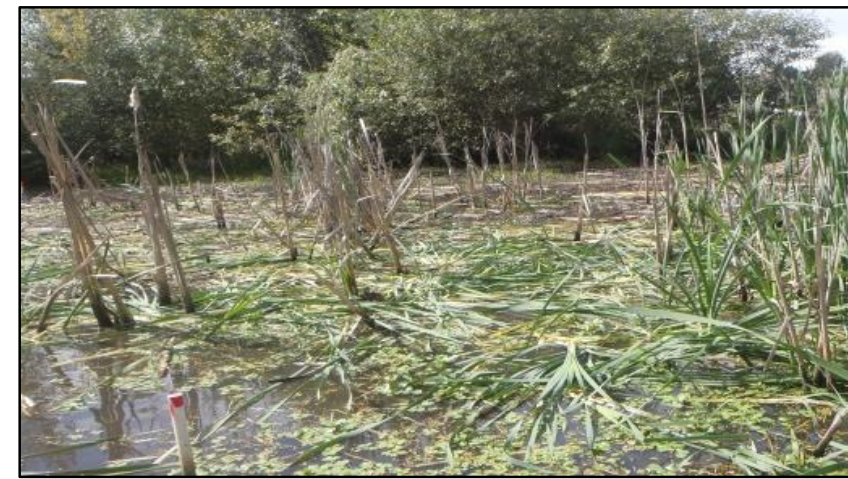

Pic 10. "Nutria eat out" within the cattail stands of the BHW.
Signs of nutria (Myocastor coypus), were noticed within the BHW as early as 2012. There were few burrows detected and minimal herbivory to native vegetation at the time. In spring 2013, the magnitude of impact escalated when multiple burrows occurred within each of the four ponds and cattail (Typha latifolia) populations experienced "nutria eat outs" (Picture 10), when cattails are uprooted in order for nutria to access the succulent roots and rhizomes (Harris and Webert 1962, cited from Carter et al. 1999; Ehrlich, 1962). Native plant regrowth was quickly grazed and populations of nutria were observed by residents (Emma Pletz and Patrick Henry, pers. comm., June 2013). Due to the need to preserve the integrity of the monitoring plots and to allow native plants to colonize open spaces, an extensive trapping program occurred to remove nutria from the BHW. However, it is important to note that nutria grazed on young plants and new growth of L. peploides ssp. montevidensis. Herbivory by nutria did not occur at intensities to reduce spread or substantially decrease plant density (A. Staunch, pers. obs., August 2013).

In summer 2013, live traps were set within the BHW along apparent nutria paths. Live traps were selected in order to prevent harm to non-target domestic cats and dogs that had been observed within the wetland property. After three months of trapping, 21 nutria were captured and removed from the BHW. Nutria were actively caught from July to October, 2013. Traps remained within the wetlands for another five weeks without activity. Traps were removed for the winter and reset in June 2014 for six weeks. No 
nutria were detected and signs of impact were non-existent during the summer of 2014. Nutria may not have been in high densities within the BHW during 2014, but the presence of nutria within the adjacent drainage system of MCDD ensures recolonization is imminent in the coming years (Josh McNamee, pers. comm. July 2013). Classified as unprotected Nongame Wildlife in the State of Oregon (OAR 635044-0132), no permit or license was necessary for trapping and removal. Trapping adhered to the Oregon Furbearer Trapping and Hunting Regulations of the Oregon Department of Fish and Wildlife (OAR 635-50) (OFWS, 2012)

\section{Beaver Caging}

In fall 2013, a North American beaver (Castor canadensis) was first observed within the BHW. Shortly after, a beaver lodge was built in the BP, with dams appearing at points of water flow within the wetlands. Naturally, established trees that were planted during the 1999 enhancement of the BHW were harvested for food and lodge construction (Picture 11). It became a priority of the BHWRP to preserve established trees for the abundant services provided and future seedling recruitment.

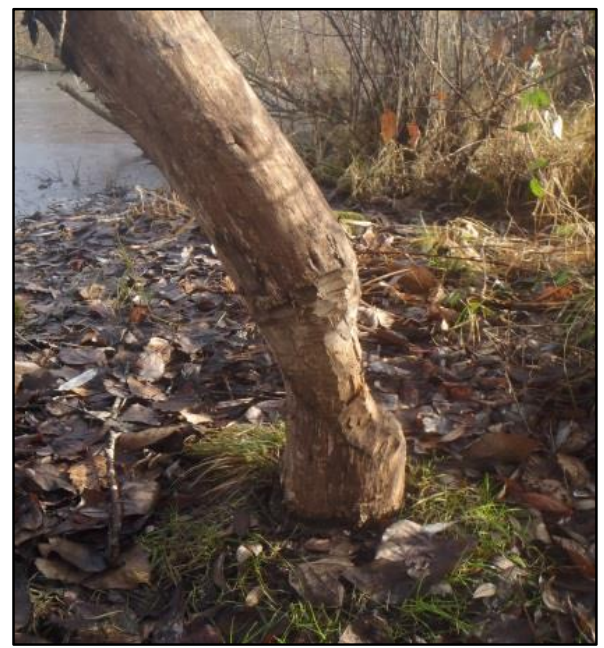

Pic 11. Herbivory by beaver present along the boundary of the BHW.

On June 22, 2014, BES of the City of Portland provided material and a contract crew to cage 70 mature trees. Selected trees were within areas that had experienced heavy herbivory by beaver or acted as a boundary between the BHW and the adjacent drainage ditches. Cages will be maintained by the stewardship program in the coming years.

\section{New Exotic Plant to Oregon}

The discovery of Sagittaria platyphylla (delta arrowhead) within the BHW represented the first known population within the State of Oregon. First believed to be a form of the morphologically plastic 
native Sagittaria latifolia (broadleaf arrowhead), S. platyphylla was first observed in 2013. The aquatic plant was present in groups of five to ten individuals within the WP. In the summer of 2014, the small populations of five to ten had increased to dense stands of 400 to 600 individuals (Picture 12). Samples of the unknown species were sent to numerous authorities of the Alismataceae family and later identified as S. platyphylla by representatives of the Oregon State University and University of Alabama herbaria.

Native to the Southern United States, $S$. platyphylla is a popular ornamental and aquarium plant (Broadhurst and Chong, 2011). Known as a prolific reproducer, S. platyphylla is able to reproduce vegetatively and sexually. Highly viable seeds are produced at rates of 20,000 seeds per plant, able to remain buoyant for up to

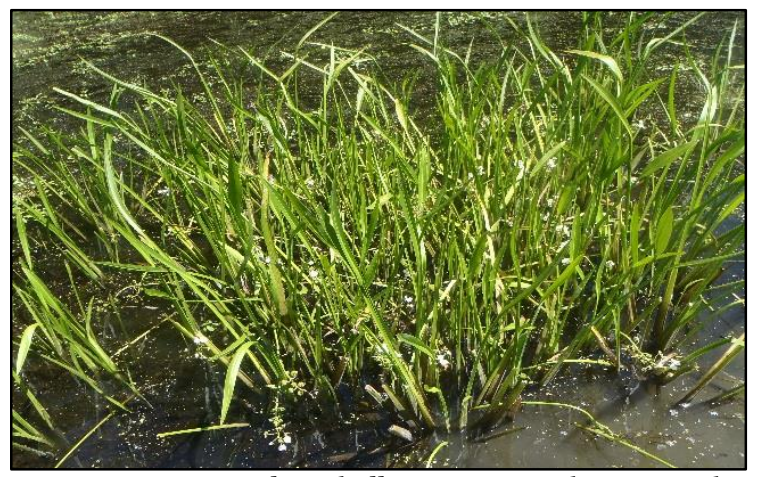

Pic 12. Sagittaria platyphylla growing in dense stands within the BHW.

three weeks (Australian Weeds Committee, 2012). Vegetative propagation can occur from new stem growth and tuber-like corms that are present within the root system. In an experimental setting, populations of S. platyphylla increased from five to 167 stems in a 16 week period. Within the same experiment, the rhizomatic corms, which are able to generate new plant growth increased from zero to 478 during the same 16 week period (Broadhurst and Chong, 2011). The rapid reproduction rate of $S$. platyphylla explains the magnitude of population growth observed within the BHW. Currently, $S$. platyphylla is one of the worst aquatic invaders within Australia and is a Weed of National Significance (Australian Weeds Committee, 2012). In the Pacific Northwest, S. platyphylla is known to be present in one lake in Thurston County, WA (Jenifer Parsons, pers. comm. August, 2014). Sagittaria platyphylla is listed as a quarantine species within the State of Washington (WSNWCB, 2014). The plant's observed 
behavior and invasive qualities forced urgency in addressing the emerging infestation of S. platyphylla at a local and statewide level.

Populations of S. platyphylla were chemically treated on September 11, 2014 with a 3\% glyphosate mix by the BES representative during the same time the control plots of $L$. peploides ssp. montevidensis were treated. Target plants were located primarily within the WP, with some individuals located on the southeastern shore of the BP. To raise awareness of the new, potentially noxious weed, an application was submitted to The Oregon State Weed Board for review and eventual addition of $S$. platyphylla to the State's watch list. Educational fliers were created which highlighted identifiable characteristics of S. platyphylla and potential control methods.

\section{BUDGET \& EXPENSES}

Grants awarded in summer of 2011 totaled $\$ 39,890.00$ with $\$ 33,192.63$ being utilized by the BHWRP from July 15, 2011 to December 31, 2014 (Appendix F). The funds provided by NPNS $(\$ 2,000)$ and EMSWCD $(\$ 16,990)$ were exhausted at the completion date of the project. The remaining $\$ 5,567.01$ from Metro's Nature in Neighborhood's Grant $(\$ 20,000)$ and Intel $(\$ 900)$ remain available to the BHWRP. As of December 2014, the Metro grant was extended to June 30, 2015 to provide assistance in forming a long-term solution for ownership and management of the BHW.

The in-kind contributions from volunteer hours and donations totaled $\$ 43,341.30$, bringing the total cost of the project to $\$ 76,533.93$. In-kind contributions included administrative resources in the form of office space and liability insurance from NPNS, chemical spot-treatment by the Early Detection and Rapid Response Program of the City of Portland, and beaver cages installed by The City of Portland's Watershed Revegetation Program. Professional consulting and involvement in educational events were kindly donated by numerous agencies and organizations throughout the Greater Portland Area and beyond (Table 3.). 
Costs associated with direct control of the L. peploides spp. montevidensis infestation totaled $\$ 9,414.88$ (Table 4.). Cost per acre was calculated from the original range of infestation, 2.409 acres.

Donated in-kind volunteer hours were not included in economic worth.

Table 4. Costs of direct control for L. peploides ssp. montevidensis from July 2011 to December 2014.

\begin{tabular}{|c|c|c|c|c|c|}
\hline Year & Action & Vendor & $\begin{array}{c}\text { Acres } \\
\text { Treated }\end{array}$ & $\begin{array}{c}\text { Total } \\
\text { Cost }\end{array}$ & $\begin{array}{c}\text { Cost Per } \\
\text { Acre }\end{array}$ \\
\hline 2012 & Chemical Application & Contractor & 1.85 & $\$ 969.24$ & $\$ 523.91$ \\
\hline 2013 & Chemical Application & Contractor & 1.8 & $\$ 1,239.14$ & $\$ 688.41$ \\
\hline 2013 & Hand Removal & Contractor & 3.5 & $\$ 1,323.00$ & $\$ 378.00$ \\
\hline 2013 & Wetland Seeding & River Refuge Seeds & 1.85 & $\$ 890.75$ & $\$ 481.49$ \\
\hline 2014 & $\begin{array}{c}\text { Hand Removal } \\
\text { (3 events) }\end{array}$ & Contractor & 2.0 & $\$ 3,472.00$ & $\$ 1,736.00$ \\
\hline 2014 & Hand Removal & PSU Students & 1.1 & $\$ 630.00$ & $\$ 572.73$ \\
\hline 2014 & Hand Removal & Volunteer & 0.5 & - & - \\
\hline 2014 & Chemical Application & City of Portland & 0.6 & - & - \\
\hline 2014 & Wetland Seeding & River Refuge Seeds & 1.85 & $\$ 890.75$ & $\$ 481.49$ \\
\hline \multicolumn{7}{r}{} & & Totals: & $\$ 9,414.88$ & $\$ 3,906.59$ \\
\hline
\end{tabular}

\section{ACKNOWLEDGEMENTS}

Work of the Blue Heron Wetland Restoration Project would not have been possible without the generous fiscal sponsorship from numerous agencies, organizations and private businesses: Metro, East Multnomah Soil and Water Conservation District, North Portland Community Works, and Intel.

Our funding was made possible by letters of support from: Brenda Grewell, USDA; Marla Harrison and Dana Green, Port of Portland; Jason Hatch, North Portland Community Works; Dave Hendricks and Josh McNamee, Multnomah County Drainage District; Rian Hooff, Oregon Invasive Species Council; Joseph Maser, Portland State University; Glenn Miller, Oregon Department of Agriculture; and Dick Shafer, Peninsula II Drainage District. 
Expertise, technical assistance and materials were donated by: Susan Barthel, Mitch Bixby, David Helzer, Dominic Maze and Toby Query, City of Portland; Joseph Buttafuoco, The Nature Conservancy; Sheilagh Diez, Columbia Slough Watershed Council; Scott Gall and Michelle Delepine, West Multnomah Soil and Water Conservation District; Brenda Grewell, USDA; Tom Griffin-Valade, NPNS; Joseph Maser, PSU; Vanessa Morgan-Howard, The Center of Lakes and Reservoirs; Josh McNamee, MCDD; Elaine Stewart, Metro.

Hard work and many hours were provided since 2011 by volunteers of the East Columbia Neighborhood and PSU. Of the 48 volunteers that participated in hard-labor or administrative duties, a special thanks goes to: Emma Pletz, Maryhelen Kincaid, Nancy Harrison, Jim Kincaid, Ron Myers, Patrick Henry, Art Booth, Jeff Brittain, Sam Cimino, Bob Donley, Katie Farmer, Sean Griffin, Sharon Gordan, Kara McInally, Abigail Rincon and Jennifer Wykstra.

Alex Staunch would like to personally thank his academic committee for all the support provided in the fulfillment of the Master of Environmental Management Degree at Portland State University: Mitch Bixby, Tom Griffin-Valade, Dr. Joseph Maser, and Dr. Mark Sytsma. 


\section{REFERENCES}

Anonymous. 2007. Aquaneat herbicide label. Burr Ridge, IL: Nufarm, Inc. p. 11 http://www.cdms.net/LDat/Id5NE011.pdf. Accessed: December 12, 2014.

Anonymous. 2009a. Element 3A herbicide label. Indianapolis, IL: Dow Agrosciences, LLC. http://www.ctahr.hawaii.edu/deFrankJ/481_2011/Projects_2011/pdf_labels_for_projects_2011/Element_ 3A_triclopyr_08242011.pdf. Accessed: December 12, 2014

Anonymous. 2009b. Aquamaster herbicide label. St. Louis, MO: Monsanto Company. p. 8. http://www.cdms.net/LDat/Id4BL017.pdf. Accessed: December 12, 2014.

Australia Weeds Committee. 2012. "Weeds of National Significance. Sagittaria (Sagittaria platyphylla) Strategic Plan". Australian Weeds Committee, Canberra.

Broadhurst, L. and C. Chong. 2011. "Examining clonal propagation of the aquatic weed Sagittaria platyphylla" Rural Industries Research and Development Corporation. 11/020.

Carter, J. Foote, A. and A. Johnson-Randall. 1999. "Modeling the effects of nutria (Myocastor coypus) on wetland loss. Wetlands. 19(1):209-219.

City of Eugene, Open Parks Division. 2013. "Invasive Ludwigia hexapetala Management Plan".

City of Portland, Bureau of Planning. 1997. "Exhibit E". Declaration of Common Open Space Maintenance Agreement. Portland, OR.

City of Portland, 2011. "Portland Plant List". Accessible: https://www.portlandoregon.gov/auditor/34460?a=322280

Champion, P., James, T. and E. Carney. 2008. "Evaluation of triclopyr trimethylamine for the control of wetland weeds". New Zealand Plant Protection. 61: 374-377.

Dandelot, S. 2004. "Les Ludwigia spp. invasvies du sud de la France: historique, biosystematique, biologie et Ecologie. These de doctorat de l'Universite de Aix-Marseille: 207.

Dandelot, S., Verlaque, R., Dutartre, A. and A. Cazaubon. 2005. "Ecological, dynamic and taxonomic problems due to Ludwigia (Onagraceae) in France". Hydrobiologia. 55(2): 1-6.

Dandelot, S., Robles, C., Pech, N., Cazaubon, A. and R. Verlaque. 2008. "Allelopathic potential of two invasive alien Ludwigia spp". Aquatic Botany. 88: 311-316.

D'Antonio, C and J. Chambers. 2006. "Using ecological theory to manage or restore ecosystems affected by invasive plant species. Foundations of restoration ecology. 260-279.

DiTomaso, J.M. and E.A. Healy. 2003. Aquatic and Riparian Weeds of the West. University of California. pp 249. 
Dutartre, A. 1988. Nuisances occasionnees par les plantes aquatiques imputables aux vegetaux. Analyses de Cas. In Ann. ANPP, 15eme Conferences du COLUMA, Versailles, ANPP (eds), Paris, 1075-1082.

Dutartre, A., Bertrin, V. and C. Laplace-Treyture. 2005. "Suivi scientifique et technique des jussies (Ludwigia spp): Evaluation des biomasses produites, anse Sud Est de l'etang de Leon. Programme pluriannuel de gestion des plantes aquatiques envahissantes du Conseil General des Landes, 2003-2005". Cemagref. Unite de Recherche Qualite des Eaux. Final Report.

Dutartre, A., Haury, J., Dandelot, S., Coudesre, J., Ruaux, B., Lambert, E., Le Goffe, P., and MJ Menozzi. 2007. Les Jussies: caracterisation des relations entre sites, population et activites humaines. Implication pour la gestion. Programme de recherché 'Invasions Biologiques' 2003-2006, Final report. Cemagref.

Ehrlich, S. 1962. Two experiments in inducing nutria aggregation in unfenced artificial ponds. Hydrobiologia. 19:316-333.

Harris, V. and F. Webert. 1962. "Nutria feeding activity and its' effect on marsh vegetation in southwestern Louisiana". USFWS, Washington, DC, USA. Special Scientific Report Wildlife 64.

Hoch, P. and B. Grewell. 2012. "Ludwigia in Jepsen Flora Project (eds.)". Jepson eFlora. http.??ucjeps.berkeley.edu/cgi-bin/get_IJM.pl?tid=51358, Accessed on Jan 192015.

Hussner, A. 2010. "Growth response and root system development of the invasive Ludwigia grandiflora and Ludwigia peploides to nutrient availability and water level. Fundam. Appl. Limnol., Arch. Hydrobiol. 177(3): 189-196.

Knoche, M. and M. Bukovac. 1993. Interaction of surfactant and leaf surface in glyphosate absorption. Weed Science. 41 (1): 87-93.

Lambert, E., Dutartre, A., Coudrese, J. and J. Haury. 2010. "Relationships between the biomass production of invasive Ludwigia species and physical properties of habitats in France". Hydrobiologia. 656: 173-186.

Metro, 2014. "Nature in Neighborhoods restoration \& community stewardship grants full application handbook". www.oregonmetro.gov.

Oregon Department of Agriculture. 2011a. "Noxious weed quarantine". Issued effective: September 9, 2011. www.oregon.gov/ODA/PLANT/603_052_1200.shtml. Accessed: December 11, 2013

Oregon Department of Agriculture. 2011b. "Water primrose. Ludwigia spp. aquatic invader!". [Brochure]. Salem, OR. Oregon Department of Agriculture.

Oregon Department of Agriculture. 2014. "Noxious weed policy and classification system 2014". Oregon Department of Agriculture Noxious Weed Control Program. pg. 6.

Oregon Fish \& Wildlife Service. 2012. "Oregon furbearer trapping and hunting regulations. July 1, 2012 through June 20, 2014." Accessible: http://www.predatordefense.org/docs/OR_Furbearer_Regulations.pdf 
Pacific Western Homes, Inc. 1997. "Covenants, conditions and restrictions for Blue Heron Meadows. A residential Development. City of Portland, Multnomah County, Oregon". County Records. Multnomah County, Oregon. December 11, 2011.

Raven, P. and W. Tai. 1979. “Observation chromosomes in Ludwigia (Onagraceae). Annals of the Missouri Botanical Garden. 66: 862-879.

Richardson, D. Pysek, P., Rejmanek, M., Barbour, M., Panetta, F., and C. West. 2000. "Naturalization and invasion of alien plants: concepts and definitions". Diversity and Distribution. 6: 93-107.

Rejmankova, E. 1992. "Ecology of creeping macrophytes with special reference to Ludwigia peploides (H.B.K) Raven". Aquatic Botany. 43(3): 143-148.

Rouse, C., and P. Dittmar. "Factors affecting herbicide use in fruits and vegetables". Institute of Food and Agricultural Sciences. Publication \#HS1219.

Ruaux, B. 2009. "Sexual reproduction of two alien invasive Ludwigia (Onagraceae) on the middle Loire River, France". Aquatic Botany. 90(2): 143-148.

Saint-Macary, I. 1998. "Dynamique de Ludwigia peploides au Marais d'Orx". Memorie de DESS. Dynamique des ecosystem aquatiques, Universite des Pau et des Pays de L'Adour. Syndicat mixte pour la gestion et l'amenagement du Marais D’Orx. 23.

Sears, A., Meisler, J. and L. Verdone. 2006. "Invasive Ludwigia management plan for Laguna de Santa Rosa, Sonoma County, California". Laguna de Santa Rosa Foundation. Invasive Ludwigia Management Plan.

Smida, I., Charpy-Roubaud, C., Cherif, S., Torre, F., Audran, G., Smiti, S. and J. Petit. 2015. "Antibacterial properties of extracts of Ludwigia peploides subsp. montevidensis and Ludwigia grandiflora subsp. hexapetala during their cycle of development." Aquatic Botany. 121: 39-45

Sprecher, S., and A. Stewart. 1995. "Triclopyr effects on peroxidase activity in target and non-target aquatic plants." J. Aquatic Plant Management. 33: 43-48.

Staunch, A. 2014. "Eradication of Ludwigia peploides ssp. montevidensis from the Blue Heron Wetlands of Portland, OR. Project Update: February 1, 2014." ECNApdx.com. Accessible at: http://www.ecnapdx.com/images/bhwrp/Project_Update_2.13.1.pdf

Staunch, A., Donley, R., Griffin, S., Mclnally, and A. Rincon. 2011. "Invasive Ludwigia peploides ssp. montevidensis eradication plan for the Blue Heron Wetlands, NE Portland, OR. Accessible at: http://www.ecnapdx.com/images/bhwrp/Management_Final_7-12_1-3.pdf

Stiers, I., Chrohain, N., Josens, G. and L. Triest. 2011. "Impact of three aquatic invasive species on native plants and macroinvertebrates in temperate ponds." Biological Invasions. 12: 2715-2726.

Thouvenot, L., Haury, J. and G. Thiebaut. 2013a. "A success story: Water primroses, aquatic plant pests". Aquatic Conservation: Marine and Freshwater Ecosystems. 23: 790-803. 
Thouvenot, L., Haury, J. and G. Thiebaut. 2013b. "Seasonal plasticity of Ludwigia grandiflora under light and water depth gradients: An outdoor mesocosm experiment". Flora. 208(7): 430-437.

Thouvenot, L., Puech, C., Martinez, L., Haury, J., and G. Thiebaut. 2013c. "Strategies of the invasive macrophyte Ludwigia grandiflora in its introduced range: Competition, facilitation or coexistence with native and exotic species?". Journal of Aquatic Ecology. 107: 8-16.

Trimble.com, 2014. “GNSS Planning Online". http://www.trimble.com/gnssplanningonline/\#/Settings. Last Accessed: August 14, 2014.

Trewartha, G.T. 1968. An introduction to climate, 4th Edition. Mc Grawhill Kogakusha, LTD. pp. 408.

USGS, 2015. "City of Portland HYDRA Rainfall Network". Rain gauge location: 7660 NE Airport Way. Portland, OR 97218. Oregon Water Science Center. http://or.water.usgs.gov/non-usgs/bes/. Accessed: January 27, 2013.

Wagner, W., Hoch, P. and P. Raven. 2007. "Revised classification of the Onagraceae." Sytematic Botany Monographs. 83: 1-240.

Walker, B., Kinzig, A., and J. Langridge. "Original articles: plant attribute diversity, resilience, and ecosystem function: The nature and significance of dominant and minor species". Ecosystems. 2(2): 95-113.

Washington State Noxious Weed Control Board. (2010). Noxious Weeds: Quarantine List. Accessible: http://www.nwcb.wa.gov/searchresultsquarantine.asp

Wilson, J. 1988. "A review of evidence on the control of root:shoot ratio, in relation to models. Annals of Botany. 61: 433-449.

Zardini, E., Gu, H. and P. Raven. 1991a. "On the separation of 2 species within the Ludwigia uruguayensis complex (Onagraceae)". Systematic Botany. 16: 242-244.

Zardini, E., Peng, C. and P. Hoch. 1991b. "Chromosome numbers in Ludwigia section Oligospermum and section Oocarpon (Onagraceae)". Taxon. 40: 221-230.

Zotos, A. Sarika, M., Lucas, E. and P. Dimopoulos. 2006. "Ludwigia peploides subsp. montevidensis, a new alien taxon for the flora of Greece and the Balkans". J. of Biological Research. 5(4): 71-78. 


\section{APPENDICES}

\section{A. Acronyms}

BES: Bureau of Environmental Services

BHW: Blue Heron Wetlands

BHWRP: Blue Heron Wetland Restoration Project

BP: Big Pond

CCR: Covenants, conditions and restrictions

DP: Donut Pond

DM: Dry mass

ECNA: East Columbia Neighborhood Services

EMSWCD: East Multnomah Soil and Water Conservation District

EP: East Pond

MCDD: Multnomah County Drainage District

NPNS: North Portland Neighborhood Services

ODA: Oregon Department of Agriculture

PSU: Portland State University

USDA: United States Department of Agriculture

USGS: United States Geological Survey

WP: West Pond

sp.: Particular species of a genus

spp.: Numerous species of a genus

ssp.: Subspecies 


\section{B. Planting List}

Compiled list of all trees, shrubs and forbs planted by date. Planting occurred through volunteer based events. The 2013 Blue Heron Wetland Volunteer Day established 202 plants on the degraded Ludwigia biomass present within the wetlands. The "Last Saturday" event established 240 plants within areas that experienced removal of Himalayan blackberry. Mitigation planting on November 15, 2014 occurred in response to the removal of trees by residents within the BHW property.

\begin{tabular}{|c|c|c|c|c|c|}
\hline \multicolumn{6}{|c|}{ Planting List: Blue Heron Wetlands } \\
\hline Date Planted & Event & Common Name & Scientific Name & Type & Quantity \\
\hline 20-Mar-13 & 2013 Volunteer Day & Red Osier Dogwood & Cornus sericea & Shrub & 10 \\
\hline 20-Mar-13 & 2013 Volunteer Day & Sitka Willow & Salix sitchensis & Shrub & 10 \\
\hline 20-Mar-13 & 2013 Volunteer Day & Oregon Grape & Mahonia aquifolium & Shrub & 8 \\
\hline 20-Mar-13 & 2013 Volunteer Day & Dwarf Oregon Grape & Mahonia nervosa & Shrub & 15 \\
\hline 20-Mar-13 & 2013 Volunteer Day & Pacific Ninebark & Physocarpus capitatus & Shrub & 10 \\
\hline 20-Mar-13 & 2013 Volunteer Day & Douglas Spirea & Spiraea douglasii & Shrub & 8 \\
\hline 20-Mar-13 & 2013 Volunteer Day & Indian Plum & Oemleria cerasiformis & Shrub & 10 \\
\hline 20-Mar-13 & 2013 Volunteer Day & Mock Orange & Philadelphus lewisii & Shrub & 20 \\
\hline 20-Mar-13 & 2013 Volunteer Day & Kinnikinnick & Arctostaphylos uva-ursi & Shrub & 10 \\
\hline 20-Mar-13 & 2013 Volunteer Day & Yellow Eyed Grass & Sisyrincum californicum & Forb & 36 \\
\hline 20-Mar-13 & 2013 Volunteer Day & P. Bleeding Heart & Dicentra formosa & Forb & 15 \\
\hline 20-Mar-13 & 2013 Volunteer Day & Red Columbine & Aquilegia canadensis & Forb & 20 \\
\hline 20-Mar-13 & 2013 Volunteer Day & Common Camas & Camasia leichttinii & Forb & 10 \\
\hline 20-Mar-13 & 2013 Volunteer Day & Beach Strawberry & Fragaria chiloensis spp. pacifica & Forb & 20 \\
\hline 31-Мay-14 & Last Saturday Event & Salmon Berry & Rubus spectabilis & Shrub & 30 \\
\hline 31-Мay-14 & Last Saturday Event & Red Osier Dogwood & Cornus Stolinifera & Shrub & 30 \\
\hline 31-May-14 & Last Saturday Event & Flowering Currant & Ribes Sanquineum & Shrub & 20 \\
\hline 31-Мay-14 & Last Saturday Event & Nootka Rose & Rosa Nutkana & Shrub & 10 \\
\hline 31-May-14 & Last Saturday Event & Red Alder & Alnus rubra & Tree & 20 \\
\hline 31-May-14 & Last Saturday Event & Western Crabapple & Malus fusca & Arb. Shrub & 20 \\
\hline 31-Мay-14 & Last Saturday Event & Pacific Willow & Salix lasiandra & Tree & 20 \\
\hline 31-May-14 & Last Saturday Event & Thimbleberry & Rubus parvilflorus & Shrub & 20 \\
\hline 31-Мay-14 & Last Saturday Event & Twinberry & Lonicera involucrata & Shrub & 20 \\
\hline 31-May-14 & Last Saturday Event & Mock Orange & Philadelphu lewisii & Shrub & 15 \\
\hline 31-May-14 & Last Saturday Event & Pacific Ninebark & Physocarpus capitatus & Shrub & 20 \\
\hline 31-May-14 & Last Saturday Event & Oceanspray & Holodiscus discolor & Shrub & 15 \\
\hline $15-$ Nov-14 & Mitigation Planting & Red Alder & Alnus rubra & Tree & 8 \\
\hline $15-$ Nov-14 & Mitigation Planting & Cascara & Rhamnus purshiana & Tree & 2 \\
\hline & & & & Total: & 452 \\
\hline
\end{tabular}




\section{Select Plot Photos}

\section{Pilot Test, Doughnut Pond: 0.75\% Glyphosate (Plot G1)}

Monitoring plot for pilot study, received $0.75 \%$ glyphosate application on Sept. 28, 2011. Signs of senescence occurred less than a week after application. Ludwigia within other $0.75 \%$ glyphosate applied plots did not respond as quickly to treatment. In June 2012, Blackened and denuded stems from herbicide application were visible, with full recovery of sprayed plant matter occurring by August 2012.

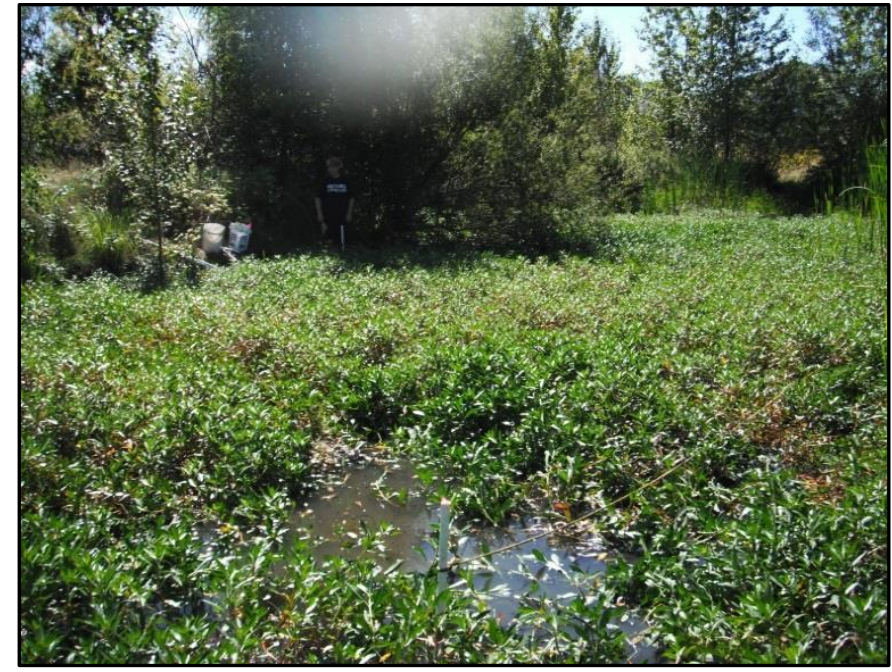

Pre-Treatment: September 2, 2011

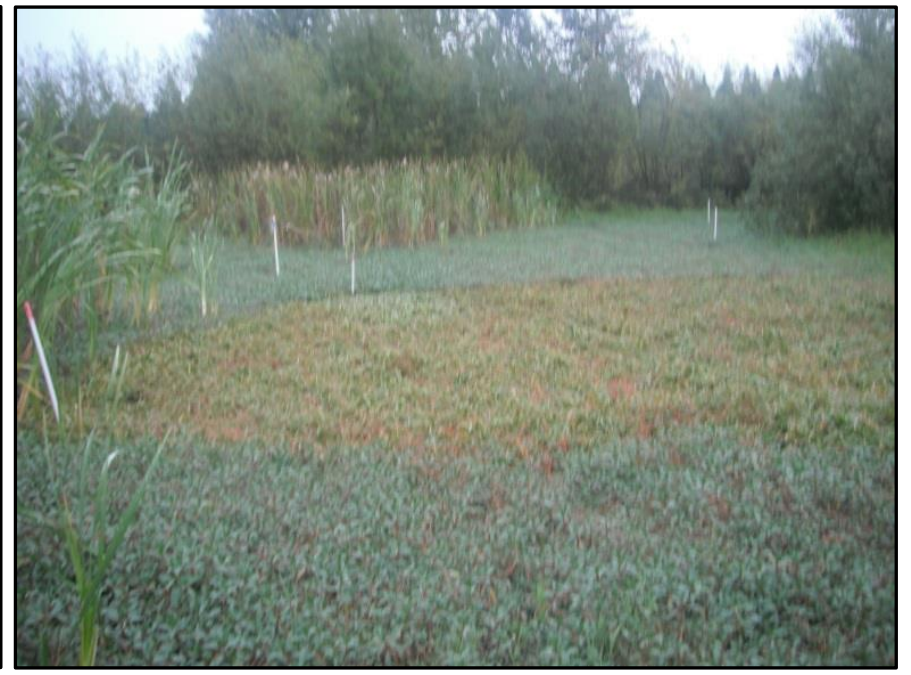

October 3, 2011 Alternate photo angle

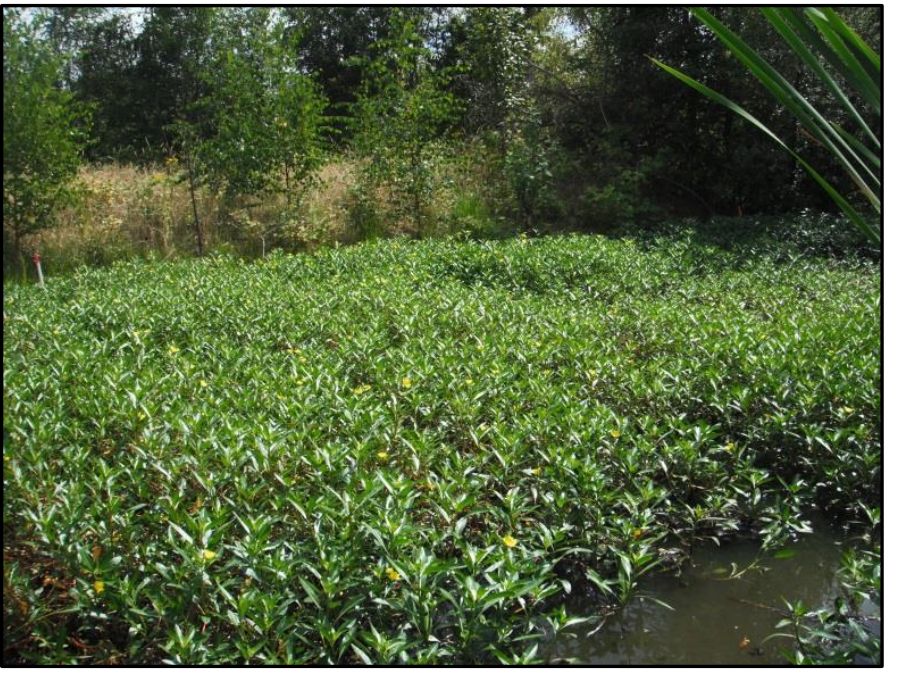

August 8, 2012

June 19, 2012 


\section{Pilot Test, Doughnut Pond: 1.0\% Triclopyr (Plot T1)}

Monitoring plot for pilot study, received 1.0\% triclopyr application on Sept. 28, 2011. Ludwigia demonstrated rapid senescence after application, with reestablishment occurring one year after application.

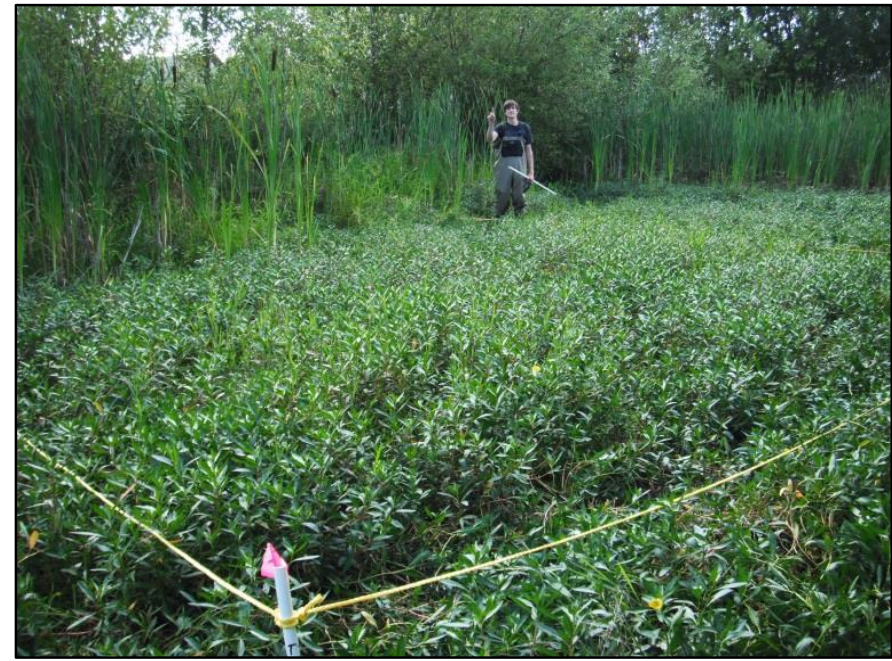

Pre-Treatment: September 2, 2011

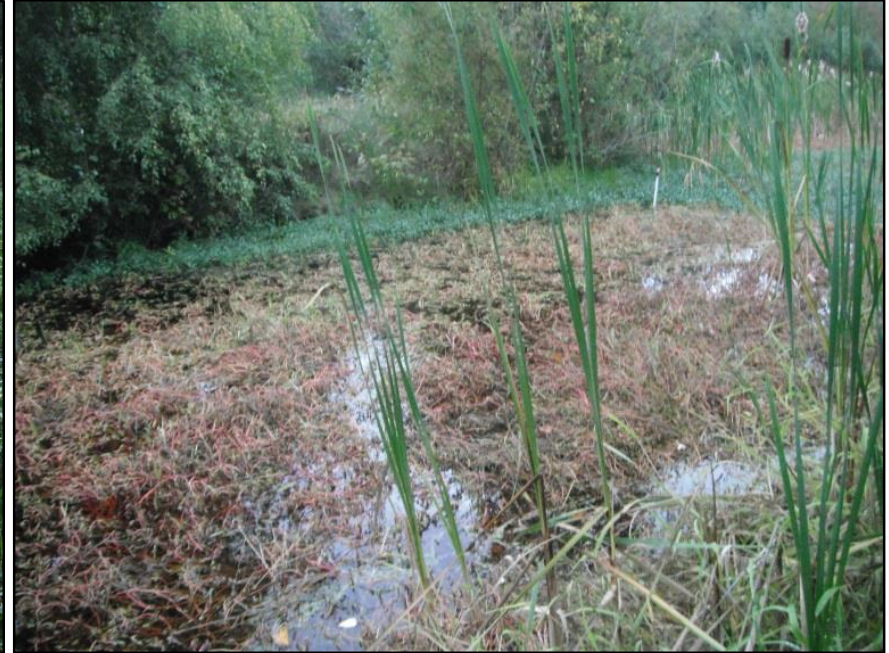

October 10, 2011

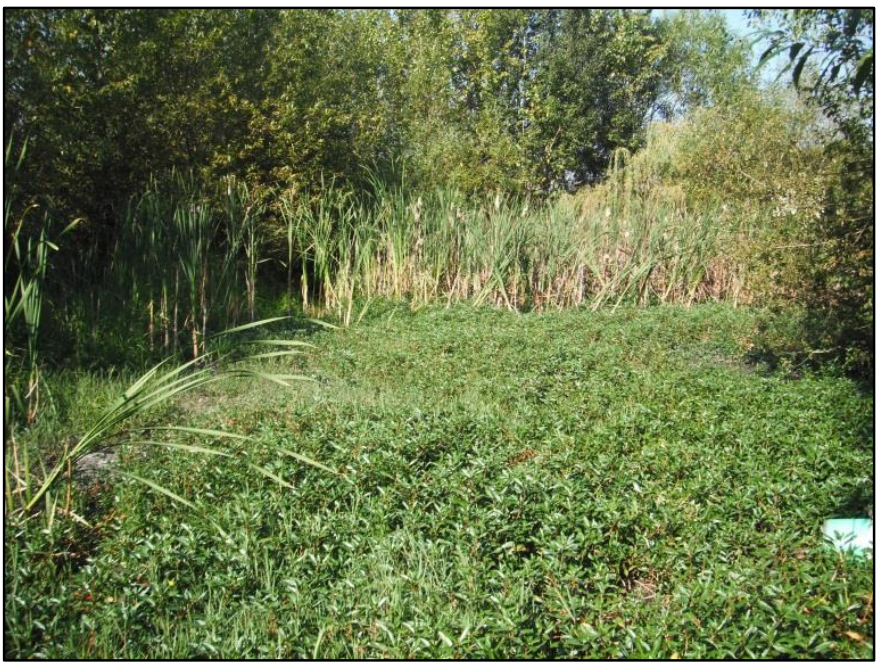

September 18, 2012 


\section{$\underline{\text { Pilot Test, Doughnut Pond: Control (Plot C2) }}$}

Monitoring plot for pilot study. Control plots received no chemical treatment. Ludwigia demonstrated natural senescense in fall 2011, with uniform emergence and growth in spring and summer of 2012.

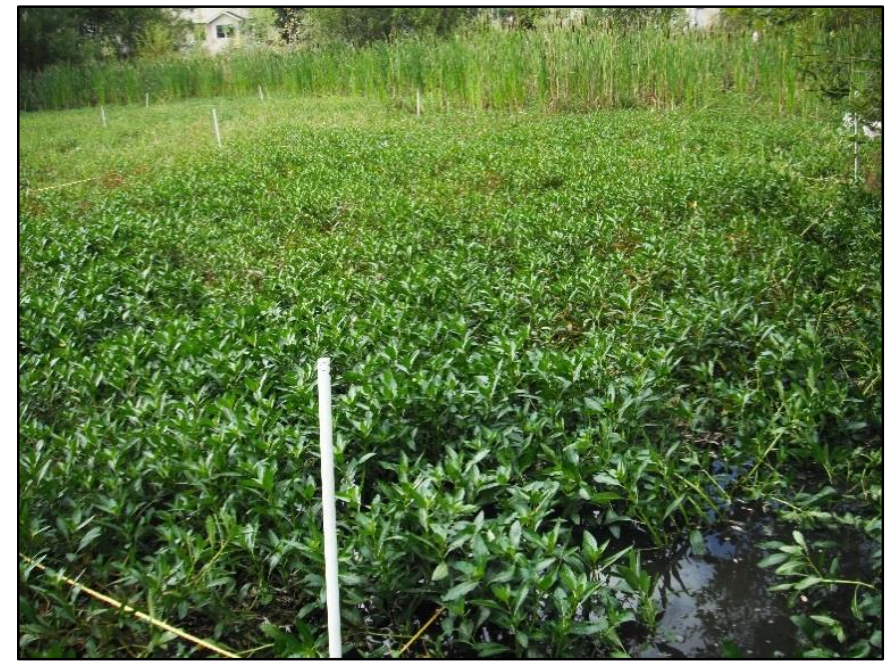

Pre-Treatment: September 2, 2011

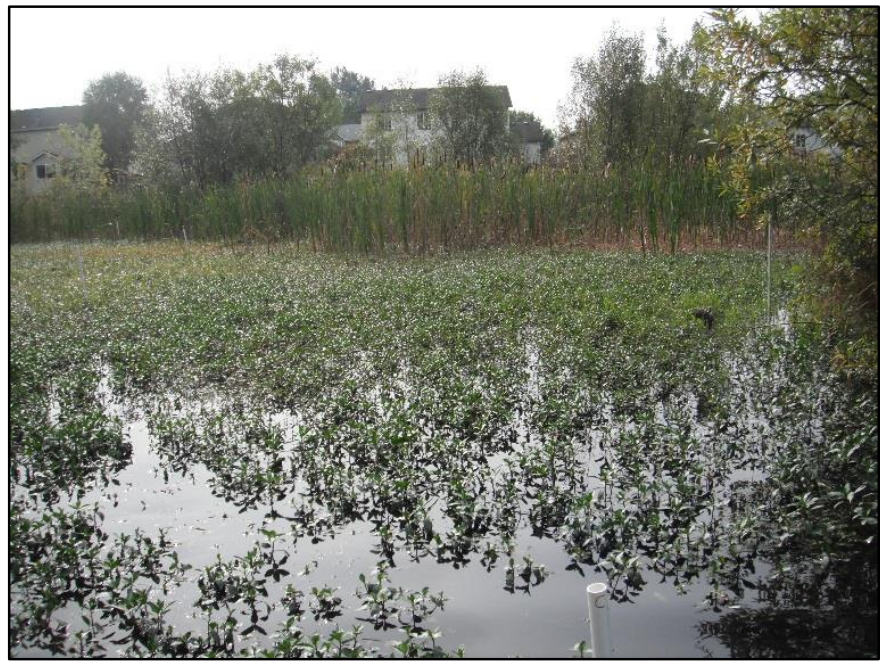

October 15, 2011

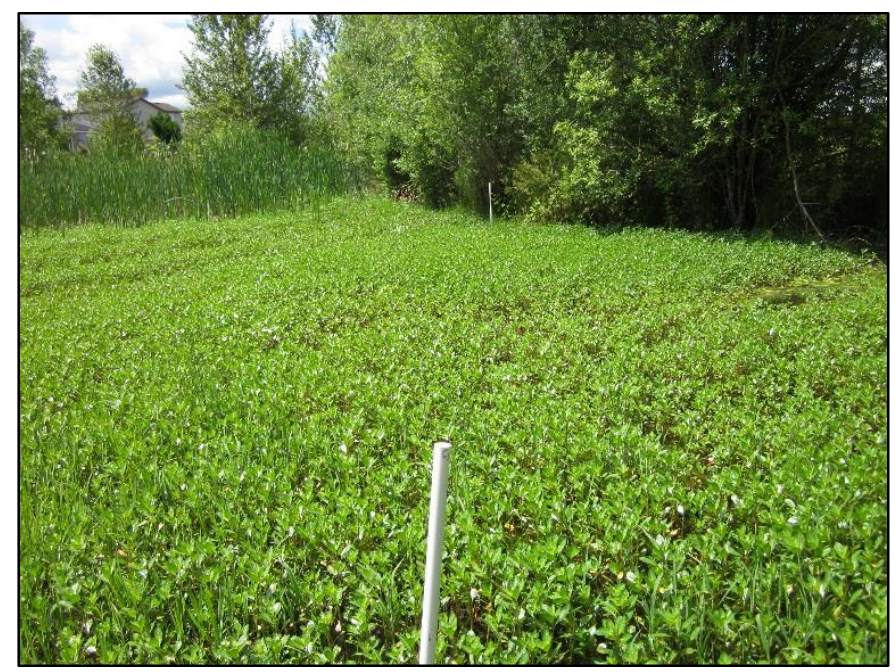

June 19, 2012

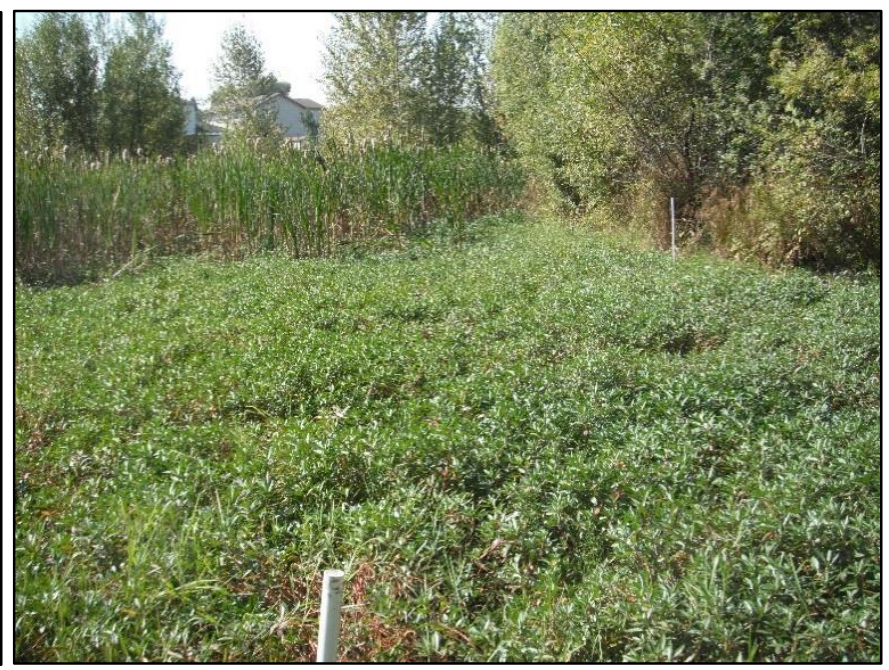

September 18, 2012 


\section{Full Chemical Application, Doughnut Pond: Control (Plot C2)}

Control plot within Doughnut Pond during duration of 3\% glyphosate application. Adjacent areas were treated and boundary of control plot is clearly visible. In 2014, L. peploides ssp. montevidensis spread outwards, occupying areas treated and cleared.

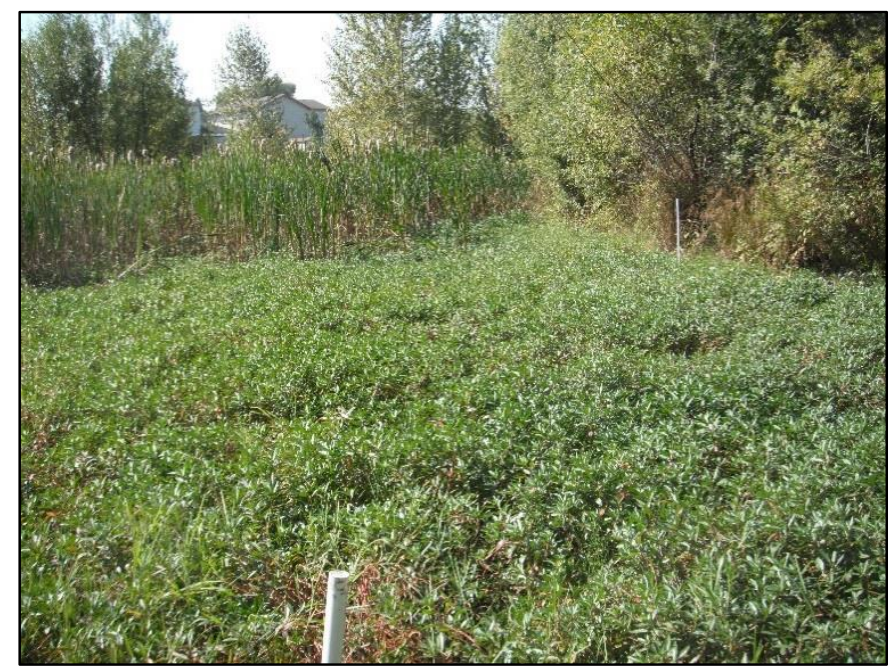

September 18, 2012

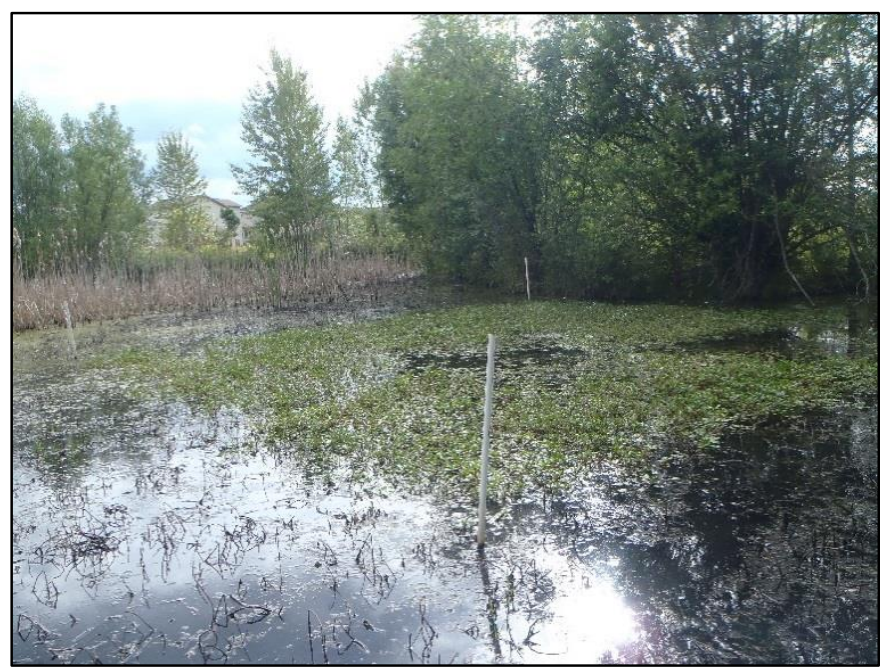

June 20, 2013

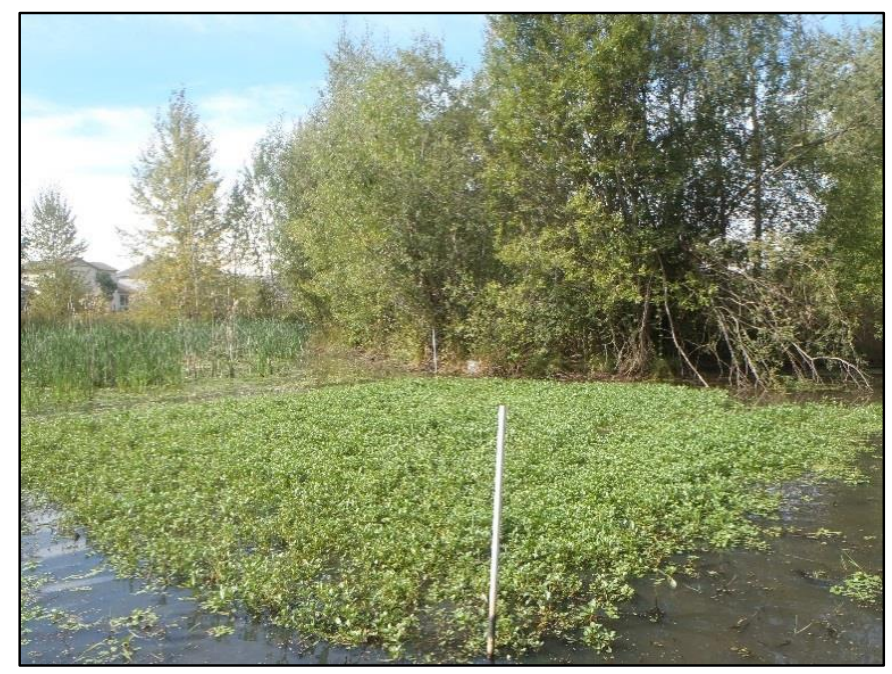

September 20, 2013

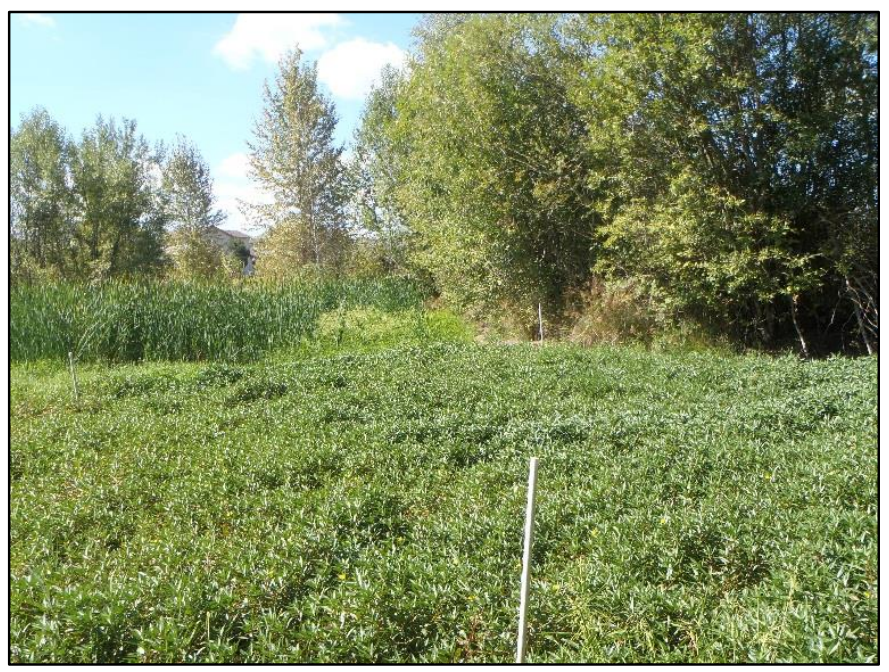

September 9, 2014 


\section{Full Chemical Application, Doughnut Pond: 3\% Glyphosate (Plot A3)}

Monitoring plot applied with 3\% glyphosate on September 26, 2012 and August 8, 2013. Presence of L. peploides ssp. montevidensis greatly was greatly reduced by August 2013, with other plant species colonizing exposed soils by September 2014.

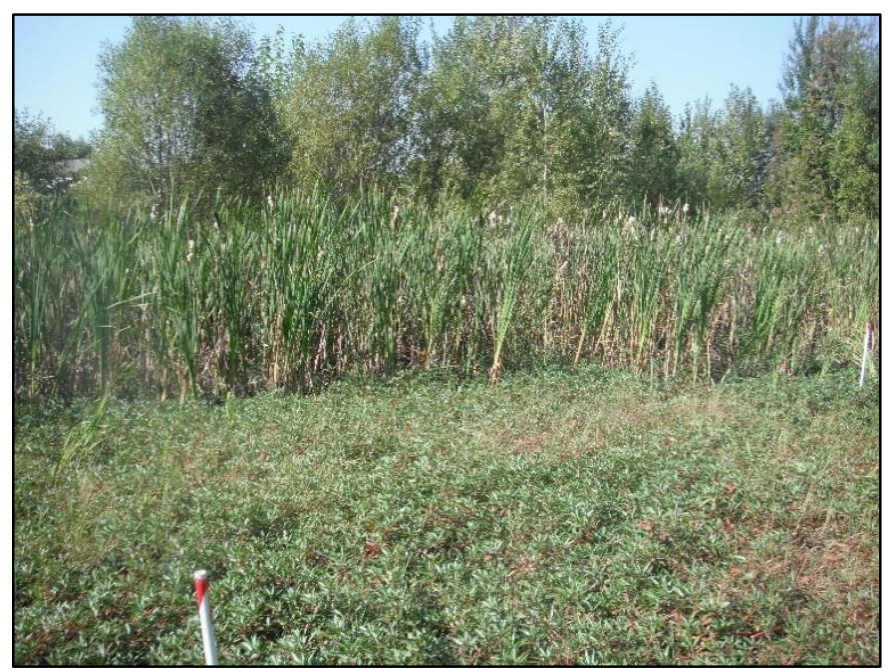

September 18, 2012

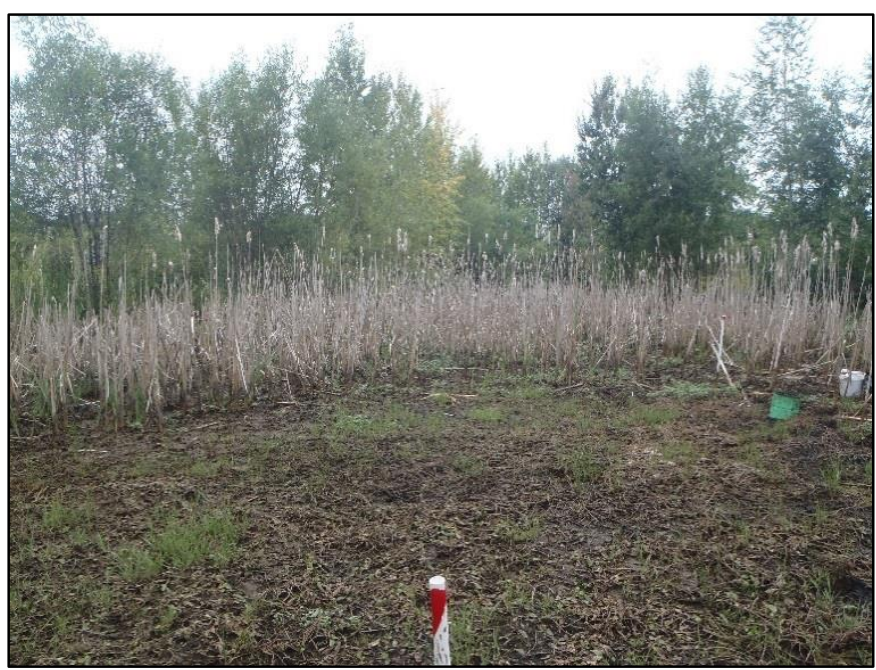

August 2, 2013

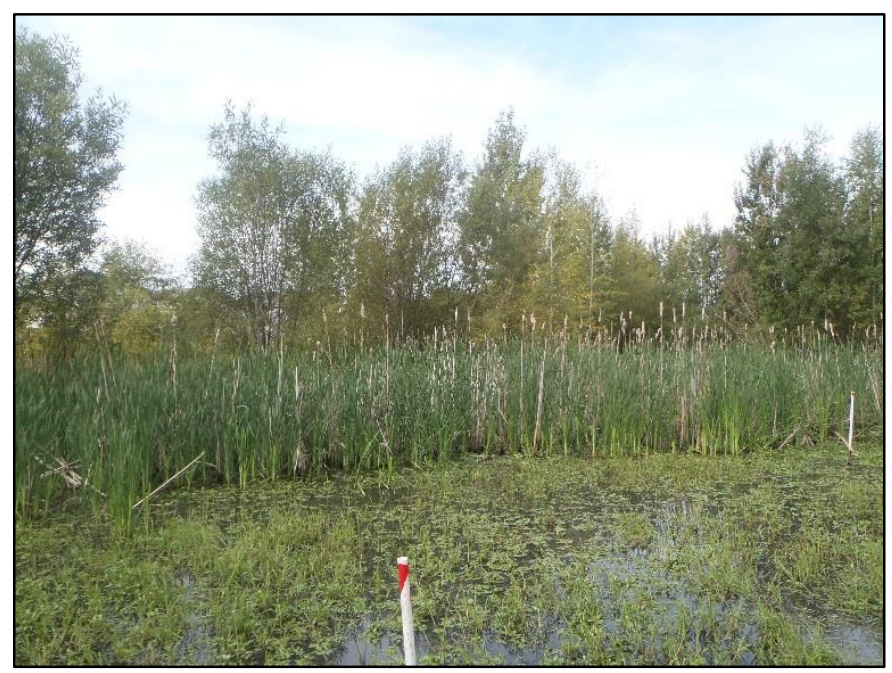

September 20, 2013

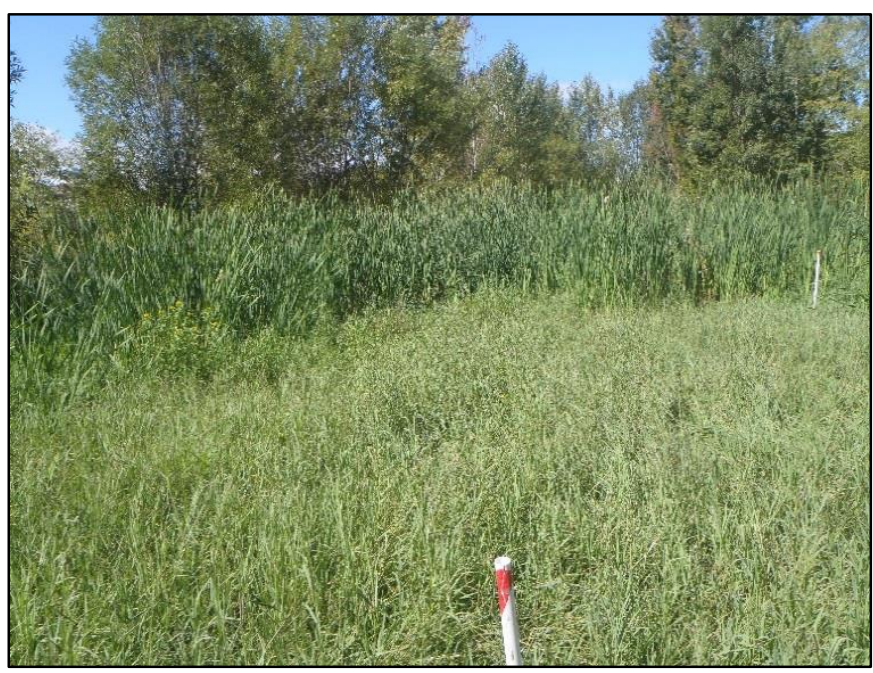

September 9, 2014 


\section{Full Chemical Application, Doughnut Pond: 3\% Glyphosate (Plot A6)}

Monitoring plot applied with 3\% glyphosate on September 26, 2012 and August 8, 2013. Chemical application provided open water habitat throughout 2013. In the summer of 2014, an initial small presence of L. peploides ssp. montevidensis quickly increased in density and area, returning the plot to a monoculture.

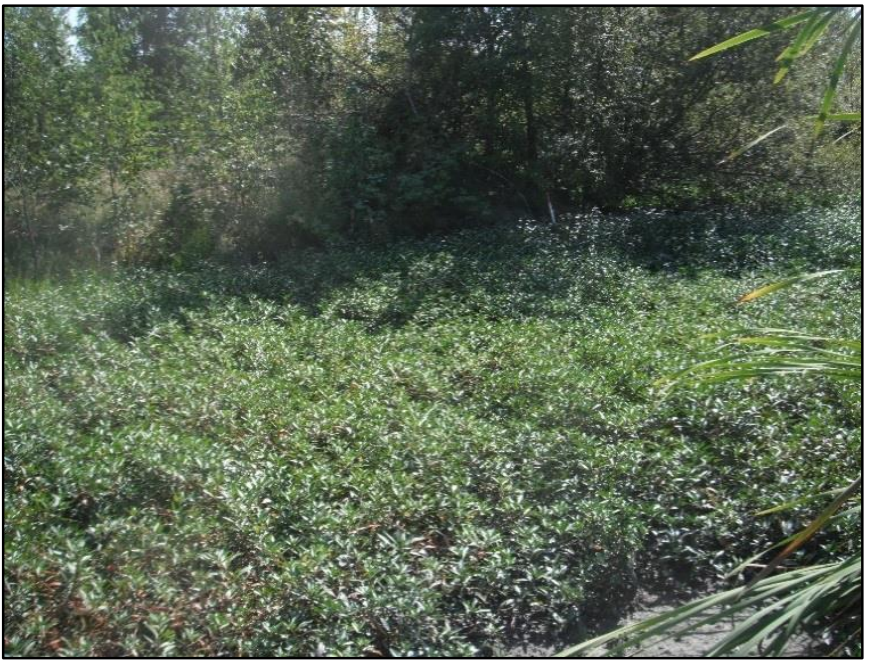

September 18, 2012

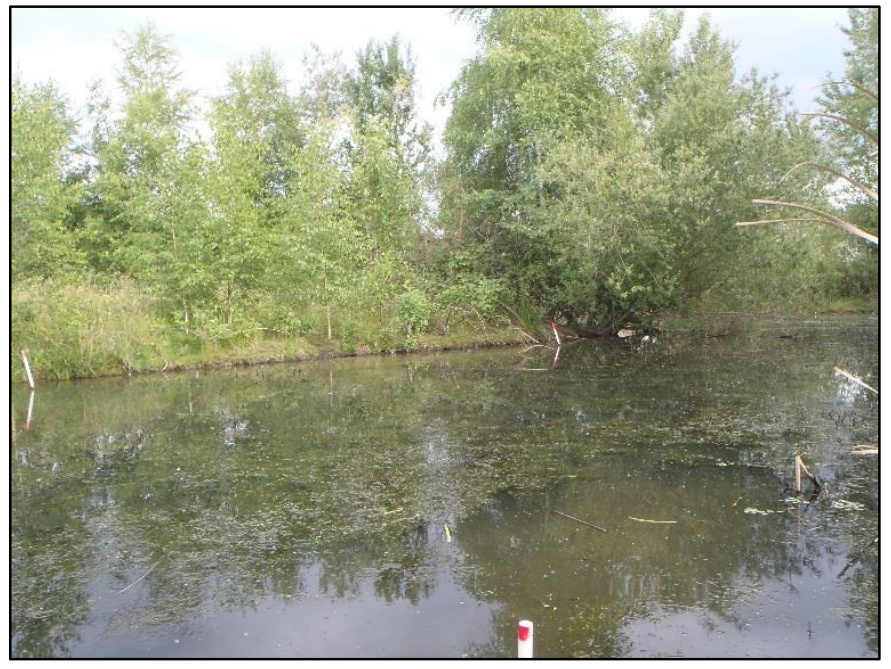

June 20, 2013

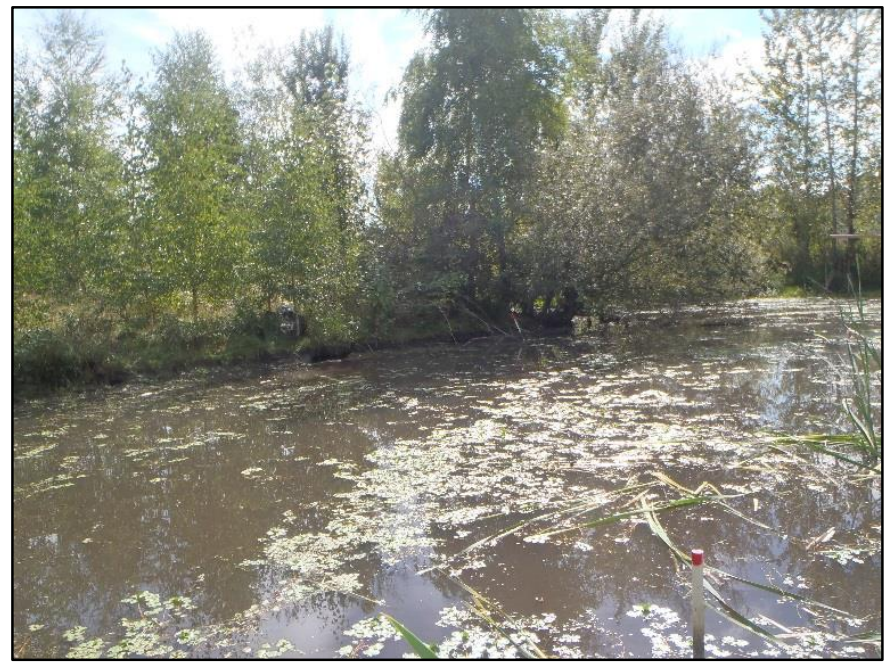

September 20, 2013

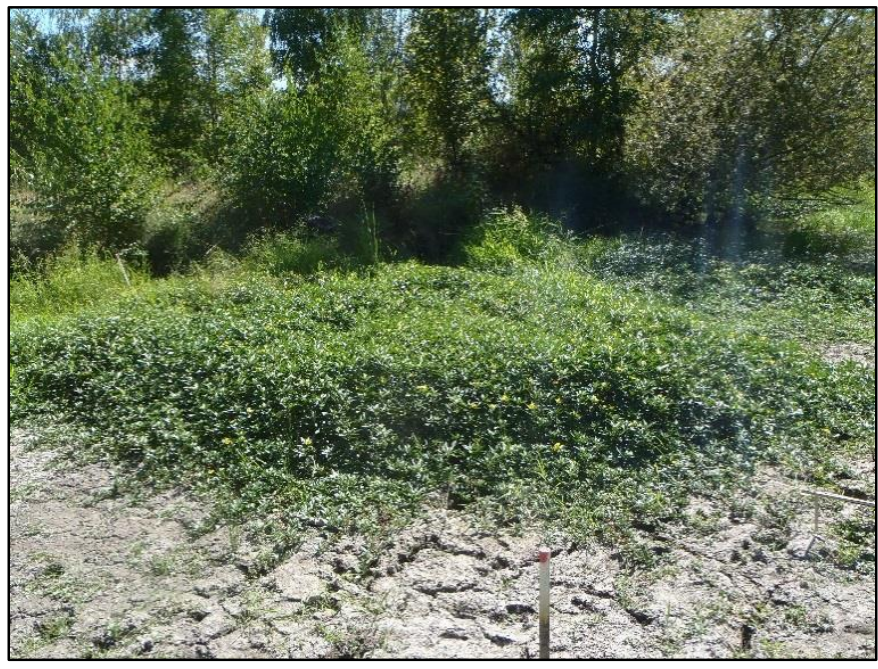

September 9, 2014 


\section{Full Chemical Application, Doughnut Pond: 3\% Glyphosate (Plot A4)}

Monitoring plot applied with 3\% glyphosate on September 26, 2012 and August 8, 2013. Chemical application of 2012 did not significantly reduce the presence of L. peploides ssp. montevidensis along the bank area by August 2, 2013. The 2013 application greatly reduced $L$. peploides ssp. montevidensis and allowed colonization by $P$. distichum and L. oryzoides.

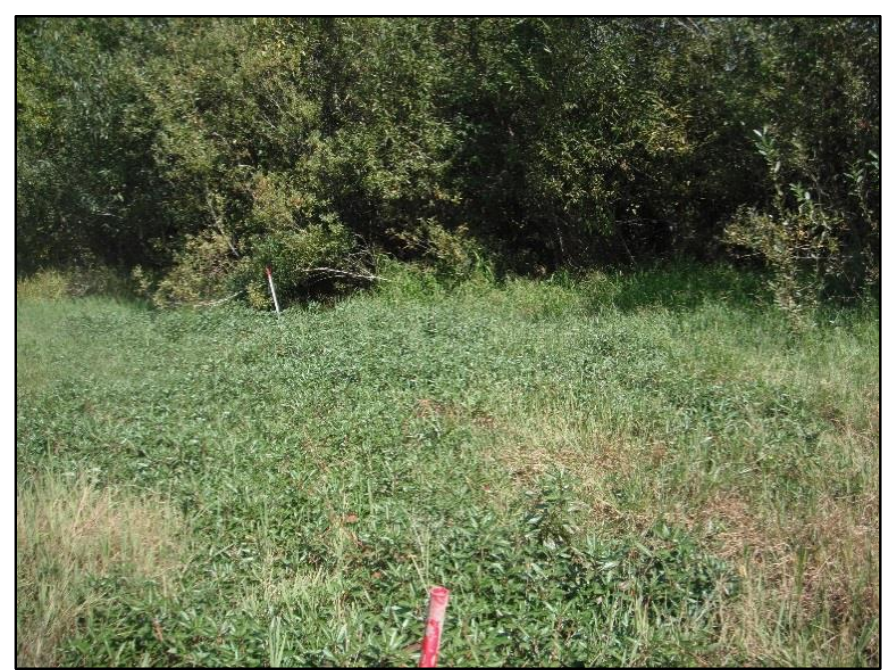

September 18, 2012

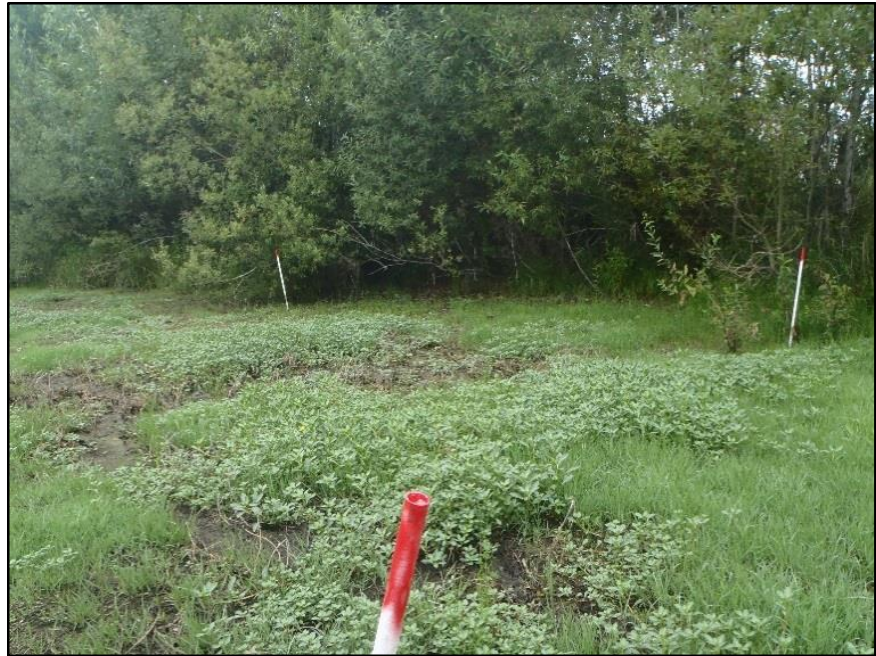

August 2, 2013

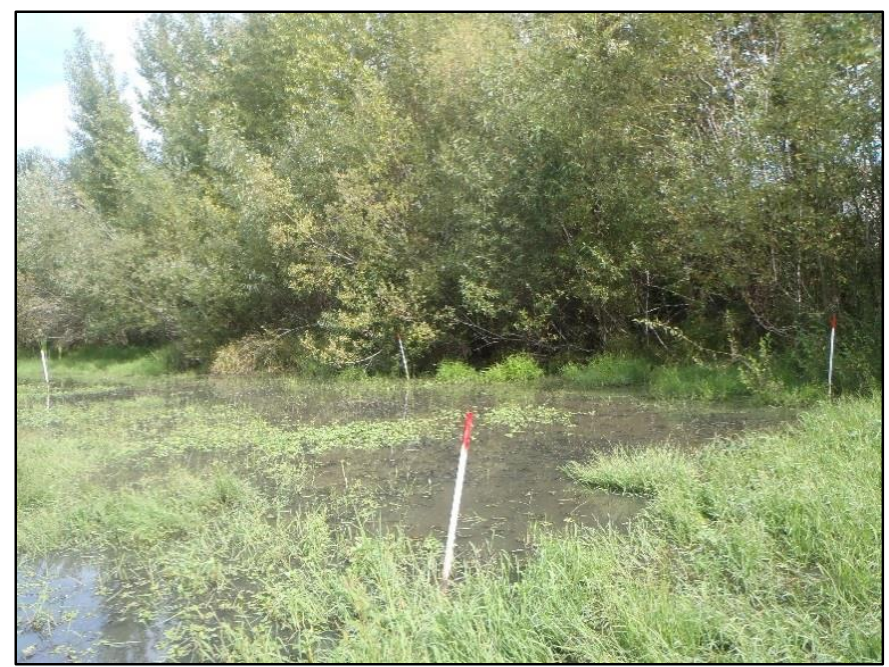

September 20, 2013

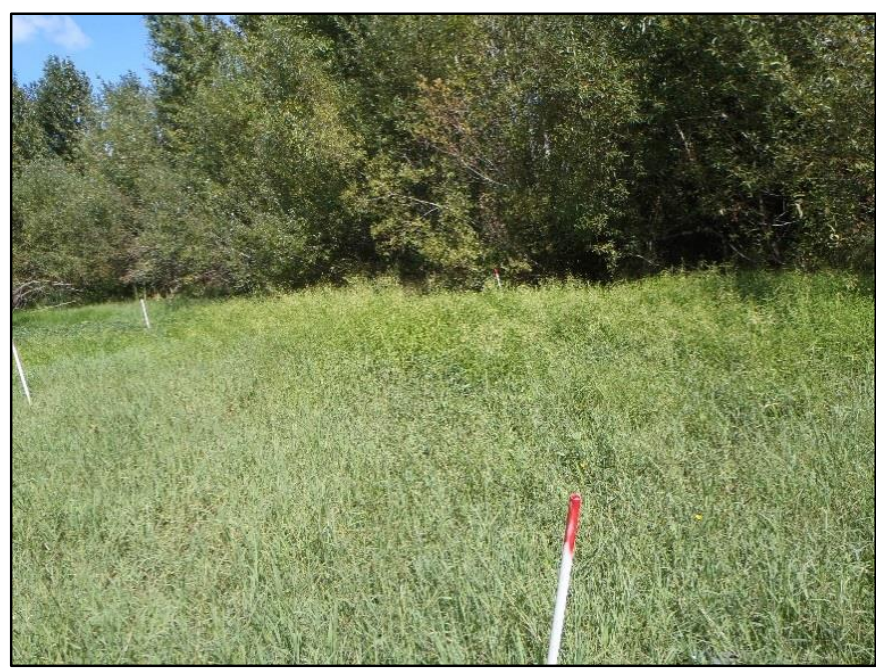

September 9, 2014 


\section{Full Chemical Application, West Pond: Control (Plot C4)}

Control plot within West Pond during duration of 3\% glyphosate application. Within the control group, emergence of $L$. peploides ssp. montevidensis early in the growing season resulted in an erect growth form by September.

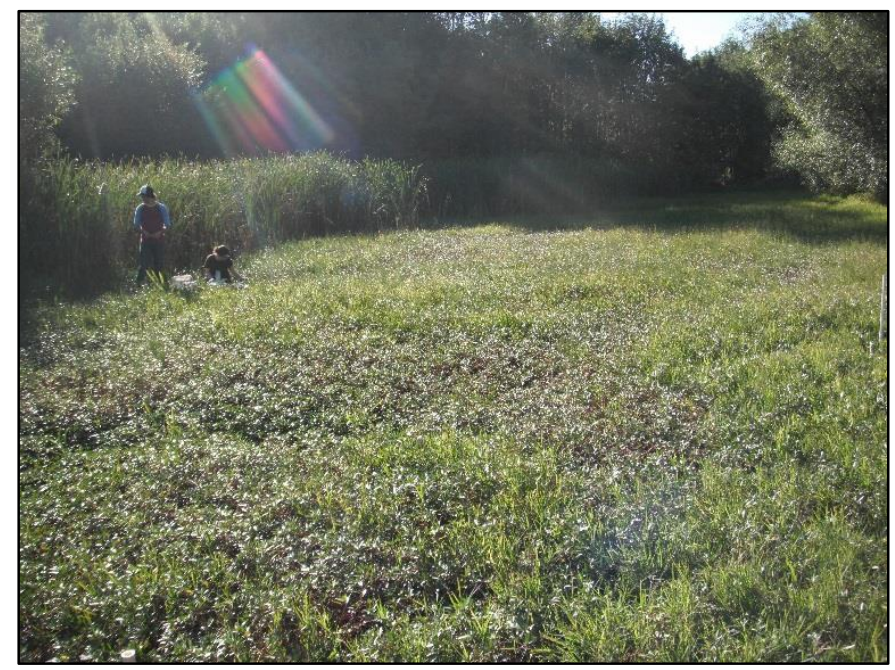

September 25, 2012

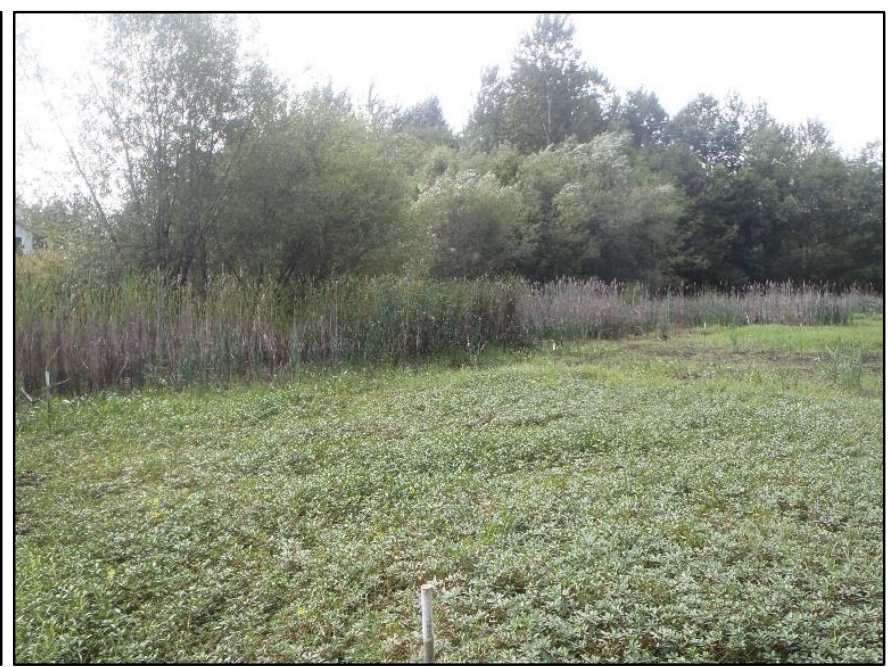

September 20, 2013

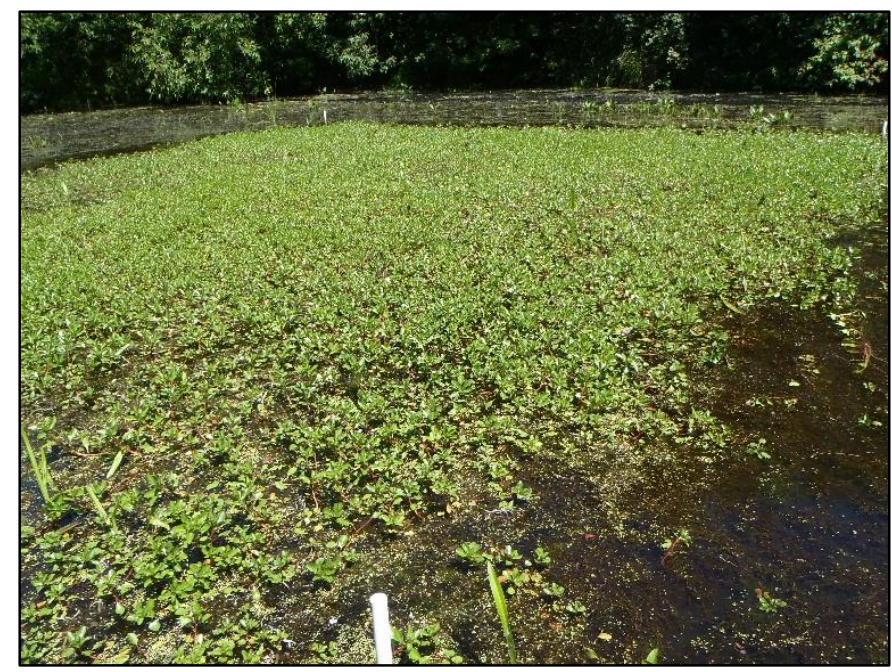

July 1, 2014 Alternate photo angle

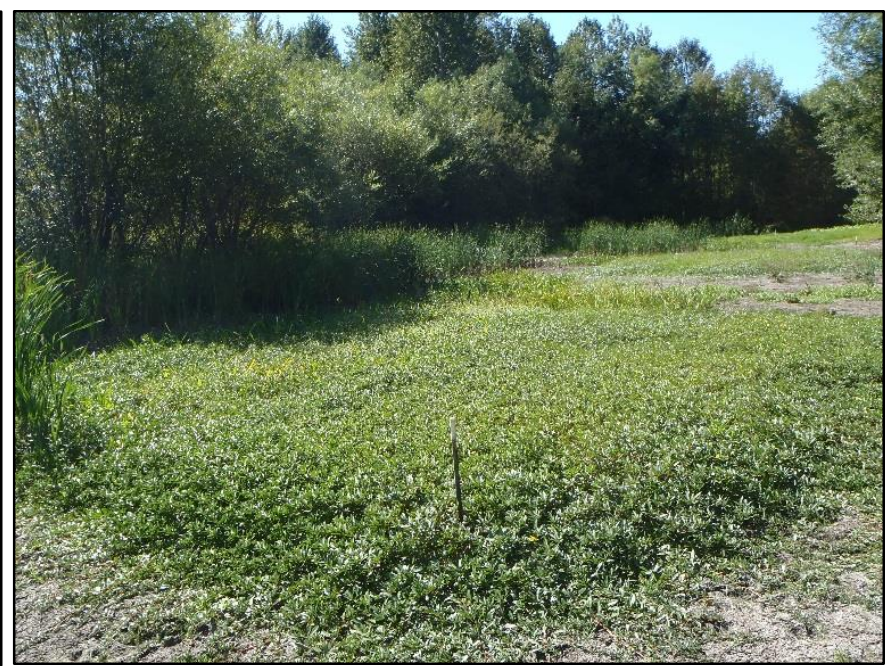

September 9, 2014 


\section{Full Chemical Application, West Pond: 3\% Glyphosate (Plot A7)}

Monitoring plot applied with 3\% glyphosate on September 26, 2012 and August 8, 2013. Minimal regrowth was observed immediately after chemical application. Yet, by September 2014, total percent cover of L. peploides ssp. montevidensis greatly increased, with the population possessing a prostrate, or creeping growth form.

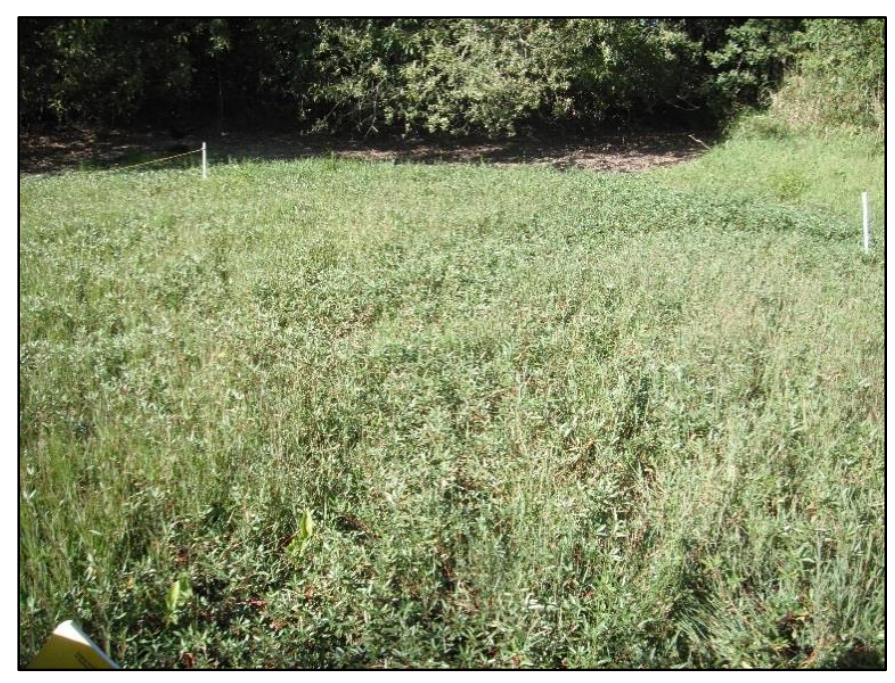

September 25, 2012

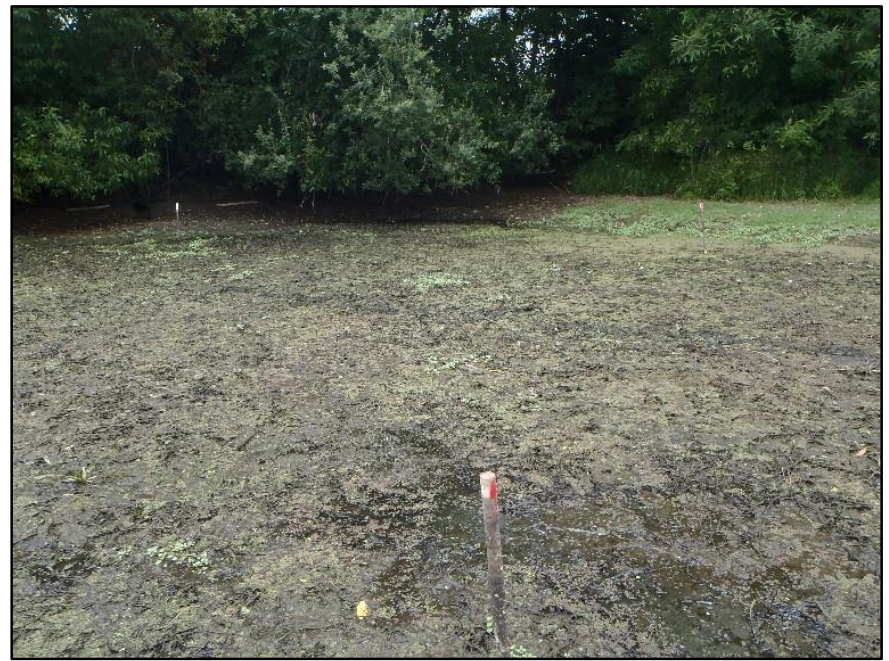

August 2, 2013

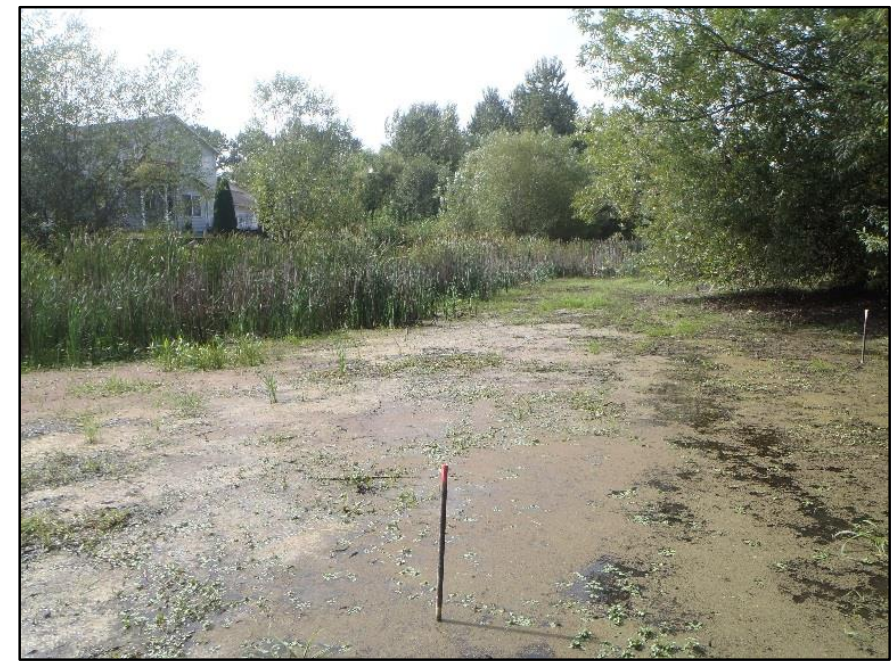

September 20, 2013 Alternate photo angle

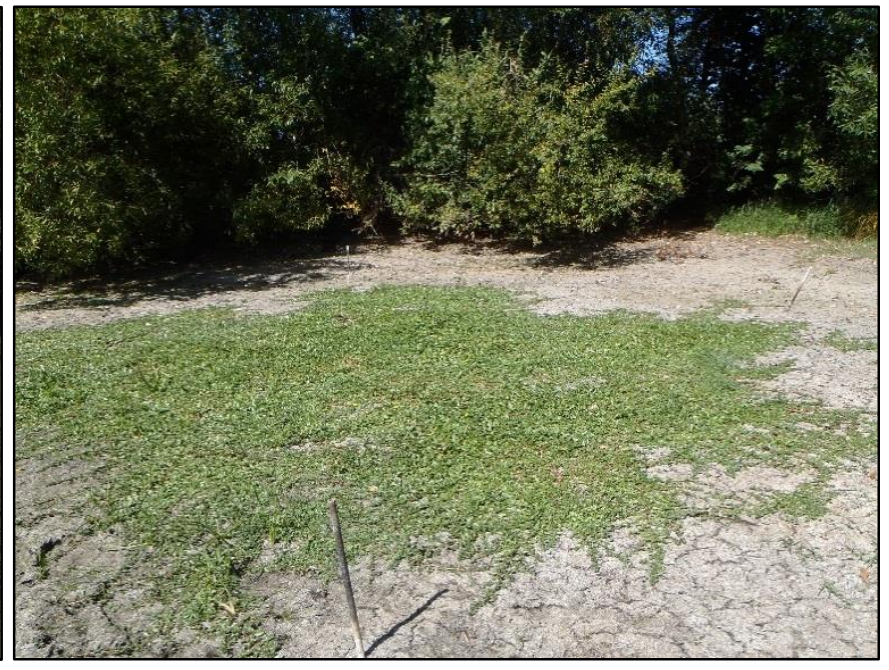

September 9, 2014 


\section{Full Chemical Application, West Pond: 3\% Glyphosate (Plot A8)}

Monitoring plot applied with 3\% glyphosate on September 26, 2012 and August 8, 2013. Compared to control plots within West Pond, minimal L. peploides ssp. montevidensis was visible in July and August 2014. By September 9, 2014, percent cover of L. peploides ssp. montevidensis was at almost 100\%. Plants within plot exhibited prostrate or creeping growth.

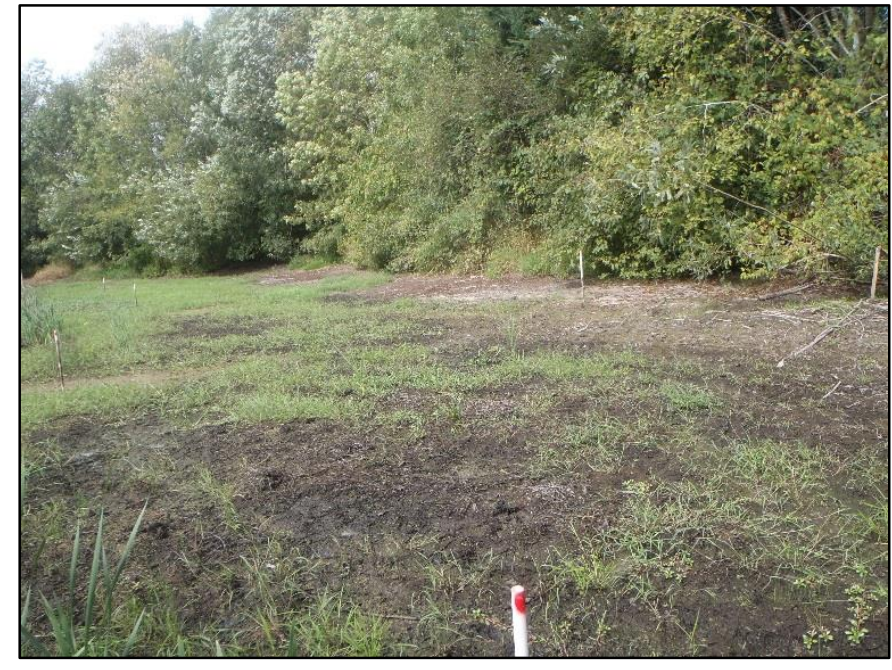

September 20, 2013

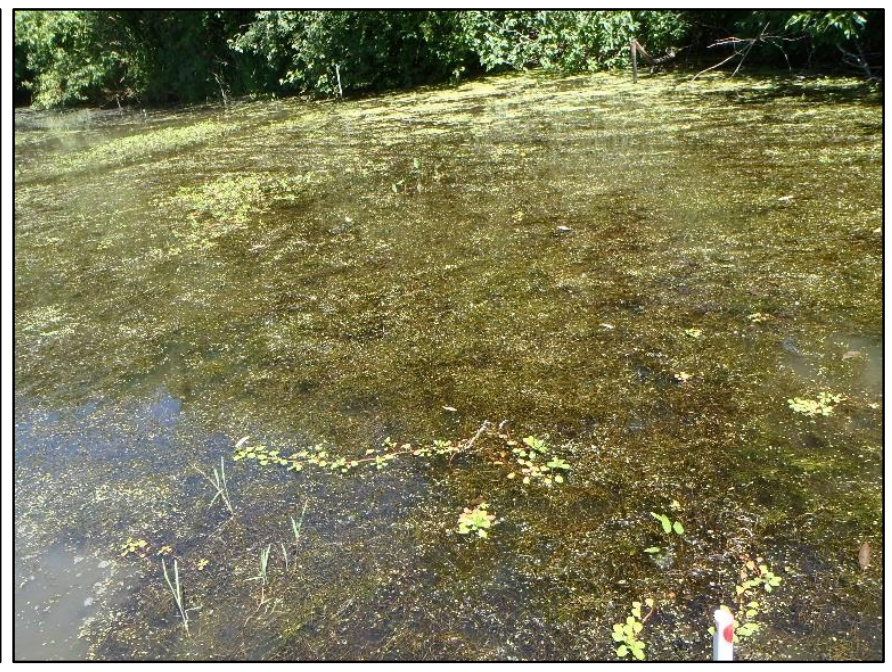

July 1, 2014

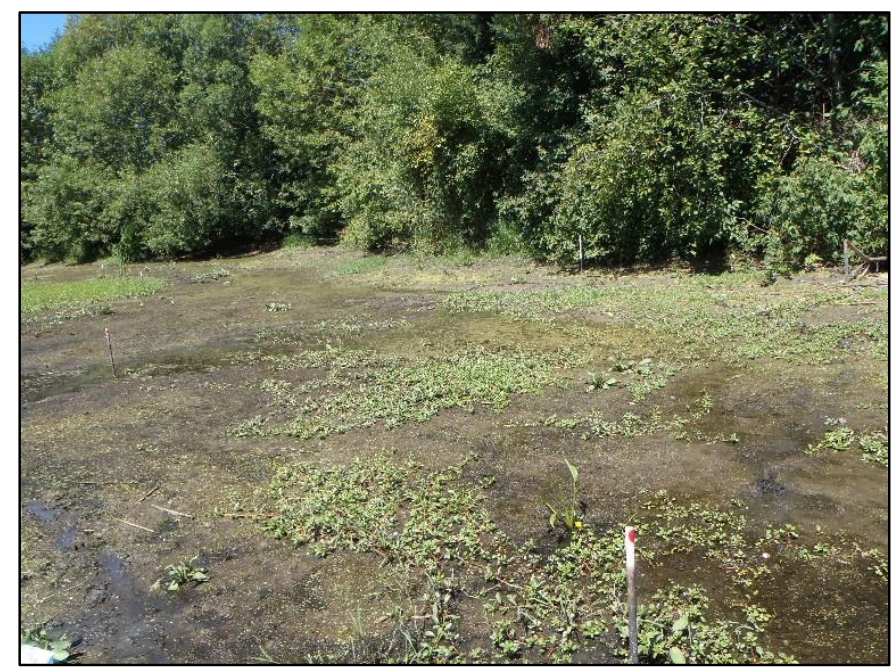

August 7, 2014

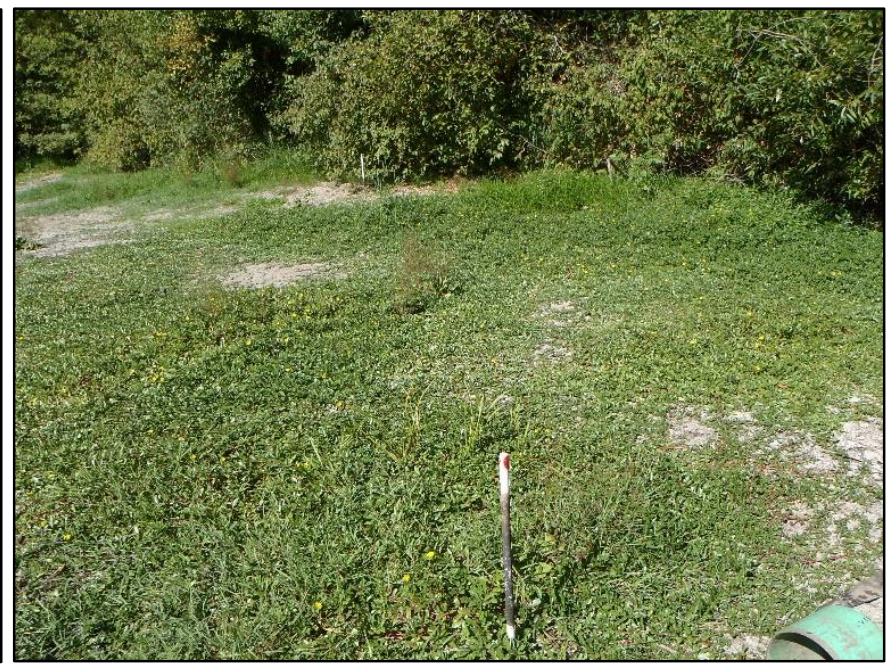

September 9, 2014 


\section{Select Monitoring Photos}

\section{West Pond (Picture Point WEWP)}

Chemical application of 3\% glyphosate on September 26, 2012 and August 8, 2014 reduced the presence of L. peploides ssp. montevidensis, created open water habitat and permitted regrowth of wetland grasses.

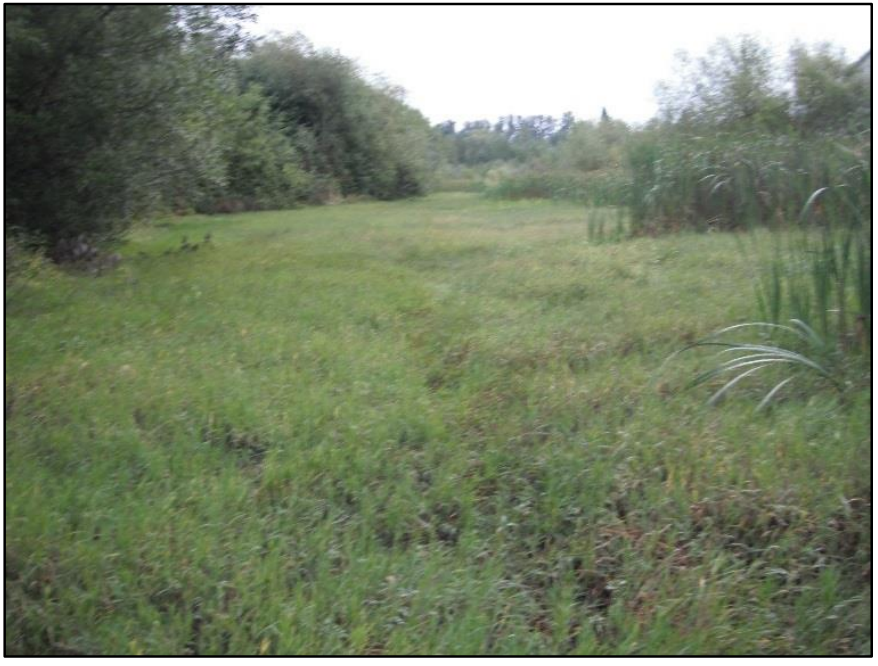

September 23, 2012

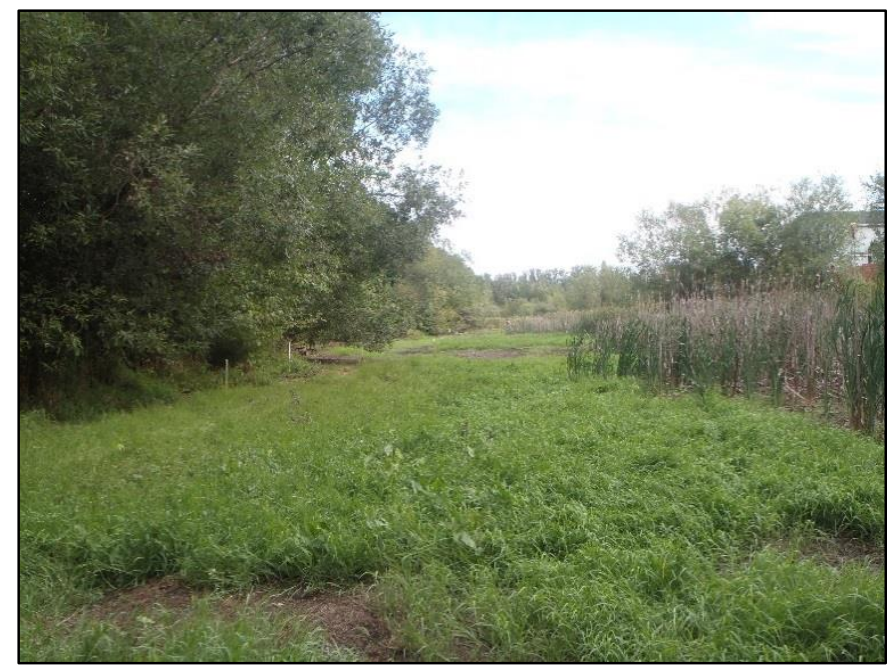

September 20, 2013

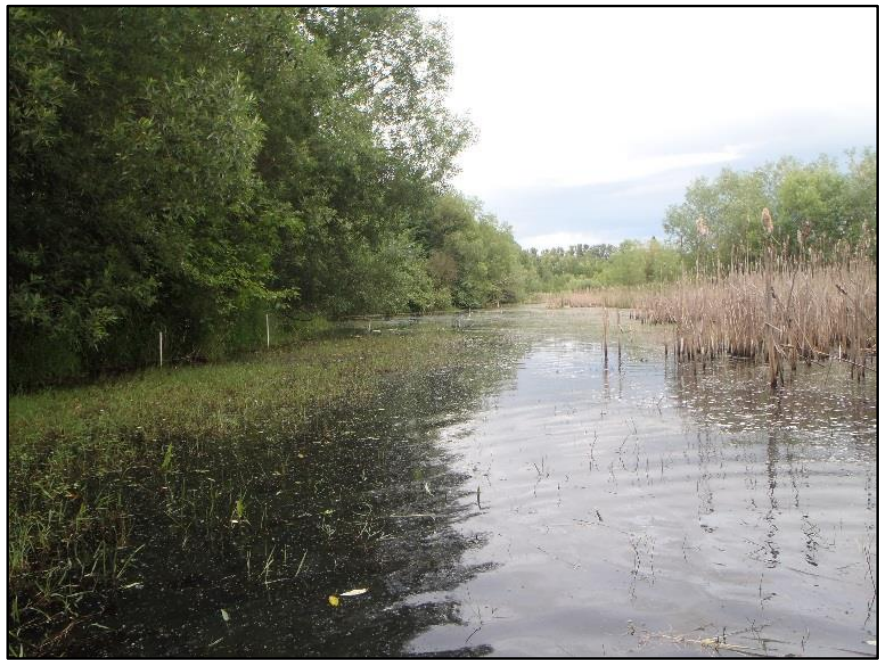

June 20, 2013

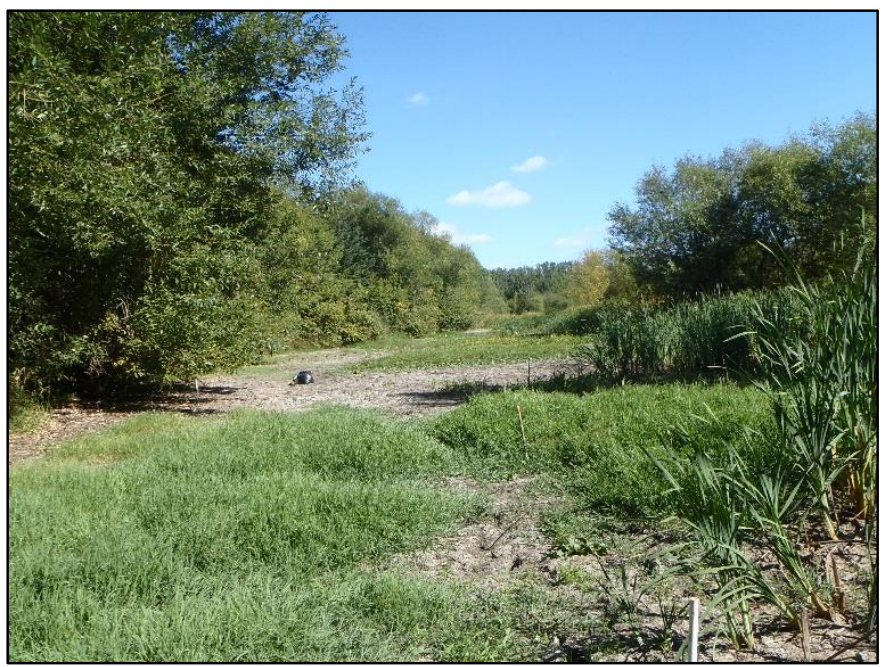

September 9, 2014 


\section{Doughnut Pond (Picture Point WEWP)}

Chemical application of 3\% glyphosate on September 26, 2012 and August 8, 2013 reduced the presence of L. peploides ssp. montevidensis, created open water habitat and permitted regrowth of wetland grasses.

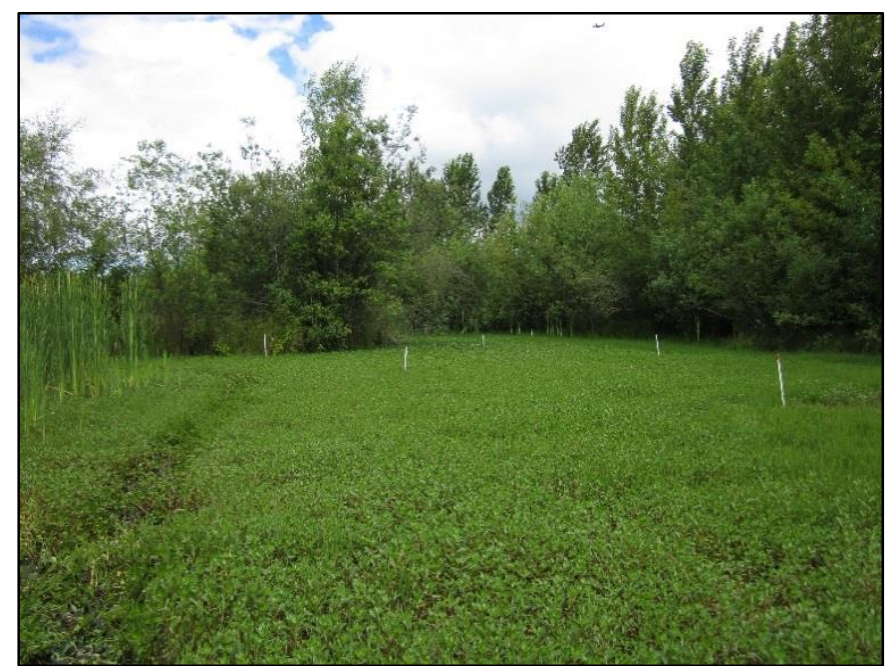

June 8,2012

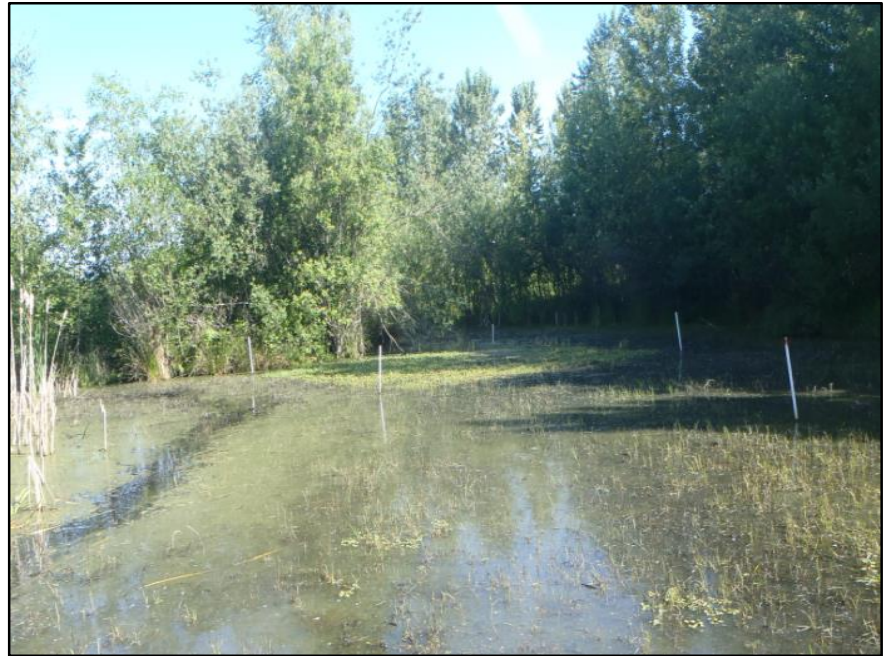

June 15, 2013

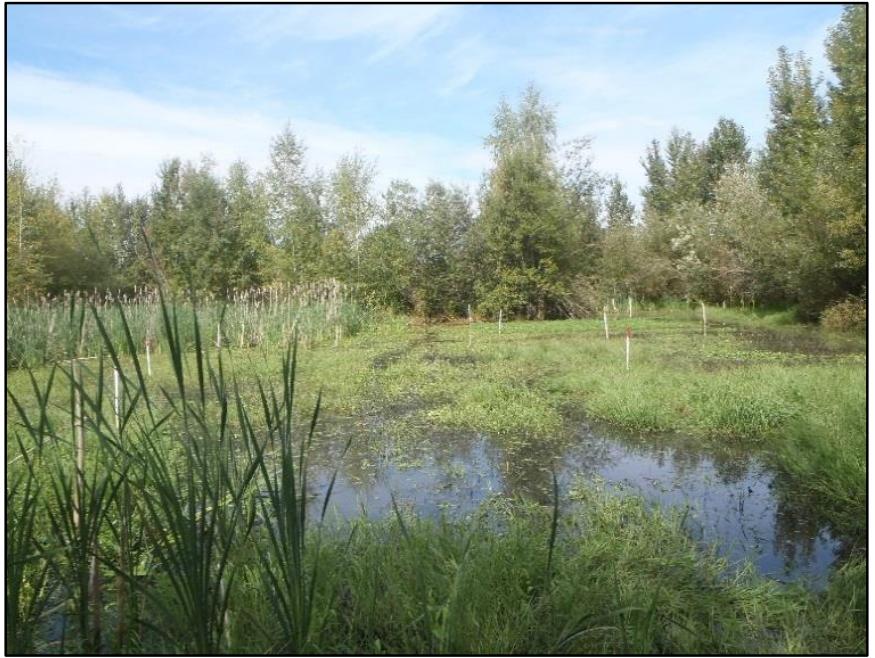

September 20, 2013

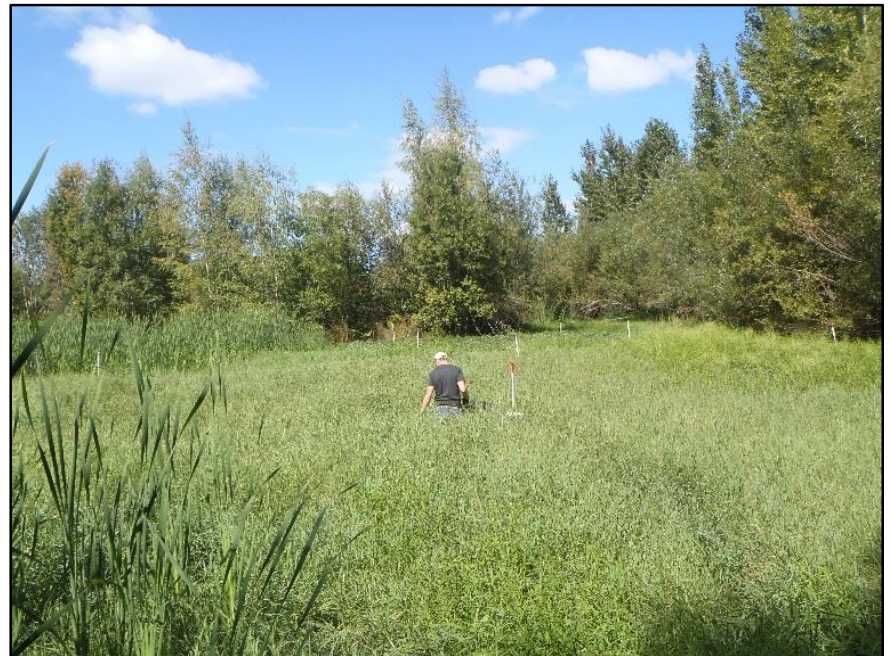

September 9, 2014 


\section{E. Scientific Presentations}

Staunch, A. Oral Presentation, "Eradication of Ludwigia peploides from a small palustrine wetland in Portland, OR: Lessons Learned." Society of Ecological Restoration Regional Meeting. Redmond, OR, October 2014.

Staunch, A. Poster Presentation, "Eradication of Ludwigia peploides from the Blue Heron Wetlands of NE Portland: Project update - September 1, 2014." Meeting the Challenge: Preventing, Detecting and Controlling Invasive Plants. Seattle, WA, September 2014.

Staunch, A. Poster Presentation, "Eradication of Ludwigia peploides from the Blue Heron Wetlands of NE Portland: Project update - May 1, 2014." Joint Aquatic Science Meeting. Portland, OR, May 2014.

Staunch, A. Oral Presentation, "Eradication of Ludwigia peploides the Blue Heron Wetlands of NE Portland, OR: Past, present and future." Aquatic Weed Workshop. Salem, OR, April 2014.

Staunch, A. Oral Presentation, "Ludwigia in the Lower Willamette: Identification, impact and control." Four County Weed Management Area Annual Meeting. Portland, OR, January 2014.

Staunch, A. Poster Presentation, "Eradication of Ludwigia peploides form the Blue Heron Wetlands of NE Portland, OR: Project Update." Urban Ecosystem Research Consortium. Portland, OR, February 2014.

Staunch, A. Poster Presentation, "Eradication of Ludwigia peploides from the Blue Heron Wetlands of NE Portland, OR." Portland State University Environmental Science and Management Research Colloquium. Portland, OR, November 2012.

Staunch, A. Poster Presentation, "Eradication of Ludwigia peploides from the Blue Heron Wetlands of NE Portland, OR." Urban Ecosystem Research Consortium. Portland, OR, February 2012. 
Final Draft: April, 2015

\section{F. Expenses by Category}

Total expenditures and in-kind matches by category of the BHWRP.

\begin{tabular}{|c|c|c|c|c|c|c|c|c|c|c|c|}
\hline \multirow[t]{2}{*}{ Activity } & \multicolumn{5}{|c|}{ Amount requested } & \multicolumn{5}{|c|}{ In-Kind Match } & \multirow[t]{2}{*}{ Total Cost } \\
\hline & 2011 & 2012 & 2013 & 2014 & All years & 2011 & 2012 & 2013 & 2014 & All years & \\
\hline \multicolumn{12}{|l|}{ Personal services } \\
\hline Project Coordinator & $\$ 1,866.61$ & $\$ 4,578.39$ & $\$ 1,892.77$ & $\$ 5,857.57$ & $\$ 14,195.34$ & & & & & & $\$ 14,195.34$ \\
\hline Administrative Fee & & & & $\$ 621.08$ & $\$ 621.08$ & & & & & & $\$ 621.08$ \\
\hline \multicolumn{12}{|l|}{ Volunteer labor } \\
\hline Calculate at $\$ 22.14 /$ hour & & & & & & $\$ 5,247.18$ & $\$ 4,549.77$ & $\$ 3,321.00$ & $\$ 4,306.23$ & $\$ 17,424.18$ & $\$ 17,424.18$ \\
\hline \multicolumn{12}{|l|}{ Professional services } \\
\hline Hand removal & & & $\$ 1,323.00$ & $\$ 4,102.00$ & $\$ 5,425.00$ & & & & & & $\$ 5,425.00$ \\
\hline Chemical Application & $\$ 210.00$ & $\$ 969.24$ & $\$ 1,239.14$ & & $\$ 2,418.38$ & & & & $\$ 1,000.00$ & $\$ 1,000.00$ & $\$ 3,418.38$ \\
\hline Educational support \& planning & & $\$ 732.55$ & & & $\$ 732.55$ & & & & & & $\$ 732.55$ \\
\hline Beaver guard installation & & & & $\$ 21.48$ & $\$ 21.48$ & & & & $\$ 1,020.00$ & $\$ 1,020.00$ & $\$ 1,041.48$ \\
\hline GIS Tech & & $\$ 288.00$ & $\$ 600.00$ & & $\$ 888.00$ & & & & & & $\$ 888.00$ \\
\hline Research Assistant & & $\$ 140.00$ & $\$ 192.00$ & $\$ 192.00$ & $\$ 524.00$ & & & & & & $\$ 524.00$ \\
\hline Professional consulting (Figure 3 ) & & & & & & $\$ 5,110.97$ & $\$ 4,970.86$ & $\$ 4,837.19$ & $\$ 3,796.30$ & $\$ 18,297.12$ & $\$ 18,297.12$ \\
\hline \multicolumn{12}{|l|}{ Plants and Seeds } \\
\hline Plants & & $\$ 451.00$ & $\$ 944.50$ & $\$ 1,860.00$ & $\$ 3,255.50$ & & & & & & $\$ 3,255.50$ \\
\hline Seeds & & & $\$ 890.75$ & $\$ 890.75$ & $\$ 1,781.50$ & & & & & & $\$ 1,781.50$ \\
\hline \multicolumn{12}{|l|}{ Materials \& supplies } \\
\hline Test plot supplies & $\$ 170.59$ & $\$ 44.53$ & $\$ 170.51$ & $\$ 18.47$ & $\$ 404.10$ & & & & & & $\$ 404.10$ \\
\hline Volunteer event supplies & & $\$ 118.50$ & $\$ 118.98$ & $\$ 349.87$ & $\$ 587.35$ & & & & & & $\$ 587.35$ \\
\hline Printing materials and signage & $\$ 245.00$ & $\$ 591.26$ & $\$ 103.31$ & $\$ 241.93$ & $\$ 1,181.50$ & & & & & & $\$ 1,181.50$ \\
\hline Tools & & & $\$ 475.71$ & $\$ 297.60$ & $\$ 773.31$ & & & & & & $\$ 773.31$ \\
\hline Miscellaneous & & $\$ 73.69$ & $\$ 110.00$ & $\$ 199.85$ & $\$ 383.54$ & & & & & & $\$ 383.54$ \\
\hline \multicolumn{12}{|l|}{ Indirect of overhead costs } \\
\hline Office Space at Kenton Firehouse & & & & & & $\$ 300.00$ & $\$ 600.00$ & $\$ 600.00$ & $\$ 600.00$ & $\$ 2,100.00$ & $\$ 2,100.00$ \\
\hline Insurance & & & & & & $\$ 500.00$ & $\$ 1,000.00$ & $\$ 1,000.00$ & $\$ 1,000.00$ & $\$ 3,500.00$ & $\$ 3,500.00$ \\
\hline Total & $\$ 2,492.20$ & $\$ 7,987.16$ & $\$ 8,060.67$ & $\$ 14,652.60$ & $33,192.63$ & $\$ 11,158.15$ & $\$ 11,120.63$ & $\$ 9,758.19$ & $\$ 11,722.53$ & $\$ 43,341.30$ & $\$ 76,533.93$ \\
\hline
\end{tabular}




\section{G. Common Open Space Agreement}

(City of Portland, 1997)

\section{EXHBITE}

Date:

After Recording Return

Original To:

After Recording Return

Copy To:

Current Planning

Bureau of Planning

1120 S.W. 5th Ave., Rm. 1002

Special Inspections

1120 S.W. Sth Ave.,

Bureau of Buildings

P.O. Box 8120

File No. LUR 96-686

Portland, OR. 97207

\section{DECLARATION OF \\ COMMON OPEN SPACE \\ MAINTENANCE AGREEMENT}

Declarants are the owners of the following parcels and Declarants hereby declare as follows:

\section{PURPOSE OF AGREEMENT.}

The purpose of this agreement is to provide for the construction and perpetual maintenance of the common open space by the owners of the parcels of property described in section 2 of this agreement.

2. LEGAL DESCRIPTION.

a. The common open space is as follows:

Tract "A" as shown on the plat of the Blue Heron Meadows Subdivision.

b. The owners of lots 1 through 104 of the Blue Heron Meadows Subdivision shall jointly own the common open space.

\section{DURATION AND NATURE OF AGREEMENT.}

This agreement shall continue in perpetuity. This agreement is intended to and does attach to and run with the land affected herein. This agreement is binding on the undersigned landowner, Pacific Western Homes, Inc., and all persons claiming under it. It is the intent of Pacific Western Homes, Inc. to create a continuing obligation and right on the part of Pacific Western Homes, Inc. and subsequent owners of the subject land. 


\section{CONSTRUCTION OF IMPROVEMENTS.}

\section{Landscaping:}

Pacific Western Homes, Inc. shall install any required landscaping and construct the improvements at Pacific Western Homes Inc. expense.

\section{Access \& Lighting:}

a. Access into the wetland (common open space) from individual lots shall be prohibited.

b. Outdoor lights shall be mounted or shielded so that light does not shine into the wetland (common open space).

\section{OWNERSHIP.}

Pacific Western Homes, Inc. is the owner of the common open space. As Pacific Western Homes, Inc. transfers each of the lots in the subdivision to subsequent purchasers, each such purchaser shall acquire an undivided ownership interest in the common open space. When Pacific Western Homes, Inc. has conveyed all of the lots in the subdivision to others, Pacific Western Homes, Inc. ownership interest shall terminate.

\section{MAINTENANCE.}

The owners of each lot shall be jointly and equally responsible for the maintenance of the common open space. If, however, the act of an owner or guest, invitee, licensee, contractor, or agent of an owner causes damage, the owner shall be responsible for the entire cost of the repair.

The owners shall be responsible for maintaining the open space including the improvements, pathways, landscaping, trees and natural vegetation in a continuously safe condition. Maintenance shall include but not be limited to:

1. The removal of debris, leaves, ice and snow from pedestrianways and bikeways, and maintenance of the clearspace above and adjoining them;

2. The removal of trash or dangerous materials;

3. The trimming of trees and vegetation along the right-of-way areas;

4. The replanting of any areas having exposed soil due to an earth slide or the removal of vegetation; 
5. The maintenance of the improvements in a usable condition and in good repair.

No improvements, plantings or other materials which would interfere with the maintenance or operation of the storm sewer, sanitary sewer or water lines shall be placed over the lines. Landscaping having a root system which will not damage the pipes may be placed on the easement and the replacement of landscaping shall be included in the cost of any maintenance work.

\section{INDEMINIFICATION.}

The owners of the common open space area and the improvements shall hold harmless, defend and indemnify the City of Portland and the City's officers, agents, and employees against all claims, demands, actions, and suits, including attorney's fees and costs brought against any of them arising out of the failure to properly design, locate, construct, or maintain the common open space and improvements which are subject to this agreement.

All workers undertaking maintenance work on the improvements within the common open space shall have standard liability insurance in a reasonable amount from a reputable insurance company which protects each owner.

Each of the owners of the common open space and improvements shall release and indemnify the others against all liability for injury to an owner, member of the owner's family or resident of an owner's home for injury or for property damage when it results from any undertaking pursuant to this agreement.

\section{ADDITIONALLX CREATED LOTS.}

In the event that any additional lots are created from the existing properties as a result of legal divisions of lots within the subdivision, the owner of the newly created lots shall possess an undivided interest in the common open space and improvements and shall participate in and be equally bound by this agreement.

\section{MAINTENANCE OBLIGATIONS AND ARBITRATION.}

The owners of the common opens space and improvements shall confer from time to time regarding performance of required maintenance under this agreement. Each lot shall have one vote. Where there is more than one owner of a lot, each owner shall have a proportional share of one vote. In the event of a disagreement concerning maintenance obligations and payment, the owners shall agree upon an arbitrator who shall resolve such disagreement. If the owners cannot agree on an arbitrator, the presiding judge of the Circuit Court of the State of Oregon for the County of Multnomah shall appoint an arbitrator. The decision of the arbitrator shall be binding on the owners and the fee of the arbitrator shall be borne equally by the owners. 
Any notice, demand, or report required under this agreement shall be sent to each owner in care of the street address of his parcel, or in the event the owner does not reside on the said property, in care of the current property tax notification address of the property; provided, however, that an owner can change their notification address by written notice to each other owner. Any required notice or demand shall be made by hand delivery or certified mail, and shall be deemed received on actual receipt or 48 hours after being mailed, whichever first occurs.

\section{TERMINATION.}

The owners may not withdraw from, amend or dissolve this agreement without the written approval of the City of Portland. If this agreement is a condition of the approval of a division of property, the City of Portland may require such condition to be modified before permitting this agreement to be dissolved or permitting a party to withdraw from this agreement.

11. RELEASE.

At such time as the common open space is accepted by Council action for maintenance by the City of Portland, the owners will be released from their maintenance obligation and from all other obligations under this agreement for the common open space improvements accepted by the City.

IN WITNESS WHEREOF, the parties hereto have executed this Maintenance Agreement on OCtober $3,1997$.

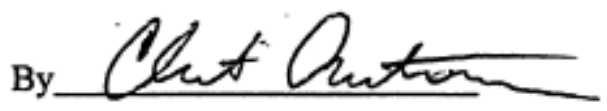

\section{MUST BE NOTARIZED}

SUBSCRIBED AND SWORN TO before me this $3^{\text {red }}$ day of Qctober, 1997
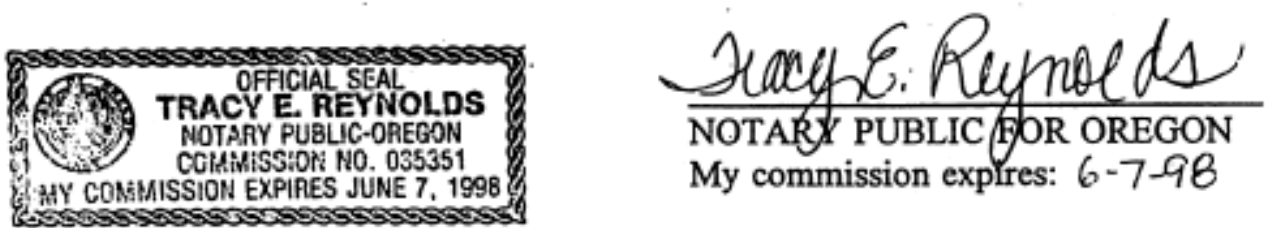